$1-2013$

\title{
Summaries of Twenty Cases of Successful Private Antitrust Enforcement
}

Joshua P. Davis

University of San Francisco, davisj@usfca.edu

Robert H. Lande

University of Baltimore School of Law, rlande@ubalt.edu

Follow this and additional works at: http://scholarworks.law.ubalt.edu/all_fac

Part of the Antitrust and Trade Regulation Commons

\section{Recommended Citation}

Summaries of Twenty Cases of Successful Private Antitrust Enforcement, Univ. of San Francisco Law Research Paper No. 2013-01

This Article is brought to you for free and open access by the Faculty Scholarship at ScholarWorks@University of Baltimore School of Law. It has been accepted for inclusion in All Faculty Scholarship by an authorized administrator of ScholarWorks@University of Baltimore School of Law. For more information, please contact snolan@ubalt.edu. 


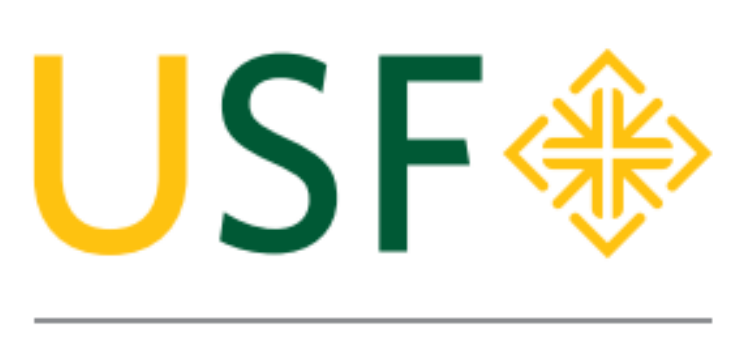

\section{School of Law}

\section{University of San Francisco School of Law}

University of San Francisco Law Research Paper No. 2013-01

Summaries of Twenty Cases of Successful Private Antitrust ENFORCEMENT

Joshua P. Davis \& Robert H. Lande 


\title{
SuMMARIES OF TWENTY CASES OF SUCCESSFUL PRIVATE ANTITRUST ENFORCEMENT
}

\author{
Joshua P. Davis \& Robert H. Lande ${ }^{1}$
}

\section{Table of Contents}

1.\# 3M (Meijer, Inc. v. 3M) ......................................................................... 3\#

2.\# Air Cargo Shipping Services Antitrust Litigation .............................................. 7\#

3.\# De Beers (Sullivan v. DB Investments, Inc.)................................................ 11\#

4.\# Electrical Carbon Products Antitrust Litigation ............................................ 15\#

5.\# Ethylene Propylene Diene Monomer Antitrust Litigation .............................. 21\#

6.\# High Pressure Laminates Antitrust Litigation ............................................... 24\#

7.\# Intel Corp. Microprocessor Antitrust Litigation............................................. 27\#

8.\# Polyester Staple Antitrust Litigation............................................................... 31\#

9.\# Molecular Diagnostics Labs. v. Hoffmann-La Roche Inc.............................. 40\#

10.\# Methionine Antitrust Litigation........................................................... 44\#

11.\# MSG (Monosodium Glutamate Antitrust Litigation) ................................. 47\#

12.\# Mylan (In re Lorazepam \& Clorazepate Antitrust Litigation).................... 50\#

13.\# Novell v. Microsoft............................................................................... 54\#

14.\# Ortho Biotech Products, L.P. v. Amgen, Inc........................................... 57\#

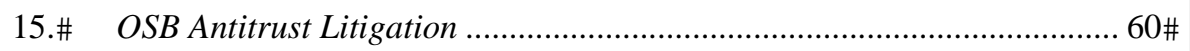

16.\# Scrap Metal Antitrust Litigation ................................................................. 63\#

17.\# Tobacco (DeLoach v. Philip Morris Cos.).............................................. 70\#

18.\# Tricor Antitrust Litigation..................................................................... $75 \#$

19.\# Visa (United States v. Visa USA) .......................................................... 80\#

20.\# Warfarin Sodium Antitrust Litigation (Warfarin Sodium II) .................... 86\#

\footnotetext{
${ }^{1}$ The authors are, respectively, Associate Dean for Faculty Scholarship and Professor of Law, University of San Francisco School of Law, and member of the Advisory Board of the American Antitrust Institute; and Venable Professor of Law, University of Baltimore School of Law, and Director, American Antitrust Institute. The authors are grateful to the American Antitrust Institute for funding the original empirical research that is analyzed in this article and to Kathi Black, W. James Denvil, Caitlin May, Erik Shallman, and Gary Stapleton for valuable research assistance.
}

CDavis \& Lande: This paper is a draft and subject to amendment. 


\title{
SYNOPSIS
}

\begin{abstract}
This document summarizes twenty cases of successful private antitrust enforcement. These twenty summaries build on earlier summaries of forty additional cases of successful private enforcement available at http://ssrn.com/abstract=1105523. An analysis of the data from the original forty cases is available at http://ssrn.com/abstract=1090661 (published as Robert L. Lande and Joshua P. Davis, Benefits From Private Antitrust Enforcement: An Analysis of Forty Cases, 42 U.S.F. L. REV. 879 (2008)) and an argument based on the forty cases that private antitrust enforcement probably has greater deterrence effects than criminal enforcement by the Department of Justice is available at http://ssrn.com/abstract=1565693 (published as Robert L. Lande and Joshua P. Davis, Comparative Deterrence from Private Enforcement and Criminal Enforcement of the U.S. Antitrust Laws, 2011 B.Y.U. L. REV. 315).
\end{abstract}

CDavis \& Lande: This paper is a draft and subject to amendment. 


\section{1. $3 M(M e i j e r, \text { Inc. v. } 3 M)^{1}$}

This case is notable because: (1) the plaintiffs recovered \$136 million; (2) the class plaintiffs in the Bradburn action received a total in damages of $\$ 39,750,000$; (3) the plaintiffs' attorneys in the Bradburn action were awarded $\$ 14,569,893$ for fees, costs, and expenses they incurred (overall 37\%); (4) the class plaintiffs in the Meijer action received a total in damages of $\$ 27,783,836.97$; (5) the plaintiffs' attorneys in the Meijer action were awarded $\$ 7,890,452.46$ for fees, costs, and expenses they incurred (overall 27.4\%).

\section{A. LePage's, Inc. v. 3M}

The anticompetitive conduct of 3M that formed the basis of the Meijer class action suit was the subject of a prior lawsuit, LePage's Inc. v 3M, Civ. A. No. 97-3983, 2000 U.S. Dist. LEXIS 3087 (E.D Pa. Mar. 14, 200). In that lawsuit, a competing supplier of transparent tape, LePage's Inc. (LePage's) brought suit alleging that 3M unlawfully maintained monopoly power in violation of Section 2 of the Sherman Act, 15 U.S.C §2. After a three week trial, the jury found in favor of LePage's on its unlawful maintenance of monopoly power claim. The jury awarded damages in the amount of $\$ 22,828,899$, which was later trebled to $\$ 68,486,697$. $^{2}$

$3 \mathrm{M}$ filed a motion for judgment as a matter of law. That motion was granted in part for the claim of "attempted maintenance of monopoly power," which was not supported statutorily. The motion was denied in all other aspects. ${ }^{3}$ 3M appealed this decision. Originally the Third Circuit Court of Appeals reversed the trial court's ruling, but, after rehearing en banc, the court reinstated the jury verdict. ${ }^{4}$

\section{B. Bradburn Parent/Teacher Store Inc. v. 3M}

Thereafter, Bradburn Parent/Teacher Store Inc. (Bradburn) brought a class action lawsuit against 3M. The complaint alleged that 3M's bundled rebate programs and exclusive dealing agreements with various retailers created a monopoly in the transparent tape market in violation of Section 2 of the Sherman Act, 15 U.S. C. $\S 2 .^{5}$ The judge overseeing the case was the Honorable John R. Padova, who was nominated by George H.W. Bush in 1991.

Bradburn first sought to represent a class that included Meijer, but was ultimately only granted class certification as a modified class that excluded purchases of private label tape, such as Meijer. ${ }^{6}$ Meijer then attempted to intervene as an additional class representative. ${ }^{7}$ The trial court denied the motion, ${ }^{8}$ then upon motion for reconsideration denied the motion due to the untimeliness of the filing of the motion and the undue delay it would cause. ${ }^{9}$ The court noted

${ }^{1}$ C.A. No. 04-5871 (E.D. Pa. 2003)

${ }^{2}$ See Le Page’s Inc. v. 3M Company, C.A. No. 97-3983, 2000 WL 280350 (E.D. Pa. Mar.14, 2000), aff'd, 324 F.3d

141 (3d Cir. 2003) (en banc), cert. denied, 542 U.S. 953 (2004).

${ }^{3}$ Id. at *1.

${ }^{4}$ Id.; see also Le Page's, Inc. v. 3M, 324 F.3d 141 (3d Cir. 2003).

${ }^{5}$ Bradburn Parent/Teacher Store Inc. v. 3M, C.A. 02-7676, 2004 WL 1842987, *1 (E.D. Pa. 2004).

${ }^{6} I d$.

${ }^{7}$ Bradburn Parent/Teacher Store Inc. v. 3M, C.A. 02-7676, Meijer, Inc. and Meijer Distribution Inc.'s Motion to Intervene, 9/20/2004.

${ }^{8}$ Bradburn Parent/Teacher Store Inc. v. 3M, C.A. 02-7676, Order Denying Meijer Inc.'s Motion to Intervene, 10/28/2004.

${ }^{9}$ Bradburn Parent/Teacher Store, Inc. v. 3M, Civ. A. No. 02-7676, 2004 WL 2900810 (E.D. Pa. Dec. 10, 2004).

CDavis \& Lande: This paper is a draft and subject to amendment. 
that "there is nothing which would prevent Meijer from filing its own individual or class-action lawsuit against [3M] and presenting its claims in that forum."

Bradburn sought to apply estoppel to a number of the liability findings of the Le Page jury and the court granted collateral estoppel on several issues on March 30, 2005 . $^{11}$ The court denied a portion of 3M's motion for reconsideration, finding, among other things, that " $3 \mathrm{M}$ possessed monopoly power in the relevant market, including the power to control prices and exclude competition in the relevant market." Additionally the court also deemed that " $3 \mathrm{M}$ willfully maintained such monopoly power by predatory or exclusionary conduct.”12 3M moved for an interlocutory appeal, which was certified by the District Court, but the Third Circuit denied 3M's petition.

After the class certification and estoppel proceedings the parties proceeded with discovery, including dozens of depositions and over 1 million pages of documents. The trial was scheduled to begin on May 30, 2006, but the parties reached a settlement agreement after mediation on May 5, 2006. ${ }^{13}$

The settlement agreement provided that $\$ 39,750,000.00$ in cash would be paid into a common fund. This proposed settlement amount provided approximately 41 to 48 percent of the damages calculated by the Plaintiff's expert, which the court noted is significantly above the typical antitrust settlement. ${ }^{14}$ The court approved a reimbursement of expenses from the fund amounting to $\$ 1,011,375$. Additionally, they approved the requested attorneys' fees of $35 \%$ of the fund (or \$13,558,518) and a \$75,000 incentive award for Bradburn. ${ }^{15}$

\section{Meijer v. 3M}

\section{i. Preliminary Proceedings}

On December 16, 2004, Meijer filed its own complaint against 3M alleging possession of a monopoly in the invisible and transparent tape market in the United States. Meijer brought action on behalf of itself and other members of a class, which included persons and entitles who purchased invisible or transparent tape directly from 3M at any time from October 2, 1998 to February 10, 2006 and also purchased, for resale under their own label, "private label” invisible or transparent tape from 3M at any time from October 2, 1998 to February 10, 2006. Meijer alleged one count of monopolization in violation of Section 2 of the Sherman Act, 15 U.S.C. § 2, claiming that 3M unlawfully maintained monopoly power in the transparent tape market through its bundled rebate programs and through exclusive dealing arrangements with other retailers. ${ }^{16}$ The bundled rebate program provided purchasers with significant discounts on 3M's products through bundled rebates; however, the availability and size of the rebates were dependent upon purchasers buying products from 3M from multiple product lines. Meijer further claims that "3M has used its unlawful monopoly power . . . to harm Plaintiffs and the other Class members

${ }^{10} \mathrm{Id}$. at $* 6$

${ }^{11}$ Order Granting Final Approval of Settlement, Bradburn Parent/Teach Store, Inc. v. 3M, Civ A. No. 02-7676, 513

F. Supp. 322, 325 (E.D. Pa. May 14, 2007).

${ }^{12}$ Id.

${ }^{13}$ Id. at 326.

${ }^{14}$ Id. at 334 .

${ }^{15} \mathrm{Id}$. at 342.

${ }^{16}$ Meijer v. 3 M Company, C.A. No. 04-5871, Class Action Complaint, ๆ 27, 12/16/2004 (E.D. Pa. 2004).

CDavis \& Lande: This paper is a draft and subject to amendment. 
in their business or property by increasing, maintaining, or stabilizing the prices they paid for invisible and transparent tape above competitive levels." ${ }^{17}$

On February 10, 2005, 3M moved to dismiss the Complaint on the grounds that it was barred by the statute of limitations and failed to allege an antitrust injury. ${ }^{18}$ On July 13, 2005, the United States District Court for the Eastern District of Pennsylvania denied 3M's Motion to Dismiss, but left open the question of whether and to what extent the statute of limitations should be tolled. ${ }^{19}$

On May 26, 2005, 3M moved for coordination of pretrial discovery among the four pending actions. Individual lawsuits had been filed against 3M by Publix Supermarkets, Inc. ("Publix"), a former member of the Bradburn class, and by Kmart Corporation ("Kmart”), a member of the proposed Meijer Class. ${ }^{20}$ On June 13, 2005, Meijer agreed to such coordination. ${ }^{21}$ On July 20, 2005, the Court issued an Order that had all parties work together in good faith for coordinating pretrial discovery. ${ }^{22}$ On August 2, 2005 3M filed its Answer to Meijer's Complaint with affirmative defenses. ${ }^{23}$ On September 6, 2005 Meijer moved for class certification of a proposed class. $^{24}$

\section{ii. Settlement}

On September 26, 2005, the Court suggested following a status hearing that the parties in the coordinated actions attempt to reach a settlement through mediation. Mediation occurred on November 8 and 9, 2005. Negotiations continued in the following days, ultimately resulting in a Memorandum of Understanding, dated November 21, 2005, that resolved the Meijer, Publix, and Kmart actions. Pursuant to the Memorandum of Understanding, 3M agreed to pay a total of approximately \$30 million dollars to settle the three separate lawsuits. Meijer, Publix, and Kmart then allocated that lump sum among the three actions in proportion to the relevant purchases of 3M tape represented in each action. After the execution of the Memorandum of Understanding, Meijer's counsel spent three months negotiating the details of the formal Settlement Agreement, which the parties signed on February 10, 2006. ${ }^{25}$

On February 13, 2006, Meijer moved for preliminary approval of the settlement; on February 15, 2006, Bradburn moved to intervene for the purpose of opposing preliminary

\footnotetext{
${ }^{17}$ Meijer v. 3M Company, C.A. No. 04-5871, Class Action Complaint, 12/16/2004 (E.D. Pa. 2004).

${ }^{18}$ Meijer v. 3M Company, C.A. No. 04-5871, 3M's Motion to Dismiss, 2/10/2005; Meijer v. 3M Company, C.A. No. 04-5871, Memorandum in Support of Motion to Dismiss by 3M, 3/22/2005.

${ }^{19}$ See Meijer, Inc. v. 3M, Civ. A. No. 04-5871, 2005 WL 1660188, at *4 n.2 (E.D. Pa. July 13, 2005).

${ }^{20}$ Meijer, Inc. v. 3M, C.A. No. 04-5871, Motion for Coordination of Pre-Trial Discovery, 5/26/2005 (E.D. Pen. 2004).

${ }^{21}$ Meijer, Inc. v. 3M, C.A. No. 04-5871, Meijer's Memorandum in Response to 3M's Motion for Coordination of Pre-Trial Discovery, 6/13/2005 (E.D. Pen. 2004).

${ }^{22}$ Meijer Inc. v. 3M, C.A. No. 04-5871, Order re Coordination of Discover, 7/20/2005 (E.D. Pa. 2004).

${ }^{23}$ Meijer Inc. v. 3M, C.A. No. 04-5871, Answer, 8/2/2005 (E.D. Pa. 2004).

${ }^{24}$ The class was defined as follows: "all persons and entities who purchased invisible or transparent tape directly from 3M Company, or any subsidiary or affiliate thereof, in the United States at any time during the period from October 2, 1998 to the present (the 'Class Period'). The Class excludes defendant, its subsidiaries, affiliates, officers, and directors. The Class further excludes all person and entities who have not purchased invisible or transparent tape for resale under their own label at any time from October 2, 1988 to the present.” Meijer Inc. v. 3M, C.A. 04-5871, Plaintiff's Motion for Class Certification, 9/6/2005 (E.D. Pa. 2004).

${ }^{25}$ Meijer Inc. v. 3M, C.A. No. 04-5871, Declaration of Daniel A. Small in Support of Plaintiffs' Motion for Final Approval of Proposed Settlement, 5/23/2006; Meijer Inc. v. 3M, C.A. No. 04-5871, Motion for Preliminary Approval of Settlement, 2/13/2006.
}

(CDavis \& Lande: This paper is a draft and subject to amendment. 
approval of Meijer's proposed settlement and proposed settlement class. ${ }^{26}$ On March 9, 2006, the court denied Bradburn's motion to intervene. ${ }^{27}$ On March 28, 2006, the court granted preliminary approval of the settlement. The preliminary approval defined the settlement class as "all person and entities that purchase invisible or transparent tape directly from 3M, or any subsidiary or affiliate thereof, in the United States at any time during the period from October 2, 1998 to February 10, 2006 and also purchased for resale under the class member's own label, any 'private label' invisible or transparent tape from 3M or any of 3M Company, its subsidiaries, affiliates, officers, directors, and employees and excluding those persons or entities that timely and validly request exclusion from the Settlement Class. ${ }^{28}$

Because the parties had settled, on May 10, 2006, the trial court dismissed plaintiff's motion for class certification without prejudice. ${ }^{29}$ On August 1, 2006, the Settlement Fund totaled $\$ 27,783,836.97 .^{30}$ Plaintiffs' Counsel requested an award of $\$ 7.5$ million in attorneys' fees and a reimbursement of $\$ 390,452.46$ in expenses. Meijer requested an incentive award of $\$ 25,000 .{ }^{31}$ The Court used the percentage of recovery method to assess the award of attorneys' fees and then applied the Lodestar method to cross check the percentage fee award and verify it was not excessive. In this case, the requested attorneys' fees would result in a percentage recovery of $27.4 \%$. The Court then determined that the percentage of recovery fee award was reasonable using the seven factors set forth in Gunter v. Ridgewood Energy Corp., 223 F.3d 190 (3d Cir. 2000). ${ }^{32}$

\footnotetext{
${ }^{26}$ The proposed class was as follows: “all persons and entities that purchased invisibile or transparent tape directly from 3M, or any subsidiary or affiliate thereof, in the United States at any time during the period from October 2, 1998 to February 10, 2006 and also purchased for resale under the class member's own lable, any 'private label' invisible or transparent tape from 3M or any of 3M's competitors at any time from October 2, 1998 to February 10, 2006; but excluding 3M Company, its subsidiaries, affiliates, officers, directors, and employees and excluding those persons or entities that timely and validly request exclusion from the Settlement Class.” Meijer Inc. v. 3M, C.A. No. 04-5871, Memorandum of Law in Support of Motion for Preliminary Approval of Settlement, 2/13/2006 (E.D. Pa. 2003).

${ }^{27}$ Meijer Inc. v. 3M, C.A. No. 04-5871, Order Granting Final Approval and Dismissal With Prejudice, 8/15/2006.

${ }^{28}$ Meijer Inc. v. 3M, C.A. No. 04-5871, Order Granting Preliminary Approval of Settlement, 3/28/2006.

${ }^{29}$ Meijer Inc. v. 3M, C.A. No. 04-5871, Order Denying Motion for Class Certification, 5/10/2006.

${ }^{30}$ Meijer Inc. v. 3M, C.A. No. 04-5871, Memorandum in Further Support of Plaintiffs' Motion for Final Approval of Settlement, at n. 6, 8/1/2006.

${ }^{31}$ Meijer Inc. v. 3M, C.A. No. 04-5871, Memorandum in Further Support of Plaintiffs' Counsel's Motion for Attorneys' Fees, Expenses, and Incentive Award, 8/1/2006.

${ }^{32}$ Meijer Inc. v. 3M, C.A. No. 04-5871, Order Granting Final Approval of Settlement and Dismissal With Prejudice, 8/15/2006.
}

(CDavis \& Lande: This paper is a draft and subject to amendment. 


\section{Air Cargo Shipping Services Antitrust Litigation ${ }^{1}$}

This case is notable because: (1) the direct purchaser plaintiffs ${ }^{2}$ received a total in damages of \$278 million; (2) the plaintiffs' attorneys were awarded 15\% of the settlement fund for their fees; (3) the case exemplifies the need for private antitrust enforcement along with public enforcement because while simultaneous government action imposed significant criminal fines, it did not compensate hundreds of thousands of purchasers.

\section{A. Procedural Background}

The plaintiffs in the class action (and the Lufthansa settlement) are all direct and indirect purchasers of airline freight and passenger services, and are located in the US and abroad (principally in the E.U.). Apart from Lufthansa Airlines, the defendants are Air Canada, Air France, KLM, ABSA (Aerolineas Brasileiras S.A.), LAN, Alitalia, All Nippon Airways (ALA), Asiana Airlines, British Airways, Cargolux, Cathay Pacific, Air China, DAS Air Cargo, Lufthansa, Swiss, El Al, Emirates, JAL, Korean Air, Martinair, Air New Zealand, Nippon Cargo, Atlas Air, Polar Air, Qantas, Saudi Arabian Airlines, SAS, Singapore Airlines, South African Airways, Thai and VARIG. The class action is continuing as of 09/2010.

On or before 31 December 2005, Lufthansa approached the US Department of Justice and made an application under the DoJ's Corporate Leniency Program. ${ }^{3}$ Lufthansa revealed the existence of a global conspiracy among the defendants beginning in or around 1 January 2000, to inflate prices in airline freight and passenger services. Through regular and intricate coordination, the defendants jointly raised and maintained prices, eliminated discounting, allocated markets (of customers, routes and territories), restricted supply, and levied new, artificially inflated surcharges, particularly fuel surcharges. In representations in the public media, to customers and analysts, surcharges and price increases were routinely justified as legitimate, on the pretext that they were based on rising costs. ${ }^{4}$ The cartel was discovered only by Lufthansa's leniency application.

A coordinated global antitrust investigation into the airline industry by United States, European, Korean, and Canadian competition promptly followed. Publicity on that investigation led to over 100 private filings in district courts throughout the United States. On June 20, 2006, the Judicial Panel on Multidistrict Litigation ordered that pursuant to 28 U.S.C. $§ 1407$, all air cargo lawsuits be transferred and consolidated for pretrial proceedings to the United States District Court for the Eastern District of New York. ${ }^{5}$ The case was assigned to Judge John Gleeson, an appointee of President William Clinton. ${ }^{6}$

The plaintiffs before Judge Gleeson numbered over $300,000^{7}$ and were geographically dispersed. $^{8} \quad$ Direct purchasers included freight forwarders, importers and sellers of

${ }^{1}$ 06-MD-1775

${ }^{2}$ All private recoveries in this case were by direct purchasers. See email from Mandrika Moonsammy to Joshua

Davis of July 26, 2012 (on file with author).

${ }^{3}$ Amended Complaint, paragraphs 139-140; Settlement Agreement (09-11-06), paragraph 77.

${ }^{4}$ Id., paragraphs $124-133$

${ }^{5}$ Judge John Gleeson, Order. Approval of Settlement, 25 Sep 09

${ }^{6}$ http://en.wikipedia.org/wiki/John_Gleeson_\%28judge\%29

${ }^{7}$ Exhibit A to Final Judgment Approving Lufthansa Settlement, 10/06/2009

${ }^{8}$ Amended Complaint, paragraphs 160, 194, 240

(CDavis \& Lande: This paper is a draft and subject to amendment. 
comprehensive shipping services who contracted a portion of their services to the defendants. ${ }^{9}$ Indirect purchasers included businesses across a wide variety of trade, from well-known brands to small enterprises around the world.

The plaintiffs were organized into classes of direct and indirect purchasers located in the U.S., and of direct and indirect purchasers located outside the U.S who either purchased airfreight shipping services for trade solely between the US and a European nation, or for trade solely between European nations. All classes of plaintiffs claimed treble damages and injunctive relief for violations of Section 1 of the Sherman Act. ${ }^{10}$ Indirect US purchasers in certain states claimed damages and injunctions under state antitrust, unfair competition and consumer protection laws and common law. ${ }^{11}$ Foreign-based purchasers involved in trade between the US and the rest of world including the EU additionally claimed under European antitrust acts. ${ }^{12}$

The injuries the plaintiffs claimed were the payment of supra-competitive or artificially high prices ${ }^{13}$ and being deprived of a competitive market. ${ }^{14}$ In arguing for the inclusion of foreign purchasers' claims, they maintained that the damage to commerce outside the US was "interdependent and inextricably bound" with the damage to US commerce, ${ }^{15}$ and noted that $40 \%$ of the world's annual air cargo services involves trade to and from the US: "Defendants could not have maintained their international price-fixing arrangement for Airfreight Shipping Services that caused foreign injury to the E.U. Indirect Foreign Plaintiffs and the members of E.U. Indirect Foreign Subclass without impacting adversely the prices of Airfreight Shipping Services to, from, and within the U.S."16

Neither the state law claims (due largely to arguments based on pre-emption by the Airline Deregulation Act of 1978) nor the EU law claims (on forum non conveniens and international comity arguments) survived motions to dismiss. ${ }^{17}$ The Sherman Act claims, however, did survive, despite application of the Supreme Court's decision under Twombly. The fact that 15 defendants had already pled guilty to the same conduct in USDoJ prosecutions supported the Sherman Act claims. ${ }^{18}$

\section{B. Settlement}

On September 11, 2006, Lufthansa executed a settlement agreement with very favorable terms toward the Plaintiffs. It covered all US and foreign direct and indirect purchasers of shipping services "within, to or from the United States."19 It created a settlement fund of $\$ 85$ million, plus interest until the date of eventual judicial approval in 2008 ( $\sim 5$ million). Lufthansa

\footnotetext{
${ }^{9}$ As named in the Complaint.

${ }^{10}$ Amended Complaint, throughout, and paragraphs 232, 241(b), 267, 278

${ }^{11}$ Id., paragraphs 161(b), 195(b)-(e); state antitrust statutes enumerated at paragraph 213; state unfair competition and consumer protection statutes enumerated in paragraph 218.

${ }^{12}$ Id., paragraphs 278(c)-(d), 307, 328(b)-(c), 353. The claims in EU law were specifically Article 81 EU Treaty and Article 53 of the EEA Agreement.

${ }^{13}$ Id., paragraph 248

${ }_{15}^{14}$ Id., paragraphs 208-210, 248

${ }^{15}$ Id., paragraph 286.

${ }^{16}$ Id., paragraph 321

${ }^{17}$ Report and Recommendation Pursuant to 28 U.S.C § 636(b)(1), Magistrate Judge Victor Pohorelsky, 26 September 2008

${ }^{18}$ Order, Judge John Gleeson, 21 August 2009

${ }^{19}$ Settlement Agreement, paragraph A-1; Plaintiff's Memorandum in Support of an Unopposed Motion etc. 24 Oct 2007, second paragraph.
}

(CDavis \& Lande: This paper is a draft and subject to amendment. 
bore the expense of administering, investing and distributing the settlement fund (in accordance with the settlement agreement), including notifying and communicating with the 300,000 members of the settlement class. ${ }^{20}$ Lufthansa agreed to lend "extensive" cooperation to aid in the prosecution of the non-settling defendants. ${ }^{21}$

The settlement class excluded all government entities.

The $\$ 85$ million was calculated to be $10.5 \%$ of the value of Lufthansa's various surcharges from January 1, 2000 to September $11,2006 .^{22}$

The settlement fully released Lufthansa and subsidiaries (Swiss, Deutsche Lufthansa and Lufthansa Cargo) from all private liability in state and federal law, for all conduct arising out of their participation in the cartel. The plaintiffs had no fiscal remedy apart from the \$85 million settlement fund, ${ }^{23}$ and their attorneys' fees were to come out of that fund. ${ }^{24}$

Judge Gleeson found the settlement to be fair: of the 300,000 class members notified, there had not been a single objection, and only 37 members had opted out. ${ }^{25}$ Counsel had won "hard-fought" benefits for the plaintiffs, and the litigation was "irrefutably complex." The \$85 million settlement sum was "a result that compares favorably to settlements reached in other price-fixing antitrust class actions" and was reasonable in light of "the best possible recovery". ${ }^{26}$

In noting the "highly experienced" attorneys' "vigorous" negotiation on behalf of the plaintiffs, Judge Gleeson stated, "Settlement Counsel has been consistently commended in this case, deservedly so." ${ }^{27}$ He awarded counsel $15 \%$ of the settlement amount (\$12.5 million), plus expenses of \$1,572,101. This was in excess of the lodestar of their work through Dec 312008 in respect of the Lufthansa Settlement, which counsel submitted was \$9,858,594 (\$8,286,093 plus expenses of $\$ 1,572,101){ }^{28}$

The motion for settlement approval was filed in court on October 24, 2007; its approval was finalized on October 6, 2009. During this time (throughout 2007 to 2009), the USDoJ prosecuted and obtained guilty pleas and criminal fines via plea agreements, as follows:

\begin{tabular}{|l|l|}
\hline Defendant & Fine \\
\hline British Airways & $\$ 300$ million $^{29}$ \\
\hline Korean Airways & $\$ 300$ million $^{30}$ \\
\hline Air France \& KLM & $\$ 350$ million \\
\hline JAL & $\$ 110$ million \\
\hline LAN, ABSA & $\$ 109$ million $^{31}$ \\
\hline
\end{tabular}

${ }^{20} I d$., paragraph 47

${ }^{21}$ Plaintiffs' Memorandum In Support of Its Motion for Final Approval of Settlement with Lufthansa, 11/12/08, at 1 and 8

${ }^{22}$ Memorandum in Support of Plaintiffs' Motion for Final Approval of Settlement with Lufthansa, 12 Nov 08, at 25.

${ }^{23}$ Settlement Agreement, paragraph 41

${ }^{24} \mathrm{Id}$, paragraph 47

${ }^{25}$ Exhibit A to Final Judgment Approving Lufthansa Settlement, 10/06/2009

${ }^{26}$ Discussion Section of Judge Gleeson's Order Approving Settlement of 25 Sep 09, (A)(1)(b).

${ }^{27}$ Judge Gleeson, Memorandum and Order Approving Lufthansa Settlement, 25 Sep 09, at 28

${ }^{28} \mathrm{Ibid}$, at 30

${ }^{29}$ United States of America v British Airways PLC, Plea Agreement, 08-23-2007

${ }^{30}$ USDoJ Press Release. British Airways Plc and Korean Air Lines Co., Ltd. Agree to Plead Guilty and Pay Criminal Fines Totaling \$600 Million for Fixing Prices on Passenger and Cargo Flights. 08-1-2007. http://www.justice.gov/atr/public/press_releases/2007/224928.htm. Accessed 11 Sep 10.

${ }^{31}$ United States of America v LAN \& ABSA, Plea Agreement, 19 Feb 2009.

http://www.justice.gov/atr/cases/f243000/243067.htm

(CDavis \& Lande: This paper is a draft and subject to amendment. 


\begin{tabular}{|l|l|}
\hline Nippon & \$45 million $^{32}$ \\
\hline Qantas & $\$ 61$ million $^{33}$ \\
\hline Asiana & $\$ 50$ million $^{34}$ \\
\hline El Al & $\$ 15.7$ million \\
\hline Martinair & $\$ 42$ million \\
\hline Cathay Pacific & $\$ 60$ million \\
\hline Cargolux & $\$ 119$ million \\
\hline SAS & $\$ 52$ million \\
\hline Total fines & $\mathbf{\$ 1 , 6 1 3 . 7}$ million \\
\hline
\end{tabular}

There have been additional settlements with the totals to date as follows: ${ }^{35}$

\begin{tabular}{|l|l|l|}
\hline Settling Airline & $\begin{array}{l}\text { Motion } \\
\text { granted }\end{array}$ & Settlement Amount \\
\hline Lufthansa & $3 / 14 / 2011$ & $\$ 85$ million \\
\hline $\begin{array}{l}\text { Air France, KLM, } \\
\text { Martinair }\end{array}$ & $3 / 14 / 2011$ & \$87 million + \$500K for notice to class \\
\hline JAL & $3 / 14 / 2011$ & $\$ 12$ million \\
\hline $\begin{array}{l}\text { AMR Corp, American } \\
\text { Airlines }\end{array}$ & $3 / 14 / 2011$ & $\$ 5$ million \\
\hline SAS & $3 / 14 / 2011$ & $\begin{array}{l}\text { \$13.93 million + \$500K notice \& } \\
\text { notice administration }\end{array}$ \\
\hline Cargolux & $7 / 22 / 11$ & $\$ 35.1$ million \\
\hline ANA & $7 / 22 / 11$ & $\$ 10.4$ million \\
\hline Thai Airways & $7 / 22 / 11$ & $\$ 3.5$ million \\
\hline Quantas & $8 / 4 / 11$ & $\$ 26.5$ million \\
\hline
\end{tabular}

As of September 2010, there have been no USDoJ prosecutions of Alitalia, Emirates, Saudi Arabian, Singapore, South African, VARIG, Ethiopian, Air New Zealand, or Thai.

There have not been any prosecutions of this cartel by state governments. ${ }^{36}$

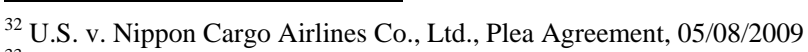

${ }^{33}$ U.S. v. Qantas Airways Ltd, Plea Agreement, 01/14/2008

${ }^{34} 05 / 05 / 2009$

${ }^{35}$ See http://www.aircargosettlement2.com/ (last visited 9/7/2011).

${ }^{36}$ According to a Westlaw search of state case law, conducted in September 2010.

CDavis \& Lande: This paper is a draft and subject to amendment.
} 


\section{De Beers (Sullivan v. DB Investments, Inc. $)^{1}$}

This case is notable because: (1) the plaintiffs settled for a total of \$295 million; (2) the Indirect Purchasers received \$272.5 million and the Direct Purchasers received \$22.5 million; (3) the attorneys were awarded $25 \%$ in fees and under $1 \%$ in expenses; (4) the court awarded $\$ 220,000$ in incentive awards to the class representatives; (5) the settlement included a stipulated injunction that required De Beers, among other things, to comply with antitrust laws and to submit itself to the personal jurisdiction of the United States to enforce the settlement; (6) the defendants are a completely foreign corporation returning money to American businesses and consumers; and (7) the case clarified the law regarding class certification generally, and in the settlement and antitrust context.

\section{Factual Background}

During most of the $20^{\text {th }}$ Century, De Beers has been the leading participant in the wholesale market for gem-quality diamonds. ${ }^{2}$ According to the plaintiff's complaints, De Beers engaged in conduct to coordinate the worldwide sale of diamonds. Such conduct included, “executing out-put purchase agreements with competitors, synchronizing and setting production limits, restricting the resale of diamonds within certain geographic regions, and directing marketing and advertising.”3 Essentially, De Beers' conduct allowed them to control the quantity and prices of diamonds in the global marketplace by restricting sales to their preferred wholesalers referred to as "sightholders."4 The sightholders constituted De Beers' main channel and distribution by reselling these diamonds to manufacturers and retailers. ${ }^{5}$

\section{Procedural Background}

\section{A. Preliminary Proceedings}

In 2001 and 2002 plaintiffs brought lawsuits against defendant, claiming that the companies practices violated state and federal antitrust, consumer protection, and unjust enrichment laws. ${ }^{6}$ Additionally, the complaints stated that the conduct constituted unfair business practices and false advertising under both common law and state law. ${ }^{7}$ Ultimately, the plaintiffs claimed that De Beers used its dominant position to artificially inflate prices, causing purchasers of diamonds to overpay for diamond products. ${ }^{8}$ The plaintiffs claimed Section 1 and 2 violations of the Sherman Act, which amount to a per se violation. ${ }^{9}$ The present case started as seven individual lawsuits that were transferred and consolidated to the U.S. District Court for the

\footnotetext{
${ }^{1}$ No. 08-2784 et al. (3 ${ }^{\text {rd }}$ Cir. Dec. 21, 2011) (en banc).

${ }^{2}$ Sullivan v. DB Investments, Inc., No. 08-2784 et al., 12 (3 $3^{\text {rd }}$ Cir. Dec. 21, 2011)(en banc).

${ }^{3} I d$.

${ }^{4}$ Id. at $12-13$.

${ }^{5} \mathrm{Id}$. at 13 .

${ }^{6}$ Defendants include DB Investments, Inc.; De Beers S.A.; De Beers Consolidated Mines, Ltd.; De Beers A.G.;

Diamond Trading Company; CSO Valuations A.G.; Central Selling Organization; and De Beers Centenary A.G.

${ }^{7}$ Id. at $13-14$.

${ }^{8}$ Id. at 14.

${ }^{9} I d$. at $14-15$, n. 6 .
} 
District of New Jersey. ${ }^{10}$ Four of these lawsuits began in federal district courts, one was removed from state court to federal court, and two were state court cases in California and Arizona. ${ }^{11}$

De Beers initially denied that the U.S. Courts had personal jurisdiction in these cases, arguing that they never transacted business directly with the United States. De Beers had been taking this position for over half of a century. As a result, all of the lawsuits except Cornwell initially ended in default or default judgment. ${ }^{12}$

\section{B. Settlement}

De Beers eventually approached plaintiff's counsel in May 2005 and negotiated a \$250 million settlement with Indirect Purchasers. ${ }^{13}$ De Beers additionally agreed to not contest certification of the settlement class of indirect purchasers and stipulated an injunction that enjoined De Beers from engaging in conduct that violated United States Antitrust laws. ${ }^{14}$ Finally, De Beers consented to limited jurisdiction in order to fulfill the terms of the settlement and for enforcement of the injunction. On November 30, 2005 the District court entered an order that approved the settlement and conditionally certified the indirect purchaser class pursuant to Federal Rule of Civil Procedure 23(b)(2) and 23(b)(3). ${ }^{15}$

De Beers then negotiated a settlement with the direct purchasers in Anco and British Diamond in March 2006. The terms of the direct purchasers settlement were the same as the agreement with the indirect purchasers and established a \$22.5 million fund. The settlement also increased the indirect purchaser fund by $\$ 22.5$ million to accommodate putative class members in Anco and British Diamond who were indirect purchasers that did not participate in the previous settlement. ${ }^{16}$ This led to a total settlement of \$295 million between the direct and indirect purchasers.

The District Court then modified its original order on March 31, 2006 to include the direct purchasers settlement class and to preliminarily approve the settlement for both classes. The settlement provided for a stipulated injunction that required "De Beers to, inter alia, comply with and abide by federal and state antitrust laws, to limit its purchases of diamonds from thirdparty producers, to abstain from setting or fixing the prices of diamonds sold by third-party producers, to desist from restricting the geographic regions within which sightholders could resell De Beers diamonds, and barred De Beers from purchasing diamonds in the United States for the principal purpose of restraining supply., ${ }^{17}$ De Beers agreed to subject itself to PJ to enforce the combined settlement agreement.

\section{Referral to Special Master}

\footnotetext{
${ }^{10}$ The seven original lawsuits were: Sullivan v. DB Investments, Inc., Index No. 04-cv-02819 (D.N.J.); Null v. DB Investments, Inc., Madison Co. No 05-L-209 (Madison County, Ill. Cir. Ct., removed to S.D. Ill.); Leider v. Ralfe, No. 01-CV-3137 (S.D.N.Y.); Anco Industrial Diamond Corp. v. DB Investments, Inc., No. 01-cv-04463 (D.N.J.); British Diamond Import Co. v. Central Holdings Ltd., No. 04-cv-04098 (D.N.J.); Hopkins v. De Beers Centenary A.G., San Francisco County No. CGC-04-432954 (Cal. Super. Ct.); and Cornwell v. DB Investments, Inc., Maricopa Co. No. CV2005-2968 (Ariz. Super. Ct.). Id. at 10, n. 1.

${ }^{11}$ Id. at 14-15.

${ }^{12} \mathrm{Id}$. at 16.

${ }^{13}$ Id. This settlement included the Sullivan, Hopkins, Null and Cornwell cases.

${ }^{14} \mathrm{Id}$. at $16-17$.

${ }^{15} \mathrm{Id}$. at 17 .

${ }_{17}^{16} \mathrm{Id}$.

${ }^{17} \mathrm{Id}$. at 18
} 
Following preliminary approval by the District Court, the case was referred to a Special Master for advisement. ${ }^{18}$ The Special Master found the settlement fair, reasonable and adequate based on the nationwide Indirect and Direct Purchaser classes. ${ }^{19}$ The Indirect Purchaser class was divided into two subclasses for consumers and resellers. ${ }^{20}$ According to the Special Master the Indirect Purchaser settlement fund should be allocated with 50.3\% (approximately $\$ 137.1$ million) going to the Resellers and $49.7 \%$ (approximately $\$ 135.4$ million) going to the Consumer Subclass. ${ }^{21}$ Claims that resulted in a de minimis recovery of less than $\$ 10$ should not be paid due to high administrative costs. Additionally, it was found that the requested $25 \%$ in attorneys fees and less than $1 \%$ for expenses was reasonable under the percentage of recovery approach, as cross-checked by the lodestar method. Finally, the Special Master decided that $\$ 220,000$ requested in incentive awards for class representatives was appropriate in light of the benefits for the class and litigation risks. ${ }^{22}$

On March 22, 2008 the District Court rejected all of the objections and entered a final order that certified the Direct and Indirect Purchasers classes under Federal Rule of Civil Procedure 23(b)(2) and 23(b)(3). The order also included the stipulated injunction, which was to remain effective for five years. The objectors then appealed. ${ }^{23}$

\section{Appeal to Third Circuit}

The Third Circuit originally "held that the District Court's ruling was inconsistent with the predominance inquiry mandated by FRCP 23(b)(3), and remanded for further proceedings."24 The court granted the plaintiffs' petition to rehear the case en banc and ultimately vacated their original order. The court held en banc that the District Court properly certified the two classes and did not run afoul of Federal Rule of Civil Procedure 23(c)(1)(B). ${ }^{25}$ Furthermore, the District Court's acceptance of De Beer's stipulated injunction was within their discretion. ${ }^{26}$ The Third Circuit upheld the District Court's approval of the settlement, allocation plan, and award of attorney's fees. ${ }^{27}$ It has yet to be seen if the objector's will attempt to appeal to the United States Supreme Court.

\footnotetext{
${ }^{18} \mathrm{Id}$.

${ }^{19}$ The parties agreed to seek certification of the settlement classes under these definitions. The Direct Purchaser class was defined as "All natural persons and legal entities located in the United States who purchased any Gem Diamond directly from a Defendant or Defendants' Competitors (including any entity controlled by or affiliated with any such party) from September 20, 1997 to the date of settlement class certification.” They agreed to define the Indirect Purchaser class as "All natural persons and legal entities located in the United States who purchased any Diamond Product from January 1, 1994 to the date of settlement class certification, provided that any purchases of any Gem Diamond made directly from a Defendant (including any entity in which any Defendant has a controlling interest and any affiliate of any Defendant) or Defendants' competitors (including any entity controlled by or affiliated with any such party) shall be excluded. Id. at 19-20.

${ }^{20}$ Id. at 20 .

${ }^{21} \mathrm{Id}$. at 21 .

${ }^{22}$ Id. at 23 .

${ }^{23} \mathrm{Id}$. at 28.

${ }^{24} \mathrm{Id}$. at 11 .

${ }^{25} \mathrm{Id}$. at 78 .

${ }^{26} \mathrm{Id}$. at 85.

${ }^{27}$ Id. at $100,107,115$.
} 


\section{Related Actions}

\section{A. Department of Justice}

De Beers was previously charged by the Justice Department in 1994 for conspiring to fix the prices for industrial diamonds in the United States and elsewhere. Originally De Beers was charged alongside General Electric as a co-conspirator, but GE was acquitted. After 10 years of these charges preventing any De Beers executives from even travelling to the United States, De Beers pleaded guilty and agreed to pay $\$ 10$ million to settle the charges in July $2004 .{ }^{28}$ U.S. District Judge George Smith accepted the plea and did not order restitution because a separate settlement of a civil case resolved that issue. ${ }^{29}$

\section{B. European Commission}

In February 2006, De Beers entered into an agreement with the European Commission to cease their purchase of uncut diamonds from their main competitor by the end of $2008 .^{30}$

\section{Presiding Judges}

George W. Bush appointed United States District Judge Stanley R. Chesler. The en banc panel of judges in the Third Circuit consisted of nine judges. Clinton appointed the judge who wrote the Third Circuit's en banc opinion. Of the judges joining in the majority, three were appointed by Democratic presidents and three by Republican presidents. Both of the dissenting judges in the en banc opinion were appointed by Republican presidents.

\footnotetext{
${ }^{28}$ Margaret Webb Pressler, DeBeers Pleads Guilty to Price-Fixing, The Washington Post, July 14, 2004, http://www.washingtonpost.com/wp-dyn/articles/A48041-2004Jul13.html.

${ }^{29}$ De Beers Pleads Guilty in Price Fixing Case, World Business on MSNBC, July 13, 2004, http://www.msnbc.msn.com/id/5431319/\#.TwpzdGA4dUt.

${ }^{30}$ De Beers Loosens Grip on Diamond Market, New York Times, February 22, 2006,

http://www.nytimes.com/2006/02/22/business/worldbusiness/22iht-diamond.html
} 


\section{Electrical Carbon Products Antitrust Litigation ${ }^{1}$}

This case is notable because: (1) the plaintiffs received a total of $\$ 29.975$ million; (2) the plaintiffs' attorneys were awarded $25 \%$ for fees, not including costs and expenses, in the Morgan, Schunk and SGL settlement, and $331 / 3 \%$ in the Carbone settlement; ${ }^{2}$ (3) the court awarded \$493,078.17 for costs and expenses; (4) the case involved related government and nongovernment investigations and fines; (5) the case received an appeal.

\section{A. Factual Background}

Electric carbon products include carbon brushes and current collectors used in the manufacture of direct current electric motors, automotive applications and other transit applications as well as consumer products, and also mechanical carbon products used in pump and compressor industries. Carbon brushes are used to transfer electrical current in direct current motors by acting as the rubbing contacts for electrical connectors. Direct current motors are used in a variety of products including automobiles, battery operated vehicles and public-transit vehicles. Carbon collectors are used to transfer electrical current from wires or rails for use in transit vehicles that are not independently powered. Mechanical carbon products are sold primarily to pump seal manufacturers and are used in fluid handling markets for containing liquids in wear situations. ${ }^{3}$

\section{B. Related Actions}

\section{i. Department of Justice Investigation}

In November 2002, the Department of Justice (DOJ) and Morganite, Inc. entered into a plea agreement. The DOJ alleged that Morganite conspired to suppress and eliminate competition by fixing the prices of certain electrical carbon products in the United States, a Section 1 violation of the Sherman Act. Morganite waived indictment and pleaded guilty, admitting all counts of the information. The district court sentenced Morganite to pay a \$10 million fine for its participation in the conspiracy. ${ }^{4}$

The November 2002 petition also alleged that Morgan Crucible attempted to influence the testimony of witnesses in official proceedings related to the investigation of the conspiracy. Morgan Crucible was sentenced to pay a $\$ 1$ million fine. ${ }^{5}$

On September 24, 2003, a grand jury filed indictments against four individuals: former MECL employee, Robin D. Emerson; MAMAT director, F. Scott Brown; Morgan Crucible director, Jacobus Johan Anton Kroef; Morgan Crucible CEO, Ian Norris. The indictments contained allegations of witness tampering, obstruction of justice, document destruction, and participation in a conspiracy. ${ }^{6}$

\footnotetext{
${ }^{1}$ C.A. No. 1:03-cv-02182 (N.J. 2003)

${ }^{2}$ In re Elec. Carbon Products Antitrust Litigation, 622 F.Supp.2d 144, D.N.J.,2007

${ }^{3}$ In Re Electrical Carbon Products Antitrust Litigation, C.A. No. 1:03-cv-02182, Consolidated Third Amended Class Action Complaint, 2/12/2004 (N.J. 2003).

${ }^{4} I d$.

${ }^{5} \mathrm{Id}$.

${ }^{6} \mathrm{Id}$.
} 


\section{ii. The European Commission}

On December 3, 2003, the European Commission issued fines totaling $€ 101.44$ million against the companies participating in the conspiracy. The fines were divided as follows: Le Carbone Lorraine (43.05 million euros); Schunk GmbH and Schunk Kohlenstoff-Technik GmbH (30.87 million euros); SGL Carbon A.G. (23.64 million euros); Hoffman \& Co. (2.82 million euros); and Conradty (1.06 million euros). Morgan Crucible was granted immunity because it was the first company to provide information about the cartel agreements. ${ }^{7}$

\section{Current Litigation}

\section{i. $\quad$ Preliminary Proceedings}

Direct purchasers filed various private actions. On May 15, 2003, six cases from the Eastern District of Pennsylvania, ${ }^{8}$ along with three cases from the District of New Jersey, ${ }^{9}$ were consolidated into the above titled litigation in the District of New Jersey by a multi-district litigation panel. ${ }^{10}$ The case was assigned to the Honorable Jerome B. Simandle. ${ }^{11}$ On June 2, 2003, another multi-district litigation panel transferred an additional six cases ${ }^{12}$ into the consolidated litigation. ${ }^{13}$

Plaintiffs consist of various direct purchasers of electrical carbon products in the United States during January 1, 1990, through December 31, 1999 (Class Period). On August 27, 2003, the Consolidated Amended Class Action Complaint alleged that defendants ${ }^{14}$ and their alleged co-conspirators engaged in a continuing combination and conspiracy with respect to the sale of

${ }^{7} I d$.

${ }^{8}$ South-Land Carbon Products, Inc. v. Morganite, Inc., et al, C.A. No. 1:02-5503; Trupar America, Inc. v. Morganite, Inc., et al., C.A. No. 1:02-5668; Koffler Electrical Mechanical Apparatus Repair, Inc. v. Morganite, Inc., C.A. No. 1:02-5678.

${ }_{9}^{9}$ Lockwood Electric Motor Service of Trenton, NJ v. Morganite, Inc., C.A. No. 2:02-8379; U.S. Material Supply, Inc. v. Morganite, Inc., C.A. No. 2:02-8456; Regional Transit Authority, et al., v. Morganite, Inc., et al., C.A. No. 2:02-8506; Pincus Elevator \& Electric Co., Inc. v. Morganite, Inc., C.A. No. 2:02-8567; The Port Authority Transit Corp. v. Morganite, Inc., C.A. No. 2:02-8738; Bright Lights USA, Inc. v. Morganite, Inc., C.A. No. 2:02-8866.

${ }^{10}$ In Re Electrical Carbon Products Antitrust Litigation, C.A. No. 1:03-cv-02182, Transfer Order, 5/13/2003 (N.J. 2003).

${ }^{11}$ Simandle was appointed by Republican President George H.W. Bush. http://en.wikipedia.org/wiki/Jerome_B._Simandle

12 The cases were as follows: City \& County of San Francisco v. Morganite, Inc., et al, C.A. No. 3:03-0209 (N.D. Ca. 2003); Chicago Transit Authority v. Morganite, Inc., et al., C.A. No. 1:02-9156 (N.D. Il. 2002); R. Scheinert \& Son, Inc. v. Morganite, Inc., C.A. No. 2:02-9027 (E.D. Pa. 2002); National Railroad Passenger Corp. v. Morganite, Inc., C.A. No. 2:02-9156 (E.D. Pa. 20020); Southeastern Pennsylvania Transportation Authority v. Morganite, Inc., C.A. No. 2:03-0947 (E.D. 2003); Ram Industries, Inc., etc. v. Morganite, Inc., et al., C.A. No. 2:03-1440 (E.D. 2003).

${ }^{13}$ In Re Electrical Carbon Products Antitrust Litigation, C.A. No. 1:03-cv-02182, Transfer Order, 6/2/2003 (N.J. 2003).

${ }^{14}$ The originally named defendants were as follows: Morganite, Inc.; Morgan Crucible Company PLC; Morganite Industries; Carbone Lorraine North America Corporation; Carbone of America Industries Corp.; Le Carbone Lorraine. In Re Electrical Carbon Products Antitrust Litigation, C.A. No. 1:03-cv-02182, Consolidated Amended Class Action Complaint, 8/27/2003 (N.J. 2003). 
electrical carbon products in unreasonable restraint of trade and commerce, in violation of Section 1 of the Sherman Act, 15 U.S.C. $\$ 1 .^{15}$

On November 7, 2003, a Consolidated Second Amended Class Action Complaint was filed. ${ }^{16}$ On December 11, 2003, defendants moved to dismiss the Consolidated Second Amended Class Action Complaint for lack of personal jurisdiction and failure to state a claim. ${ }^{17}$ On February 12, 2004, Plaintiffs ${ }^{18}$ filed a Consolidated Third Amended Class Action Complaint. This complaint added parties as defendants, and placed them into the following groups: The Morgan Defendants; ${ }^{19}$ the Carbone Defendants; ${ }^{20}$ the Schunk Defendants; ${ }^{21}$ the SGL Defendant; $^{22}$ and Conradty. ${ }^{23}$ It alleged that Defendants conspired to fix, raise, stabilize and maintain at artificially high levels the price of electrical carbon products. ${ }^{24}$

On March 12, 2004, a group of defendants ${ }^{25}$ moved to dismiss the Third Amended Complaint for failure to state a claim and based on violation of the statute of limitations. ${ }^{26}$ Also on March 12, 2004, defendant Le Carbone Lorraine S.A. filed a motion to dismiss the Third Amended Complaint for lack of personal jurisdiction. Le Carbone Lorraine S.A. is a French corporation with its principal place of business in La Defense, France. ${ }^{27}$ On March 29, 2004, Hoffman Carbon, Inc. moved to dismissed for failure to state a claim and based on violation of

\footnotetext{
${ }^{15}$ In Re Electrical Carbon Products Antitrust Litigation, C.A. No. 1:03-cv-02182, Consolidated Amended Class Action Complaint, 8/27/2003 (N.J. 2003).

${ }^{16}$ Re Electrical Carbon Products Antitrust Litigation, C.A. No. 1:03-cv-02182, Consolidated Second Amended Class Action Complaint, 11/7/2003 (N.J. 2003).

${ }^{17}$ Re Electrical Carbon Products Antitrust Litigation, C.A. No. 1:03-cv-02182, Notice of Motion and Motion of Defendant Morgan Crucible Company PLC to Dismiss the Second Amended Complaint (FRCP 12(B)(2) and 12(B)(6), 1/12/2004 (N.J. 2003).

${ }^{18}$ Plaintiffs is defined as the follow group: San Francisco Bay Area Rapid Transit (BART); City and County of San Francisco (CCSF); Metro-North Commuter Railroad Company (Metro-North); Long Island Rail Road Company (LIRR); New York Transit Authority (NYCTA); Southeastern Pennsylvania Transportation Authority (SEPTA); Lockwood Electric Motor Service (Lockwood).

${ }^{19}$ The Morgan Crucible Company PLC; Morganite, Inc.; Morganite Industries, Inc.; Morgan Advanced Materials and Technology, Inc.; Morganite Electrical Carbon Ltd.; National Electrical Carbon Products, Inc.; Ian P. Norris; Robin D. Emerson; F. Scott Brown; and Jacobus Johan Anton Kroef.

${ }^{20}$ Le Carbone Lorrain S.A.; Carbone Lorraine North America Corporation; Carbone of America Industries Corp.

${ }^{21}$ Ludwig Schunk Stiftung e.V.; Schunk GmbH; Schunk Kohlenstoff-Technik GmbH; Schunk of North America, Inc.; Schunk Graphite Technology LLC; Hoffman \& Co. Elektrokohle AG; and Hoffman Carbon, Inc.

${ }^{22}$ SGL Carbon AG; and SGL Carbon, LLC.

${ }^{23}$ C. Conradty Nuernberg GmbH.

${ }^{24}$ In Re Electrical Carbon Products Antitrust Litigation, C.A. No. 1:03-cv-02182, Consolidated Third Amended Class Action Complaint, 2/12/2004 (N.J. 2003).

${ }^{25}$ Three Schunk Defendants, Schunk of North America, Inc., Hoffman Carbon, Inc. and Schunk Graphite

Technology, LLC; the Carbone Defendants; Morganite Industries, Inc.; Morgan Advanced Material \& Technology; National Electrical Carbon Products; The Morgan Crucible Company PLCand Morganite, Inc.

${ }^{26}$ In Re Electrical Carbon Products Antitrust Litigation, C.A. No. 1:03-cv-02182, Memo of Law in Support of Schunk of North America's, et al. Motion to Dismiss the Third Amended Complaint, 3/12/2004 (N.J. 2003); In Re Electrical Carbon Products Antitrust Litigation, C.A. No. 1:03-cv-02182, Memo of Law in Support of Carbone Defendants Motion to Dismiss the Third Amended Complaint, 3/12/2004 (N.J. 2003).

${ }^{27}$ In Re Electrical Carbon Products Antitrust Litigation, C.A. No. 1:03-cv-02182, Memo of Law in Support of Motion to Dismiss for Lack of Jurisdiction, 3/12/2004 (N.J. 2003).
} 
the statute of limitations. ${ }^{28}$ On May 19, 2004, SGL Carbon, LLC moved to dismissed for failure to state a claim and based on violation of the statute of limitations. ${ }^{29}$

On August 11, 2004, San Francisco BART voluntarily dismissed all claims. ${ }^{30}$ On August 27, 2004, the trial court denied all motions to dismiss before it. The trial court held that the complaint had alleged sufficient facts to state causes of action for claims of conspiracy and fraudulent concealment. ${ }^{31}$

On September 10, 2004, SGL Carbon, LLC and the Morgan Defendants filed their answers to the Consolidated Third Amended complaint. ${ }^{32}$ On September 17, 2004, Hoffman Carbon filed its answer. ${ }^{33}$

On October 19, 2004, the trial court granted the United States Government's motion to intervene. It also granted in part the government's motion for a stay in discovery. The court granted a stay of discovery of the lesser period of 90 days or the time when Defendant Ian Norris was extradited to the United States. The stay pertained only to the taking of depositions of those who had substantial contacts with Norris in connection with the charged crimes. ${ }^{34}$

\section{ii. Settlement}

\section{a. Carbone Defendants}

On August 13, 2004, the Carbone Defendants entered a proposed settlement agreement with the class plaintiffs. The Class ${ }^{35}$ was paid a total of $\$ 6$ million in damages. The first $\$ 3$ million dollars was deposited into an escrow account within five days after preliminary approval of the settlement. The second \$3 million was deposited into the account within five days after final approval of the settlement. ${ }^{36}$

Because of the settlement agreement, on August 16, 2004, the court dismissed without prejudice as moot the Carbone Defendant's motions to dismiss for failure to state a claim, violation of statute of limitations, and lack of personal jurisdiction. ${ }^{37}$

${ }^{28}$ In Re Electrical Carbon Products Antitrust Litigation, C.A. No. 1:03-cv-02182, Notice of Motion to Dismiss the Complaint on Behalf of Defendant Hoffman Carbon, Inc., 3/29/2004 (N.J. 2003).

${ }^{29}$ In Re Electrical Carbon Products Antitrust Litigation, C.A. No. 1:03-cv-02182, SGL Carbon, LLC's Notice of Motion to Dismiss the Complaint, 5/19/2004 (N.J. 2003).

${ }^{30}$ In Re Electrical Carbon Products Antitrust Litigation, C.A. No. 1:03-cv-02182, Notice of Voluntary Dismissal Without Prejudice, 8/11/2004 (N.J. 2003).

${ }^{31}$ In Re Electrical Carbon Products Antitrust Litigation, 333 F.Supp.2d 303, 314, 318 (N.J. 2004).

${ }^{32}$ In Re Electrical Carbon Products Antitrust Litigation, C.A. No. 1:03-cv-02182, Answer to Amended Complaint Third Consolidated Amended Class Action by SGL Carbon, LLC, 9/10/2004 (N.J. 2003); In Re Electrical Carbon Products Antitrust Litigation, C.A. No. 1:03-cv-02182, Answer to Third Consolidated Amended Class Action Complaint by Morgan Defendants, 9/10/2004 (N.J. 2003).

${ }^{33}$ In Re Electrical Carbon Products Antitrust Litigation, C.A. No. 1:03-cv-02182, Answer to Complaint, 9/17/2004 (N.J. 2003).

${ }^{34}$ In Re Electrical Carbon Products Antitrust Litigation, C.A. No. 1:03-cv-02182, Order Granting in Part and Denying in Party Motion for Stay, 10/19/2004 (N.J. 2003).

${ }^{35}$ The class was defined as "all person (excluding federal government entities, Defendants, and their respective parents, subsidiaries and affiliates) who purchased electrical carbon products in the United States, or from a facility located in the United States, directly from Defendants, their affiliates, subsidiaries or co-conspirators, during the period January 1, 1990, through December 31, 1999.”

${ }^{36}$ In Re Electrical Carbon Products Antitrust Litigation, C.A. No. 1:03-cv-02182, Proposed Settlement with Carbone Defendants, 8/13/2004 (N.J. 2003).

${ }^{37}$ In Re Electrical Carbon Products Antitrust Litigation, C.A. No. 1:03-cv-02182, Order Dismissing Motions to Dismiss Filed by Carbone Defendants, 8/16/2004 (N.J. 2003). 


\section{b. Morgan, Carbone, Schunk and SGL Defendants}

On April 15, 2005, the four groups of defendants filed a motion with the trial court for settlement of all claims. ${ }^{38}$

The first group was the Morgan Group. This group consisted of the following signatories to the agreement: The Morgan Crucible Company, PCL; Morganite Industries, Inc.; Morganite, Inc.; Morgan Advanced Materials and Technologies, Inc.; Morganite Electrical Carbon Ltd.; and National Electrical Carbon Products, Inc. The remaining Morgan Defendants were released under the agreement. The second group, the Carbone Group, consisted of the following signatories to the agreement: Le Carbone Lorraine, S.A.; Carbone Lorraine North America Corporation; and Carbone of America Industries Corporation. The third group consisted of the Schunk Defendants. Defendant SGL Carbon LLC made up the final group, with the agreement releasing claims against SGL Carbon $\mathrm{AG}^{39}$

Each group defined the class of plaintiffs as follows: "all persons (excluding federal government entities, defendants, and their respective parents, subsidiaries and affiliates) who purchased electrical carbon products in the United States, or from a facility located in the United States, directly from defendants, their affiliates, subsidiaries or co-conspirators, during the period January 1, 1990, through December 31, 1999."40

The Morgan Group agreed to pay $\$ 15$ million to be divided into three installments. The first installment, in the amount of $\$ 5$ million, was to be made within five business days after the date of preliminary approval of the settlement by the district court. The second installment, in the amount of $\$ 5$ million, was to be made within five business days after the date of the final approval of the settlement. The third installment, in the amount of \$5 million, was to be made within 90 days of the final approval of the settlement agreement. Attorney's fees were to be taken out of the settlement award. ${ }^{41}$

The Carbone Group agreed to pay $\$ 6$ million to be divided into two installments. The first installment of \$3 million was to be made within five business days after the date of preliminary approval of the settlement. The second installment, in the amount of \$3 million, was to be paid within five business days of the final approval of the settlement agreement. Attorney's fees were to be taken out of the settlement award. ${ }^{42}$ This award was later renegotiated down to $\$ 3.7$ million. $^{43}$

The Schunk Group agreed to pay $\$ 2.975$ million. Attorneys’ fees were to be taken out of the settlement award. ${ }^{44}$ The SGL Group agreed to pay the sum of $\$ 225,000$. Attorneys' fees were to be taken out of the settlement award. ${ }^{45}$

${ }^{38}$ In Re Electrical Carbon Products Antitrust Litigation, C.A. No. 1:03-cv-02182, Motion for Settlement, 4/15/2005 (N.J. 2003).

${ }^{39}$ In Re Electrical Carbon Products Antitrust Litigation, C.A. No. 1:03-cv-02182, Motion for Final Approval of Settlement, 9/29/2005 (N.J. 2003).

${ }^{40}$ In Re Electrical Carbon Products Antitrust Litigation, C.A. No. 1:03-cv-02182, Settlement Agreement Between Class Plaintiffs and Morgan Defendants, 4/15/2005 (N.J. 2003).

${ }^{41} I d$.

${ }^{42}$ In Re Electrical Carbon Products Antitrust Litigation, C.A. No. 1:03-cv-02182, Settlement Agreement Between Plaintiffs and Carbone Defendants, 8/11/2004 (N.J. 2003).

${ }^{43}$ In Re Electrical Carbon Products Antitrust Litigation, C.A. No. 1:03-cv-02182, Opinion, 8/30/2006 (N.J. 2003).

${ }^{44}$ In Re Electrical Carbon Products Antitrust Litigation, C.A. No. 1:03-cv-02182, Settlement Agreement Between Plaintiffs and Schunk Defendants, 12/17/2004 (N.J. 2003).

${ }^{45}$ In Re Electrical Carbon Products Antitrust Litigation, C.A. No. 1:03-cv-02182, Settlement Agreement Between

Plaintiffs and SGL Carbon, 4/15/2005 (N.J. 2003). 
The court gave preliminary approval of the settlement between the parties on May 5, $2005,{ }^{46}$ and final approval on August 30, 2006. ${ }^{47}$ The attorneys requested $25 \%$ in fees, not including costs and expenses, in the Morgan, Schunk and SGL settlements, and $331 / 3 \%$ in the Carbone settlement. ${ }^{48}$ Additionally, incentive awards for the class representatives were given. Five received an award of $\$ 12,000,{ }^{49}$ and two received an award of $\$ 6,000 .^{50}$

${ }^{46}$ In Re Electrical Carbon Products Antitrust Litigation, C.A. No. 1:03-cv-02182, Order Granting Preliminary Settlement Between Class Plaintiffs and Defendants, 5/11/2005 (N.J. 2003).

${ }^{47}$ In Re Electrical Carbon Products Antitrust Litigation, C.A. No. 1:03-cv-02182, Final Judgment Order Approving Settlements with All Named Defendants, 8/30/2006 (N.J. 2003).

${ }^{48}$ In re Elec. Carbon Products Antitrust Litigation, 622 F.Supp.2d 144, D.N.J.,2007

${ }^{49}$ SEPTA, NYC Transit Authority, Long Island Railroad, Metro North Commuter Railroad Company, and Lockwood Electric Motor Service of Trenton.

${ }^{50}$ BART, and City and County of San Francisco. 


\section{Ethylene Propylene Diene Monomer Antitrust Litigation ${ }^{1}$}

This case is notable because: (1) the plaintiffs received a total in damages of $\$ 107,245,000$; (2) the attorneys were awarded $\$ 17,829,000.00$ and expenses of $\$ 2,155,356.26$, or $21.7 \%$ of the total of the first four settlements of $\$ 82,245,000.00$; (3) and in the later settlement attorneys were awarded $\$ 8,322,500.00$ (33.33\% of the total) and costs $\$ 725,573.76 ;^{2}$ (3) the case involved two related criminal investigations. ${ }^{3}$

\section{A. Factual Background}

Ethylene Propylene Diene Monomoer (EPDM) is a synthetic rubber chemical compound, used primarily in the roofing and automotive industries. ${ }^{4}$ Because of the small number of producers, the market is considered concentrated. During the relevant period, January 1, 1997 to December 31, 2001, there were six "lockstep," industry-wide list price increases for EPDM. ${ }^{5}$

\section{B. Procedural Background}

In April 2003, the DOJ publicly announced investigations by itself, the European Commission ("EC") and the Canadian Competition Bureau ("CCB") into price fixing in the rubber chemicals market. ${ }^{6}$ Shortly thereafter thirteen class action lawsuits were filed throughout the country against the alleged EPDM cartel members. ${ }^{7}$ On August 11, 2003, all cases concerning the rubber chemical market were transferred to multi-district litigation in Connecticut. ${ }^{8}$ The presiding judge was Peter M. Dorsey until 2007, at which time he was recused for financial disqualification and Judge Stefan R. Underhill was assigned. ${ }^{9}$

On November 14, 2003, Plaintiffs filed a Consolidated Amended Class Action Complaint alleging that Defendants conspired at collusive meetings to maintain and fix list prices of EPDM in violation of Section 1 of the Sherman Act, taking turns raising prices to avoid suspicion. Prices in the U.S. were allegedly 10-15\% higher than the Western European market. Plaintiffs

\footnotetext{
${ }^{1} 681$ F.Supp.2d 141 (D. Conn. 2009)

2 For a summary of the first four settlements in this case, which totaled \$82,245,000.00, see Decl. of Anthony J. Bolognese, Esq. in Supp. of Pls.' Mot. for Interrum Award of Att'ys Fees \& Expenses, In re EPDM, No. 3:03md1542, Doc. \#373-3 (April 27, 2007) (hereafter "Declaration"). See also id., Doc. \#574 (Oct. 1, 2010) (ruling on attorneys fees and expenses regarding the final \$25 million settlement).

3 In re Ethylene Propylene Diene Monomer (EPDM) Antitrust Litigation, 681 F. Supp. 2d 141, 147 (D. Conn. Dec. 29, 2009) (order denying motion for summary judgment).

4 See id. at 147.

${ }^{5}$ Id.

${ }^{6}$ In 2006, the EC and DOJ closed their investigations without filing charges. See infra note 13. However, in denying summary judgment, the court ruled that the EC's interim factual findings from the investigation fell into a hearsay exception. See infra note 27.

${ }^{7} 681$ F. Supp. 2d at 147.

${ }^{8}$ Two MDL dockets were created. 3:03md1542 relates to EPDM. 3:05md1642 relates to the CR rubber chemical market. There was overlap between cartel members in both markets, and many pleadings and documents relate to both. See id. See also No. 3:05md1642, Doc. \#1 (Feb 18, 2005) (transfer order).

${ }^{9}$ In re EPDM, Case No. 3:03md1542, Doc. \#327 (Feb 8, 2007) (Order re: Recusal). Judge Peter Dorsey was nominated by President Ronald Reagan. Biographical Direcotry of Federal Judges, FEDERAL JUDICIAL CENTER, http://www.fjc.gov/servlet/nGetInfo?jid=638\&cid=999\&ctype=na\&instate=na Judge Stefan R. Underhill was nominated by President William J. Clinton. Id, at http://www.fjc.gov/servlet/nGetInfo?jid=2826\&cid=999\&ctype=na\&instate=na
} 
alleged that the cartel agreement was such that if a cartel member's production dropped due to plant problems its competitors would provide that cartel member with EPDM so that it could continue its supply, rather than face open competition for customers within the cartel. ${ }^{10}$ Two Defendants, Exxon and Dow, filed motions to dismiss, arguing that the Complaint's allegations were not sufficiently specific. While the motions to dismiss were pending, documentary discovery commenced, and Plaintiffs subsequently filled a Second Amended Complaint under seal. Exxon and Dow did not further pursue the motions to dismiss and the court denied them as moot. $^{11}$

In mid 2004, Defendant Crompton pled guilty and paid a \$50 million criminal fine and Bayer pled guilty and paid a \$66 million fine to charges against them relating to other chemical markets in the rubber chemicals industry, both involving collusive conduct relevant to the EPDM market. $^{12}$

During the course of discovery, over two million pages of documents were produced. ${ }^{13}$ In late 2005, Defendant Crompton answered Interrogatories to Plaintiffs, providing significant details as to the workings of the EPDM cartel. ${ }^{14}$ Documents related to the EC's EPDM investigation were produced, including the EC's interim factual findings, which were ruled admissible on a hearsay exception. ${ }^{15}$ Depositions were also taken, although Defendant's representatives pled the fifth to many questions. ${ }^{16}$

\section{i. $\quad$ Class Certification}

Class certification was heavily contested on the basis of market definition as there are several grades of EPDM and some private discounts were offered to customers deviating from the list price of EPDM set by the cartel. Multiple depositions were taken of experts on the issue of class certification and multiple motions were filed. Five settlement classes were certified between 2005 and 2009. In each case the certified class for settlement was direct purchasers of any grade of EPDM in the United States from January 1, 1997 to December 31, 2001for all grades of EPDM. ${ }^{17}$ In certifying the class, the court noted that a standardized pricing structure is sufficient to show common impact, even when there are variations in prices paid by customers. ${ }^{18}$

\section{ii. Settlements}

Four settlements with various Defendants occurred during 2005-2007. On May 10, 2007, an application for interim attorney's fees and expenses was granted, awarding attorney's fees of

\footnotetext{
${ }^{10}$ See id. at 148. Defendants included Bayer, Crompton, Syndial, Uniroyal, Dow, DSM, and Exxon (for brevity, informal names are used here).

11 See Declaration supra note 2, at 8.

${ }^{12}$ See Scott D. Hammond, An Overview of Recent Developments in the Antitrust Division's Criminal Enforcement Program, The United States DePARTMENT OF Justice, http://www.justice.gov/atr/public/speeches/207226.htm (January 10, 2005)

${ }^{13}$ See Declaration supra note 2, at 9.

${ }^{14} \mathrm{Id}$. at 12.

${ }^{15} \mathrm{Id}$. at 13 . For the ruling on admissibility, see infra note 27.

${ }^{16}$ In re EPDM, 681 F. Supp. 2d at 150 (Dec. 29, 2009) (Order denying motion for summary judgment).

${ }^{17}$ See Declaration supra note 2, at17.

${ }^{18}$ See Hal J. Singer \& Robert Kulick, Class Certification in Antitrust Cases: An Economic Framework, 17 GEO. MASON L. R. 1035, 1047 (discussing EPDM); Joshua Davis \& Eric L Cramer, Antitrust, Class Certification, and the Politics of Procedure, 17 GEO. MASON L. R. 969, at n. 94 (2010) (citing EPDM for this proposition).
} 
$\$ 17,829,000.00$ and expenses of $\$ 2,155,356.26$, or $21.7 \%$ of the total of the first four settlements of $\$ 82,245,000.00 .{ }^{19}$ The remaining Defendants, referred to as the "DSM Defendants," filed a motion for summary judgment and to strike certain evidence, including the EC's interim factual findings as well as the Answers to Interrogatories of Defendant Crompton, the fourth Defendant to settle. The court ruled that Interrogatory Answers had "equivalent circumstantial guarantee[s] of trustworthiness to other out-of-court statements excepted from the hearsay rule" and fell into a hearsay exception under FRE 807 (the "catch-all" exception). ${ }^{20}$ The EC interim factual findings were ruled to be trustworthy as they were "the final report by the investigatory body of the Commission" and excluded from the hearsay rule under FRE 803(8)(C) (investigatory reports). ${ }^{21}$ The court denied the motion for summary judgment and to strike on December 29, $2009 .^{22}$

On September 20, 2010, following negotiations, the court approved a settlement between Plaintiffs and remaining Defendants for \$25 million. On October 10, 2010, the court approved an award of attorney's fees of \$8,322,500.00 (33.33\%) and costs \$725,573.76 from that final settlement. ${ }^{23}$

As the EC and DOJ closed their investigations of the EPDM market in 2006 without filing charges, the recovery by private plaintiffs represents the only recovery for customers between 1997 and 2002. ${ }^{24}$

${ }^{19}$ In re EPDM, No. 3:03md1542, Doc. \#377 (May 10, 2007).

${ }^{20}$ In re EPDM, 681 F. Supp. 2d at 152-153.

${ }^{21}$ Id. at $155-160$.

${ }^{22} \mathrm{Id}$.

${ }^{23}$ In re EPDM, No. 3:03md1542, Doc. \#574 (Oct. 1, 2010) (ruling on attorneys fees and expenses regarding the final \$25 million settlement).

${ }^{24}$ In re EPDM, 681 F. Supp. 2d at 147. 


\section{High Pressure Laminates Antitrust Litigation ${ }^{1}$}

This case is notable because: (1) the plaintiffs in the direct-purchaser class received a total recovery of $\$ 41$ million; (2) the plaintiffs in the indirect-purchaser class received a total recovery of $\$ 5,225,785$; (3) the plaintiffs' attorneys were awarded $\$ 13$ million in fees, plus $\$ 3,570,570$ for expenses (overall $33.3 \%$ ), and the named plaintiffs received $\$ 130,000$ in incentive awards.

\section{A. Factual Background}

"HPL” or high pressure laminates are composite structures composed of multiple layers of melamine-impregnated paper, foil or plastic bonded together on the top with resin infused paper under pressure which are heated to form a single sheet or panel. During the class period the HPL industry was highly concentrated, there were only four major domestic manufacturers in the United States. Wilsonart had the highest market share of the four companies, followed by Formica, International Paper and Pioneer. The manufacturers sold HPL directly to direct account purchasers, independent distributers and through company-owned distributors. The plaintiffs claimed that the four manufacturers conspired to fix prices in the United States. ${ }^{2}$

\section{B. Procedural Background}

This litigation was brought against the following manufacturers of High Pressure Laminates ("HPLs") under Section 1 of the Sherman Act: International Paper Company (which sold high pressure laminates through its subsidiaries, including Nevamar); Panolam International, Inc.; Pioneer Plastics Corporation; Premark International, Inc., and Wilsonart International (collectively, the "Defendants") and Formica Corporation. ${ }^{3}$ There were two class actions in this case. One set of plaintiffs ${ }^{4}$ were direct purchasers of HPL from the defendants and Formica Corporation and their respective subsidiaries. ${ }^{5}$ Another set of plaintiffs were indirect purchasers of HPLs. ${ }^{6}$

The direct Plaintiffs' Complaint ${ }^{7}$ alleged that the defendants violated federal antitrust law by conspiring to raise, fix, and maintain the prices of HPL sold in the United States during a

\footnotetext{
${ }^{1}$ Civil File No. 00-MDL-1369. Judge: Hon. Charles L. Brieant. Jurisdiction: United States District Court, Southern New York MDL 1368. Complaint Filed on February 22, 2001.

${ }^{2}$ Memorandum and Order, In re High Pressure Laminates Antitrust Litigation, No. 00-MD-1368 (S.D.N.Y. September 8, 2004), Doc. 227

3 The settlement for Formica was later discharged in bankruptcy.

${ }^{4}$ The Plaintiffs are: Samantha Wilson d/b/a Wilson's Flooring \& Interiors, Ives Design, Ajax Philadelphia, Inc., EasternPlywood Corporation, Plywood Plastics, Glen Stanley d/b/a Custom Cabinets, Dakota Wood Design, Decolam, Inc., Jaeckle Wholesale, Inc., Schiller Custom Cabinetry, Inc., and Constructive Art, Inc. d/b/a/ Custom Creations.

${ }^{5}$ The direct class of purchasers was defined as "All persons who directly purchased high pressure laminates in the United States from any of the Defendants or any subisdiary thereof, or from Formica Corporation or any subsidiary thereof, at any time during the period from January 1, 1994 to June 30, 2000. ”

${ }^{6}$ Indirect purchasers were defined as "a person or entity: (1) who bought HPL manufactured or sold by Defendants from someone other than Defendants or their subsidiaries or affiliates, or (2) who purchased an HPL-Containing Product."

${ }^{7}$ The Consolidated Class Action Complaint was filed in this action on February 22, 2001 on behalf of the Plaintiffs (the “Complaint”).
} 
period from January 1, 1994, through June 30, 2000. They claimed that, as a result of the alleged conspiracy, they and other purchasers of HPL were injured by paying more for HPL than they would have paid in the absence of allegedly illegal conduct. The plaintiffs sought the recovery of treble damages, attorney's fees, and other relief. The defendants denied the allegations in the complaint, denied any liability, and denied that any plaintiff or member of the Class was entitled to damages or other relief. ${ }^{8}$ On June 17,2003 , the court ordered that this action be maintained as a class action and certified a class of direct purchasers. ${ }^{9}$

On February 9, 2004, Defendants Wilsonart, Premark, International Paper Company (“IP) and Panolam moved individually and jointly for summary judgment. On September 7, 2004 the court granted summary judgment as to Premark, but denied summary judgment as to defendant Wilsonart. The court had previously approved a settlement between the Class Plaintiffs and IP on July 14, 2004. An order approving a preliminary settlement between the Class Plaintiffs and defendants Panolam and Pioneer was approved on July 30, 2004, staying the motions of those defendants. ${ }^{10}$

\section{i. $\quad$ Settlement}

\section{a. Direct Purchasers}

Direct purchaser plaintiffs eventually entered into settlement agreements with several of the defendants. On April 23,2004, defendant International Paper Company ("IPC”) settled for the amount of $\$ 31,000,000 .{ }^{11}$ Later that year, Pioneer and Panolam also settled and agreed to pay $\$ 9,500,000$. $^{12}$

\section{b. Indirect Purchasers}

Indirect purchasers of HPL's were also able to secure settlement agreements with defendant's IPC, Panolam and Pioneer. On July 27, 2004 IPC entered into an agreement to pay $\$ 4,000,000$ to the indirect purchasers of HPL. ${ }^{13}$ On December 2, 2004, Panolam and Pioneer settled for the amount of $\$ 1,225,785$ to the indirect purchaser class action.

\section{c. Cy Pres Distribution of Residual Settlement Fund}

On May 17, 2011 the court ordered that the residual amount of money in the settlement fund, amounting to $\$ 41,644.79$, would be paid to Habitat for Humanity International. ${ }^{14}$

\footnotetext{
${ }^{8}$ Defendants answered the Complaint on April 5, 2001.

${ }^{9}$ Memorandum and Order, In re High Pressure Laminates Antitrust Litigation, No. 00-MD-1368 (S.D.N.Y.

September 8, 2004), Doc. 227

${ }^{10}$ Id.

${ }^{11}$ IPC Settlement Agreement dated April 23, 2004.

12 Pioneer/Panolma Settlement Agreement dated July, 27, 2004.

${ }^{13}$ Master Settlement Agreement Between Settlement Classes and Defendant International Paper Company. Second

Cir. Court for Davidson County, Tenn. 20 ${ }^{\text {th }}$ Judicial Dist. Nashville. Civil Action No. 00C-1989

${ }^{14}$ Order Directing Cy Pres Distribution of Residual Settlement Fund, In re High Pressure Laminates Antitrust

Litigation, No. 00-MD-1368 (S.D.N.Y. September 8, 2004), Doc. 392.
} 


\section{ii. Wilsonart Trial}

The Class Plaintiffs' claims against Wilsonart, the only remaining defendant after prior settlements and summary judgment, went to trial on April 10, 2006. On April 28, 2006 Wilsonart moved for a judgment as a matter of law. However, the court denied the motion finding that the Plaintiffs presented evidence over and above mere parallelism. The court concluded that the Plaintiff's showed the existence of plus-factors, "which, when viewed in conjunction with the parallel price movement, can serve to allow the jury to find that the Plaintiffs have presented evidence that tends to exclude the possibility that Wilsonart acted independently, and that it is more likely that not that an agreement to fix prices existed. "15

On May 24, 2006 the jury returned a verdict for the defense. ${ }^{16}$ The court entered a final judgment on the jury verdict on July 19, 2006 stating that the action was to "be dismissed on the merits as to that defendant."17

\section{iii. Judge}

The judge who presided over the case is the Honorable Charles L. Brieant of the U.S. District Court, Southern New York. He was nominated by President Richard Nixon.

\footnotetext{
${ }^{15}$ Order Denying Motion for Judgment as a Matter of Law. In re High Pressure Laminates Antitrust Litigation, 2006 WL 1317023 at *2 (S.D.N.Y. July 19, 2006) (No. 00 MD1368 (CLB)). Doc. 352.

${ }^{16}$ Jury Verdict, In re High Pressure Laminates Antitrust Litigation, No. 00-MD-1368 (S.D.N.Y. May 24, 2006). The actual Jury Verdict is not available; however, other sources indicate the jury found only that the plaintiffs had not proven that Wilsonart participated in a conspiracy, not that there was no conspiracy. See http://apps.americanbar.org/antitrust/at-committees/at-trial/jury-instructions/15.shtml.

${ }^{17}$ Final Judgment on Jury Verdict, In re High Pressure Laminates Antitrust Litigation, No. 00-MD-1368 (S.D.N.Y. July 19, 2006). Doc. 365
} 


\section{Intel Corp. Microprocessor Antitrust Litigation ${ }^{1}$}

This case is notable because (1) AMD and Intel settled for $\$ 1.25$ billion in cash; ${ }^{2}$ (2) Judge Farnan dismissed AMD's allegations involving "foreign commerce," effectively limiting damages in the case to transactions and customers related to the U.S. market; ${ }^{3}$ (3) in a related European Union ("EU”) case, Intel was charged by the European Commission ("EC"), eventually found in violation, and on May 13, 2009 fined 1.06 billion euros, which Intel is in the process of appealing. ${ }^{4}$

\section{A. Procedural Background}

The origin of AMD's allegations against Intel, and its support for those allegations, are unclear. Intel has been the subject of a long string of government and private suits for more than 20 years. As AMD is Intel's only real competitor, AMD has had a part to play in much, if not most, of that litigation either as plaintiff, complainant, or witness. ${ }^{5}$ The Japan Fair Trade Commission ("JFTC"), EC and Federal Trade Commission ("FTC") all were conducting investigations of Intel prior to and/or during AMD's filing of the Delaware action that settled on Nov. 11, 2009. It is difficult, if not impossible, to determine the origin of each of AMD's allegations in 2005, let alone each specific item of evidence supporting those allegations. However, AMD states the JFTC's investigation of Intel was a "trigger" for its lawsuit. ${ }^{6}$ On April 8, 2004, the JFTC raided Intel's offices in Japan for alleged violations of Japanese antimonopoly law by offering rebates to its customers for the exclusive use of Intel processors. ${ }^{7}$ No fine was issued, but in early March, 2005, the Japanese warned Intel in the form of a set of written "recommendations" to cease certain practices in its customer dealings. Intel stated it did not agree with, but would abide by, the JFTC's recommendations. ${ }^{8} \quad$ Sometime before June, 2004, the EC issued 64 letters of inquiry regarding simliar allegations, prompted by an AMD complaint. $^{9}$

${ }^{1}$ MDL Docket No. 05-1717-JJF, 2005 WL 1838069 (D. Del. 2009).

${ }^{2}$ Settlement Agreement Between Advanced Microdevices Inc. and Intel Corporation, p.1 (Nov. 11, 2006), available at http://download.intel.com/pressroom/legal/AMD settlement_agreement.pdf (last visited Nov. 10, 2010) (hereafter, Settlement Agreement).

${ }^{3}$ In re Intel, No. 05-1717-JJF, Document 279 (D. Mass. Sep. 26, 2006).

${ }^{4}$ European Comission Fines Computer Chipmaker \$1.45 Billion, DIGITALBIZ, May 13, 2009, http://www.cnn.com/2009/BUSINESS/05/13/europe.intel.anti.trust/. Intel's Chief Executive Speaks Out Against \$1.45 Billion Fine for Antitrust Violations, VENTUREBEAT, May 13, 2009, http://venturebeat.com/2009/05/13/intelslapped-with-145-billion-fine-for-antitrust-violations/. See also EU Omsbudsman Faults EC's Intel Antitrust Ruling, Nov. 18, 2009,

http://www.techworld.com.au/article/326816/eu_ombudsman_faults_ec intel_antitrust_ruling/?fp=512\&fpid=15053 24106\&rid=1 (regarding criticisms of shoddy evidence management during the EC's long investigation of Intel).

${ }^{5}$ Intel and AMD: A Long History in Court, CNET NEWS, June 28, 2004, http://news.cnet.com/Intel-and-AMD-A-

long-history-in-court/2100-1014_3-5767146.html?tag=mncol;txt.

${ }^{6}$ Analysis: AMD Takes Gloves Off in Battle with Intel, COMPUTERWORLD, June 28, 2005,

http://www.computerworld.com/s/article/102832/Analysis_AMD takes gloves_off_in battle_with_Intel.

${ }^{7}$ Antitrust Office in Japan Raids Intel Branch, Seeking Files, N.Y. TIMES, April 9, 2004,

http:/query.nytimes.com/gst/fullpage.html?res=9D0DE7D81538F93AA35757C0A9629C8B63.

${ }^{8}$ Japan Antitrust Watchdog Bites Intel, CNET NEWS, March 8, 2005, http://news.cnet.com/Japan-antitrustwatchdog-bites-Intel/2100-1014_3-5603204.html?tag=mncol;txt.

${ }^{9}$ EU Revisits Intel Probe, CNET NEWS, June 8, 2004, http://news.cnet.com/EU-revisits-Intel-probe/2100-1014_35228652.html?tag=mncol;txt. This investigation later led to several indictments, and finally a 1.06 billion euros fine on May 13, 2009, discussed at infra note 25. 
On June 27, 2005, AMD filed a complaint against Intel in the U.S. District Court of Delaware for violations of Section 2 of the Sherman Act as well as $\S 17045$ of the California Business and Professions code related to anticompetitive pricing and interference with a prospective advantage, ${ }^{10}$ including the following notable allegations: 1 . Intel forced nearexclusive deals by conditioning rebates on foregoing purchases from AMD, 2. Intel threatened retaliation against customers introducing AMD platforms; 3. Intel established quotas requiring retailers to stock Intel near-exclusively; 4: Intel forced PC makers to boycott AMD; and 5. Intel forced industry technical standards that handicap AMD in the marketplace. ${ }^{11}$ The complaint states that Intel enjoyed an $80 \%$ share of the market measured by units. ${ }^{12}$ AMD alleges Intel's conduct unlawfully served to maintain and enhance its monopoly in the x86 microchip market. ${ }^{13}$ The complaint specifically references the JFTC recommendations. ${ }^{14}$

On June 30, 2005, AMD also filed two lawsuits against Intel in Japan. Although Intel and AMD included the Japanese suit in their settlement of the Delaware action, the Japanese complaints sought a total of only $\$ 105$ million plus interest, less than $1 \%$ of $\$ 1.25$ billion paid to AMD by Intel. ${ }^{15}$

On July 12, 2005, a consumer class-action suit was filed on behalf of Intel customers in the x86 microprocessor market, also in U.S.D.C. of Delaware. ${ }^{16}$ This class action was consolidated with $A M D v$. Intel for purposes of discovery. Judge Joseph J. Farnan, Jr. presided over the consolidated case. In 2010, after the settlement of AMD v. Intel, the court denied class certification. $^{17}$

On March 7, 2007, Judge Farnan dismissed the "foreign commerce" portions of AMD's Delaware complaint on the basis that the U.S. court had no subject matter based on the Foreign Trade Antitrust Improvements Act of 1982. This effectively limited damages in the case to only those transactions and customers related to the U.S. market. However, the court did not restrict the scope of discovery, upholding the special master's discovery decision that foreign conduct was relevant to proving AMD's domestic claims. ${ }^{18}$ Intel moved the court to order AMD to strictly define its cause of action and limit the scope of discovery accordingly, but on June 25, 2009, the court denied Intel's motion on the basis that definition of a strict legal basis for its cause of action would implicate factual questions that could not be answered until after discovery was completed. $^{19}$ Intel also filed a motion to dismiss AMD's claims related to exported commerce. However, the motion was still pending at the time of settlement. ${ }^{20}$

\footnotetext{
${ }^{10}$ See Complaint, supra note 1 , at 43-46.

${ }^{11}$ See Complaint, supra note 1 , at 2 .

12 See id.

${ }^{13}$ See Complaint, supra note 1 , at $43-44$.

${ }^{14}$ See e.g. Complaint, supra note 1, at 16 ("In proceedings brought by the JFTC, Intel has accepted the JFTC charges of misconduct with respect to Sony.").

${ }^{15}$ See Settlement Agreement, supra note 4.

${ }^{16}$ Paul v. Intel Corp., 05-485-JJF.

${ }^{17}$ See In re Intel Corp. Microprocessor Antitrust Litigation, MDL Docket No. 05-1717-JJF, Document 2471, (July 28, 2010) (Special Master's Recommendation); Intel Wins Ruling in Class-Action Case, THE WALL STREET JoURNAL, July 29, 2010, http://online.wsj.com/article/SB10001424052748703578104575397630555706878.html.

${ }^{18}$ In re Intel, No. 05-1717-JJF, 476 F.Supp.2d 452 (March 7, 2007).

${ }^{19}$ In re Intel, No. 05-1717-JJF, Document 279, 2009 WL 1885666, 2009-2 Trade Cases P 76, 678.

${ }^{20}$ In re Intel, No. 05-1717-JJF, Document 2254 (Nov. 18, 2009) (Letter from Intel counsel to Judge Farnan).
} 


\section{i. International Legal Action}

In June, 2008, South Korea fined Intel \$25 million, which Intel appealed. ${ }^{21}$ This was following a February 2006, raid by the SKFTC on Intel's offices in South Korea. ${ }^{22}$ In February, 2008, the EC raided Intel offices in Munich related to their 2000 investigation of AMD's complaints. ${ }^{23}$ Intel was charged, and eventually found in violation, and on May 13, 2009 was fined 1.06 billion euros, about $\$ 1.45$ billion, which is pending on appeal. ${ }^{24}$

\section{ii. Settlements}

On November 11, 2009, AMD and Intel reached a settlement agreement, as a condition of which AMD dismissed the Delaware suit and both of the Japanese suits. Intel agreed to pay AMD $\$ 1.25$ billion in cash within 30 days, which it did. ${ }^{25}$ Included in the settlement was the renegotiated agreement regarding several patent license agreements and the releases of mutual allegations of patent license breaches, which were not included in any lawsuit. In addition, Intel agreed to abide by certain sales and marketing practices when dealing with customers, retailers, distributors, and end users, as specified by the settlement agreement. Intel further agreed not to induce customers to introduce design elements which reduced the performance of AMD products. In addition to dismissing its suits, AMD agreed to cease participation in all administrative or regulatory actions against Intel. ${ }^{26}$

The settlement required no court approval, although the parties stipulated as a condition of dismissal that the court would retain the power to enforce the provisions of the settlement and the protective orders regarding discovery, all of which the Judge approved in signing the order dismissing the case. ${ }^{27}$ No benefits were recovered from foreign defendants for purposes of this study (i.e., from firms headquartered or principally owned or operated outside of the U.S.).

Although AMD's private suit against Intel was only one of many private and public actions against Intel regarding these or similar allegations of illegal pricing, rebates, and customers dealings, the $\$ 1.25$ billion fine is the largest amount actually recovered from the company to date, since the EC fine is still being appealed. All of the cash settlement in this case

\footnotetext{
${ }^{21}$ South Korea Regulators Fine Intel \$25 Million, CNET NEWs, June 4, 2008, http://news.cnet.com/8301-10784_39960491-7.html.

${ }^{22}$ Korean Antitrust Regulators Raid Intel, BETANEws, Feb. 9, 2006, http://www.betanews.com/article/Korean-

Antitrust-Regulators-Raid-Intel/1139514055.

${ }^{23}$ European Commission Raids Intels Offices in Munich, INFOWoRLD, Feb. 12, 2008,

http://www.infoworld.com/d/security-central/european-commission-raids-intel-offices-in-munich-328.

${ }^{24}$ European Comission Fines Computer Chipmaker \$1.45 Billion, DIGITALBIZ, May 13, 2009, http://www.cnn.com/2009/BUSINESS/05/13/europe.intel.anti.trust/. Intel's Chief Executive Speaks Out Against $\$ 1.45$ Billion Fine for Antitrust Violations, VentuREBEAT, May 13, 2009, http://venturebeat.com/2009/05/13/intelslapped-with-145-billion-fine-for-antitrust-violations/. See also EU Omsbudsman Faults EC's Intel Antitrust Ruling, Nov. 18, 2009,

http://www.techworld.com.au/article/326816/eu ombudsman faults ec intel antitrust ruling/?fp=512\&fpid=15053 24106\&rid=1 (regarding criticisms of shoddy evidence management during the EC's long investigation of Intel).

${ }^{25}$ Intel Forks over the $\$ 1.25$ billion to AMD, apparently it just has it 'laying around,' AOL TECH, Dec. 11, 2004, http://www.engadget.com/2009/12/11/intel-forks-over-the-1-25-billion-settlement-to-amd-apparently/.

${ }^{26}$ See Settlement Agreement supra note 4. For an interesting narrative of how the settlement agreement between the companies was negotiated, see The Intel and AMD Settlement: A Play-by-Play, Businessweek, http://www.businessweek.com/technology/content/nov2009/tc20091115 692400.htm.

${ }^{27}$ In re Intel, No. 05-1717-JJF, Document 2262 (D. Mass. December 1, 2009).
} 
went directly to AMD; nothing was distributed directly to customers. ${ }^{28}$ No specific award for attorney's fees was included in the settlement agreement. ${ }^{29}$ President Ronald Reagan appointed presiding Judge Farnan. ${ }^{30}$ I found no comment by Judge Farnan or special master Poppoti on the performance of the attorneys in this case. As evidenced by this study, there was a large amount of media attention, attributable no doubt in part to the size of the settlement and markets involved. $^{31}$

\section{iii. Related Legal Actions}

Two days after the AMD v. Intel settlement, on November 13, 2009, a shareholder derivative suit was filed against Intel alleging that the company's antitrust violations breached a fiduciary duty to its shareholders. The suit settled May 29, 2010 and was approved shortly thereafter by Judge Farnan, who presided over $A M D v$. Intel, as well. The settlement required intel to incorporate a series of corporate governance reforms, much of which was related to AMD's allegations against Intel. ${ }^{32}$

On December 16, 2009, the U.S. FTC filed suit against Intel as well on similar charges. $^{33}$ The suit with the FTC settled August, 2010, with no money changing hands, but Intel agreed to adhere to yet further provisions regarding governance. ${ }^{34}$

Th $\$ 1.25$ billion probably represents a lower bound of the value of Intel's antitrust harm to AMD because Intel was alleging patent violations against AMD, which were dropped as part of the settlement and probably lowered the cash value AMD collected. Although AMD was alleging patent violations against Intel as well, these were retalitory, largely based on the claim that Intel's allegations of AMD's patent infringement were in bad faith, which would be considered a violation in and of itself under the terms of the companies' agreements. Secondly, the settlement included a renegotiation of Intel and AMD's patent cross-license agreements, from which AMD received the better part of the bargain. ${ }^{35}$

${ }^{28}$ See Settlement Agreement supra note 4.

${ }^{29}$ Id.

${ }^{30}$ Farnan, Joseph James Jr., Biographical Directory of Federal Judges, FedERAL Judicial Center, http://www.fjc.gov/servlet/nGetInfo?jid=735\&cid=999\&ctype=na\&instate=na (last accessed, November 11, 2010).

${ }^{31}$ AMD v. Intel has also been referenced or discussed in numerous scholarly articles. The Delaware case was notable for the enormous amount of electronic discovery conducted, and an incident involving what Intel claims was the inadvertent deletion of emails, which continued even as discovery progressed. Intel discovered this company-

wide practice of deletion in violation of the judge's discovery orders and brought it to the attention of the court itself. See, e.g., 832 PLI/lit 283 (Sep. 20, 2010).

32 In re Intel corp. Derivative Litigation, Case No. 1:09-cv-00867-JFF, Document 51 (May 25, 2010, D. Delaware) (Stipulation of Settlement).

${ }^{33}$ FTC Sues Intel, But Has the Horse Already Escaped From the Barn?, THE WALL StREET JournAL, Dec. 16, 2009, http://blogs.wsj.com/law/2009/12/16/ftc-sues-intel-but-has-the-horse-already-escaped-from-the-barn/.

${ }^{34}$ Chipmaker Intel Settles FTC Antitrust Suit, BBC News, Aug. 4, 2010, http://www.bbc.co.uk/news/business10870840 .

${ }^{35}$ AMD, Intel x86 Patent Fight Likely to be Long and Messy, ARS TECHNICA, March 16, 2009, http://arstechnica.com/hardware/news/2009/03/amd-intel-engaged-in-x86-licensing-staredown.ars. 


\section{Polyester Staple Antitrust Litigation ${ }^{1}$}

This case is notable because: (1) the parties settled for $\$ 60.95$ million; (2) the attorneys representing plaintiffs' claims were awarded \$ 19,468,444.56 million for fees, costs, and expenses they incurred (overall 32\%); and (3) related to the litigation were two different criminal investigations, among other government agency hearings.

\section{A. Factual Background}

Polyester Fiber is defined as a "man-made, synthetic polymer fiber derived from polyethylene terephthalateand composed of linear macromolecules in the chain at least $85 \%$ by mass of an ester of diol and terephthalic acid." 2 This fiber is then cut into specific length that are "relatively limited but spinnable," which is generally about .5 to 4-6 inches. ${ }^{3}$ The cut fiber is referred to as "polyester staple," or PSF. Manufacturers use PSF in several applications. Fiberfill for pillows, mattresses, furniture cushions, comforters, jackets, and sleeping bags is created from PSF, as are carpets. ${ }^{4}$ PSF is also used as a spinnable fiber for use in both woven and nonwoven applications. ${ }^{5}$ Each application uses certain types of PSF, thus requiring different cutting procedures to produce different characteristics.

The characteristics of a type of PSF will determine its application. PSF is described by a list of characteristics, including "denier (thickness and weight of the fiber), cut length, crosssectional shape, tenacity (strength), dyeability, pilling performance (the tendency of fibers to accumulate on a fabric's surface), elongation, shrinkage, and spinning compatibility."6 Both plaintiffs and defendants agreed that PSF manufactured for one purpose is generally not suitable for use in another manufacturing industry. ${ }^{7}$ These characteristics are considered in connection with a more important factor for purchases of PSF.

For most PSF, price is one of the most important criteria for a purchaser in choosing which producer they wish to purchase from. ${ }^{8}$ This may depend in part on whether the PSF is considered "commodity-like" or "specialty." PSF will be classified as "specialty" if the fibers are not easily duplicated or are produced mostly on smaller scales by commodity manufacturers. ${ }^{10}$

Most types of PSF are manufactured on the same basic production line, using special hardware added to the line to control desired characteristics and properties of the PSF. ${ }^{11}$ A typical manufacturing process would go: "polymerization, extrusion, application of finish, drawing, imparting crimp and heat setting, and cutting." ${ }^{2}$ However, regardless of the end use,

1 , C.A. No. 3:03-1516 (W.D.N.C. 2008).

${ }^{2}$ In re Polyester Staple Antitrust Litigation, C.A. No. 03-1516, Order Granting Class Plaintiffs’ Motion for Class Certification Pursuant to Fed. R. Civ. P. 23, 7/19/2007, at 3.

${ }^{3} I d$.

${ }^{4}$ Id. at 4 .

${ }^{5} I d$.

${ }^{6} I d$.

${ }^{7}$ See id. at 5 ("It is undisputed that PSF products designed for end use in one of these customer categories generally are not suitable for use in other categories." (internal quotations emitted)).

${ }^{8} I d$.

${ }^{9} I d$.

${ }^{10} \mathrm{Id}$.

${ }^{11} I d$. at 6-7.

${ }^{12} \mathrm{Id}$. at 7. 
both commodity and specialty PSF are made from the same raw materials, consisting of at least 85\% polyethyleneterephthalate. ${ }^{13}$ Therefore, PSF with certain characteristics and physical properties does not differ from manufacturer to manufacturer, allowing interchangeability between brands. ${ }^{14}$

PSF is usually the most important input in the application for which it is used, without having any close substitutes. ${ }^{15}$ Along with having a high-demand market, in 1994, four producers of PSF accounted for 87\% of the North American market: Arteva, Wellman, DuPont, and Nan Ya America. ${ }^{16}$ In 2000, the same four manufacturers accounted for $81 \%$ of the North American market, with Arteva as the largest producer, then Wellman, DAK entities (including DuPont), and finally Nan Ya. ${ }^{17}$

Prices for PSF are not generally known or accessible to the public. This is because the manufacturers of PSF do not usually distribute price lists for their products. ${ }^{18}$ The normal practice was for customers to pay the pricing method provided by the manufacturer. ${ }^{19}$ What pricing method was offered varied "from customer-to-customer (and sometimes product-byproduct) depending on a number of factors, including the volume being purchased and the prior dealings/nature of business relationship between the manufacturer and purchaser," causing

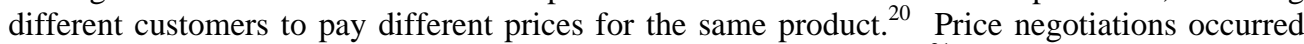
with each individual purchaser, particularly with the large customers. ${ }^{21}$

The price of PSF began to falter in the late 1990s. In 1996, the price began to fall continually through $1999 .^{22}$ Starting in 1999, and continuing through 2001, manufacturers experienced "substantial excess capacity." 23 This was being caused by textiles from China being shipped into the United States, causing a lack of demand for carpets from national carpet manufacturers for carpets, leading to a lack of demand for PSF. ${ }^{24}$ Customers of PSF manufacturers were "routinely filing for bankruptcy" and shutting down their plants, continuing to drive down the demand for PSF. ${ }^{25}$ Despite the state of the industry, starting in mid-1999, the price of PSF ceased declining and began to rise through mid-2001. ${ }^{26}$

Between June 28, 1999 and June 30, 1999, the first price increase occurred with each of the four largest manufacturers raising their overall prices for PSF 10-15\%. ${ }^{27}$ Along with the announcement of the raising of prices was the reasoning behind the raises, namely increases in the costs of raw materials. ${ }^{28}$ The second price increase took place between October 1, 1999, and October 5, 1999, with another raise of 10-15\% from Arteva, DuPont and Nan Ya. The third

\footnotetext{
${ }^{13} I d$. at 6 .

${ }^{14} \mathrm{Id}$. at 7.

${ }^{15}$ Id. at 8-9.

${ }^{16} I d$. at 9.

${ }^{17} \mathrm{Id}$.

${ }^{18} I d$.

${ }^{19} \mathrm{Id}$.

${ }^{20} \mathrm{Id}$.

${ }^{21} \mathrm{Id}$. at 10 .

${ }^{22} \mathrm{Id}$.

${ }^{23} \mathrm{Id}$.

${ }^{24}$ Id.

${ }^{25} I d$.

${ }^{26} I d$.

${ }^{27} \mathrm{Id}$. at 14 .

${ }^{28} \mathrm{Id}$.
} 
price increase took place between January 10, 2000, and January 14, 2000, with another raise of 10-15\% from DuPont, Arteva, Nan Ya and Wellman.

\section{B. Related Actions}

By the Fall of 2000, the U.S. Department of Justice Antitrust Division began an investigation of criminal violations of federal antitrust laws by producers of PSF. ${ }^{29}$ In an attempt to limit its criminal and civil liability, Defendant DuPont admitted that it and/or its subsidiaries, agents and affiliates participated in a conspiracy to fix prices and allocate customers in the PSF industry, gaining immunity from prosecution in the process. $^{30}$ A resulting investigation produced an indictment of Robert Dutton, a former sales manager of Defendant Nan Ya America, for the conspiracy to fix prices and allocate customers in the PSF industry. ${ }^{31}$ Defendant Arteva/KoSa was charged with conspiring to violate the Sherman Antitrust Act, 15 U.S.C. $\S 1$, to which they ultimately plead guilty on December 18, 2002. ${ }^{32}$ Arteva was given a monetary fine in the amount of $\$ 28,500,000.00 .^{33}$ Defendant Troy F. Stanley additionally was indicted by a grand jury and plead guilty on December 18, 2002, to violating antitrust laws by fixing prices and allocating customers in the PSF industry. ${ }^{34}$ Stanley agreed to pay a criminal fine of $\$ 20,000$ and serve an eight month prison sentence ${ }^{35}$

Arteva also faced criminal charges in Canada. On August 6, 2003, the Canadian Attorney General formally charged Arteva with violating Section 45(1)(c) of the Competition Act. $^{36}$ As with the U.S. Department of Justice proceeding, Arteva admitted to many of the charges, including announcing prices at agreed ranges in order to increase prices. ${ }^{37}$

In addition to the criminal convictions, a civil case was filed by Defendant KoSa and its parent company, Koch Industries, Inc., against the corporate defendants in the PSF litigation for fraud in connection with the 1998-1999 sale of their polyester business assets to Koch. ${ }^{38}$ This case is currently still pending, under the caption Koch Industries, Inc., et al. v. Hoechst Aktiengesellschaft, et al., C.A. No. 03-8679 (S.D.N.Y. 2003).

Executive agencies were involved in administrative proceedings due to the admissions of antitrust violations. On August 2, 1999, Nan Ya America, Arteva, and Wellman jointly filed an Antidumping Duty Petition with the U.S. International Trade Commission based on allegations that low cost fiberfill from Taiwanese, Chinese, and other Asian importers were being “dumped”

\footnotetext{
${ }^{29}$ Burlington Industries, LLC, et al. v. CNA Holdings, Inc., et al., C.A. No. 3:06-387, Amended Consolidated Complaint, 10/10/2006, at 41.

${ }^{30}$ In re Polyester Staple Antitrust Litigation, C.A. No. 03-1516, Consolidated Amended Class Action Complaint, $7 / 17 / 2003$, at 64 .

${ }^{31} \mathrm{Id}$. at 65.

${ }^{32}$ Id. at 67.

${ }^{33}$ In re Polyester Staple Antitrust Litigation, C.A. 03-1516, Order Granting Class Plaintiffs’ Motion for Class Certification Pursuant to Fed. R. Civ. P. 23, 7/19/2009, at 16.

${ }^{34}$ In re Polyester Staple Antitrust Litigation, C.A. No. 03-1516, Consolidated Amended Class Action Complaint, $7 / 17 / 2003$, at 66 .

${ }^{35} \mathrm{Id}$.

${ }^{36}$ In re Polyester Staple Antitrust Litigation, C.A. No. 03-1516, Order Granting Plaintiffs’ Motion for Class Certification, 7/19/2007.

${ }^{37}$ Id.

${ }^{38}$ Burlington Industries, LLC, et al. v. CNA Holdings, Inc., et al., C.A. No. 06-387, Consolidated Complaint, 9/11/2006, at 46 .
} 
in the U.S. causing the prices to drop, affecting U.S. markets. ${ }^{39}$ As a result, in May 2000, the ITC issued a ruling granting an imposition of various restrictions and duties up to fourteen percent on Korean and Taiwanese imports. ${ }^{40}$ But after Arteva admitted to the antitrust allegations, in March 2006, the ITC commenced proceedings for the purpose of reconsidering its earlier ruling. ${ }^{41}$ The ITC did not revoke its prior ruling, finding that the fine denier PSF market involved in the antitrust conspiracy was not affected by the ruling, and that the revocation might lead to a continuance or recurrence of material injury to domestic partners. ${ }^{42}$

Before the class litigation beginning, the class plaintiffs and other entities/individuals filed their own separate claim in district courts. These cases were spread across eight different districts, yet all included the same nucleus of defendants. In the interest of efficiency, a multidistrict litigation panel convened and decided to transfer the cases to the Western District of North Carolina to be tried by Judge Richard L. Voorhees, ${ }^{43}$ the same judge who presided over

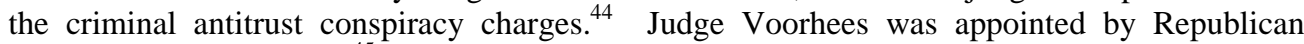
President Ronald Reagan. ${ }^{45}$

\section{Procedural History}

The antitrust class litigation involved direct purchasers of polyester staple from the Class Defendants. The ten named class plaintiffs filed a consolidated amended class action complaint in the Western District of North Carolina on July 17, 2003. ${ }^{46}$ The ten entities were as follows: Hollander Home Fashions Corporation; Carpenter Company; Tex Tech Industries, Inc.; Fiber Dynamics, Inc.; Doran Mills, LLC; Habasit Belting, Inc.; J.H.N.Y., Inc.; Thomaston Mills, Inc.; Quality Felt Co.; and Southern Fiber, Inc. ${ }^{47}$ Plaintiffs claimed that the defendants violated Sections 4 and 16 of the Clayton Act, 15 U.S.C. $\S \S 15$ and 26, and Section 1 of the Sherman Act, 15 U.S.C. $\S 1 .^{48}$ The alleged violation would be per se. The Class Defendants constituted four distinct groups, referred to as the Nan Ya Defendants, ${ }^{49}$ the Wellman Defendant, ${ }^{50}$ the KoSa Defendants, $^{51}$ and the DAK Defendants. ${ }^{52}$ A total of 42 other entities or individuals filed cases

${ }^{39}$ In re Polyester Staple Antitrust Litigation, C.A. No. 03-1516, Order Granting Plaintiffs’ Motion for Class Certification, 7/19/2007, at 18-19.

${ }^{40} I d$. at 19.

${ }^{41} I d$.

${ }^{42}$ Id. at $19-20$.

${ }^{43}$ In re Polyester Staple Antitrust Litigation, C.A. No. 03-1516, Multidistrict Litigation Panel Transfer Order

${ }^{44}$ Burlington Industries, LLC, et al. v. CNA Holdings, Inc., et al., C.A. No. 06-387, Amended Consolidated Complaint, 10/10/2006, at 42 .

${ }^{45} \mathrm{http} / / /$ en.wikipedia.org/wiki/Richard_Voorhees

${ }^{46}$ In re Polyester Staple Antitrust Litigation, C.A. No. 03-1516, Consolidated Amended Class Action Complaint, $7 / 17 / 2003$.

${ }^{47} I d$.

${ }^{48}$ In re Polyester Staple Antitrust Litigation, C.A. No. 03-1516, Order Granting Class Plaintiffs' Motion for Class Certification Pursuant to Fed. R. Civ. P. 23, at 1-2.

${ }^{49}$ The Nan Ya Defendants are: Nan Ya Plastics Corporation, Taiwan; Nan Ya Plastics Corporation, America a/k/a Nan Ya Plastics Corporation USA; and Robert Bradley Dutton. In re Polyester Staple Antitrust Litigation, C.A. 031516, Consolidated Amended Class Action Complaint, 7/17/2003, at 17-19.

${ }^{50}$ The Wellman Defendant is Wellman, Inc. Id. at 20.

${ }^{51}$ The KoSa Defendants are: Arteva Specialties, S.a.r.l. d/b/a KoSa; Arteva Specialties LLC; Arteva Services S.a.r.l.; Troy F. Stanley; Koch Industries, Inc.; and IMASAB S.A. de C.V. Id. at 21-27. Arteva Specialties is headquartered in Mexico.

${ }^{52}$ The DAK Defendants are: DAK Fibers LLC; DAK Americas LLC; E..I. DuPont de Nemours \& Co.; and Alpek S.A. de C.V. Id. at 28-31. 
related to the class litigation, and they included other entities and individuals as defendants in their litigation.

On April 5, 2004, the court granted a motion by the Department of Justice to stay the litigation pending further action by the Federal Grand Jury investigating possible criminal violations of the antitrust laws in the Polyester Staple industry. ${ }^{53}$ All depositions, interrogatories, and requests for admissions that were pending at the time of the order were stayed until August 5 , 2004, or until the grand jury made a decision, whichever occurred first. ${ }^{54}$ On July 29, 2004, the court filed an order further staying the litigation based upon Defendant Wellman, Inc.'s status as a target in the grand jury investigation. ${ }^{55}$ Therefore, with the exception of documents already under review, all discovery was further stayed through October 5, 2004, including both class certification and merits discovery. ${ }^{56}$

Two motions to dismiss were filed by parties. The first was a motion to dismiss the consolidated class action complaint under Rule 12(b)(6) for failure to state a claim. ${ }^{57}$ This motion was filed prior to the filing of an answer to the consolidated class action complaint. On August 5, 2004, before both Twombly and Iqbal, the court denied the motion. ${ }^{58}$ The second was a motion to dismiss under Rules 129b)(2) and (5) and notice of intent to rely on foreign law and request for judicial notice. $^{59}$ This motion was filed prior to the filing of an answer to the consolidated class action complaint. On September 23, 2004, before both Twombly and Iqbal, the court denied the motion. ${ }^{60}$

The motion for class certification was granted by the court on July 19, 2007. ${ }^{61}$ The motion was granted after discovery and during pre-trial preparation, with only the KoSa Defendants remaining and all other defendants having settled with plaintiffs.

Below, the remainder of the litigation will be described in four separate sections, each dealing with a separate defendant sub-group.

\section{i. DAK Defendants}

During litigation, several of the plaintiffs in cases related to the class litigation voluntarily dismissed their claims against the DAK Defendants. Shortly after filing of the consolidated amended class action complaint, the DAK Defendants were the first defendants to settle with the class. On August 27, 2003, all four DAK Defendants signed and filed a proposed settlement agreement with the Class Plaintiffs. $^{62}$ The settlement occurred prior to the filing of an answer to

${ }^{53}$ In re Polyester Staple Antitrust Litigation, C.A. No. 03-1516, Order Staying Discovery Until Conclusion of Grand Jury Investigation, 4/5/2004.

${ }^{54} \mathrm{Id}$.

${ }^{55}$ In re Polyester Staple Antitrust Litigation, C.A. No. 03-1516, Order Further Staying Class Certification and

Discovery Because of Grand Jury Investigation, 7/30/2004.

${ }^{56}$ Id.

${ }^{57}$ In re Polyester Staple Antitrust Litigation, C.A. No. 03-1516, Order Denying Koch Industries’ Motion to Dismiss, $8 / 5 / 2004$

${ }^{58} I d$.

${ }^{59}$ In re Polyester Staple Antitrust Litigation, C.A. No. 03-1516, Order Denying Nan Ya Taiwan’s Motion to Dismiss, 9/23/2004.

${ }^{60} \mathrm{Id}$.

${ }^{61}$ In re Polyester Staple Antitrust Litigation, C.A. No. 03-156, Order Granting Plaintiffs' Motion for class Certification, 7/19/2007.

${ }^{62}$ The proposed settlement agreement only lists seven of the ten plaintiffs. In re Polyester Staple Antitrust Litigation, C.A. No. 03-1516, Proposed Settlement Agreement With DuPont and DAK Defendants, 8/27/2003, at 
the consolidated amended class action complaint. The Class ${ }^{63}$ was paid $\$ 17.15$ million for settlement of the action. ${ }^{64}$ The court gave preliminary approval of the settlement between the parties on September 18, 2003, ${ }^{65}$ and final approval on May19, 2004. ${ }^{66}$ In granting final approval, the court relied heavily upon Co-Lead Counsel's assessment that the settlement was an "excellent result.",67

The plan for allocation provided that class members would receive a pro rata share of the Settlement Fund after costs and fees had been removed, and can qualify for their share by filing timely proof of claims forms. ${ }^{68}$ The claim shares were calculated based on the dollar amount each class member paid to defendants for its direct purchase of PSF from the Defendants during the period August 1, 1999 through July 31, 2001. ${ }^{69}$ The plan for allocation was approved by the court on September 30, 2004. ${ }^{70}$

The settlement agreement did not provide for any attorneys' fees or cost, but stated that any fees or costs awarded by the court were to come from the Settlement Fund. ${ }^{71}$ On motion from plaintiffs' counsel, on September 30, 2004, the court awarded fees in the aggregate amount of $\$ 3,425,000.00$ or $20 \%$ of the fund, plus costs incurred by them on behalf of the Class in the aggregate amount of $\$ 500,000.00$ from the fund, and interest on attorneys' fees and costs awarded at the same rate of interest earned by the fund from the date of deposit until the date of payment. $^{72}$

\section{ii. Wellman Defendant}

During the litigation, many of the cases related to the class litigation dismissed their claims against Wellman, Inc. ("Wellman"). Around two years after the filing of the consolidated amended class action complaint, Wellman became the second defendant group to sign a settlement agreement with the class plaintiffs on September $7,2005 .^{73}$ The settlement occurred prior to filing an answer to the consolidated amended class action complaint. The Class ${ }^{74}$ was

pg. 1. The absent class plaintiffs had not dismissed or settled their claims, so this omission may not be material, as the settlement includes them by referring to the class purchasers. Id.

63 “All individuals or entities who purchased Polyester Staple in the United States directly from any of the

Defendants or their co-conspirators or any predecessor, subsidiary or affiliate of each, at any time during the period from April 1, 1999 to July 31, 2001.” Id. at 1, 13.

${ }^{64} \mathrm{Id}$. at 21.

${ }^{65}$ In re Polyester Staple Antitrust Litigation, C.A. No. 03-1516, Order Granting Motion for Preliminary Approval of Proposed Settlement with DAK Defendants, 9/18/2003.

${ }^{66}$ In re Polyester Staple Antitrust Litigation, C.A. No. 03-1516, Order Granting Final Approval of Proposed Settlement with DAK Defendants, 5/19/2004.

${ }^{67}$ Id. at 9.

${ }^{68}$ In re Polyester Staple Antitrust Litigation, C.A. No. 03-1516, Memorandum in Support of Plaintiffs' Motion for Approval of Proposed Plan of Allocation, 5/28/2004, at 2-3.

${ }^{69}$ Id.

${ }^{70}$ In re Polyester Staple Antitrust Litigation, C.A. No. 03-1516, Order Approving Plan of Allocation, 9/30/2004.

${ }^{71}$ In re Polyester Staple Antitrust Litigation, C.A. No. 03-1516, Proposed Settlement Agreement With DuPont and DAK Defendants, 8/27/2003, at 28.

${ }^{72}$ In re Polyester Staple Antitrust Litigation, C.A. No. 03-1516, Order Awarding Attorneys' Fees and Costs in Connection with the DAK Settlement, 9/30/2004, at 2.

${ }^{73}$ In re Polyester Staple Antitrust Litigation, C.A. No. 03-1516, Notice of Proposed Settlement with Nan Ya Defendants and Wellman Defendants, 10/5/2005, at 3.

74 “'Wellman Settlement Class' means all person and entities who purchased Polyester Staple in the United States directly from any of the Defendants or their alleged co-conspirators or any predecessors, subsidiaries or affiliates of each at any time during the period from April 1, 1999 through July 31, 2001. Excluded from the class are all 
paid $\$ 6,800,000.00$ for settlement of the action, with the amount being reduced on a pro rata basis based upon the ratio of the total number of pounds purchased during the Class Period by any and all Wellman Opt-Outs to the total number of pounds purchased by the Wellman Settlement Class during the Class period, and with the difference returned to Wellman. ${ }^{75}$ The court gave preliminary approval of the settlement between the parties on October $5,2005,{ }^{76}$ and gave final approval on December $15,2005 .^{77}$ In granting final approval, the court claimed that attorneys' work was fair and competent in representing the interests of the class. ${ }^{78}$

The plan for allocation was approved on September 26, 2006. ${ }^{79}$ The plan provided that $\$ 33,411$ was to be retained by the escrow agent for the payment of taxes and preparation costs, followed by the transfer of the settlement fund to the Claims Administrator for approved claims within the class. ${ }^{80}$

During settlement, the parties agreed to an amount for attorneys' fees to be worked into the settlement agreement. On September 16, 2005, Plaintiffs' counsel were given $\$ 1,700,000.00$ for attorneys' fees and costs incurred during the litigation. ${ }^{81}$

\section{iii. Nan Ya Defendants}

During litigation, many of the cases related to the class litigation dismissed their claims against the Nan Ya Defendants. Around a week after Wellman settled with the Class, the Nan Ya Defendants became the third defendant group to sign a settlement agreement on September 16, 2007. ${ }^{82}$ The settlement occurred prior to filing an answer to the consolidated amended class action complaint. The Class ${ }^{83}$ was paid $\$ 4,000,000.00$ for settlement of the action, with the amount being reduced on a pro rata basis based upon the ratio of the total number of pounds purchased during the Class Period by any and all Nan Ya Opt-Outs to the total number of pounds purchased by the Nan Ya Settlement Class during the Class Period, and the difference being returned to Nan Ya. ${ }^{84}$ The court gave preliminary approval of the settlement between the parties

governmental entities, the Defendants, and their respective parents, predecessors, subsidiaries, affiliates, and their alleged co-conspirators and the Non-Class Plaintiffs. Also excluded are Wellman Opt-Outs.” Id.

${ }^{75}$ Id. at 1 .

${ }^{76}$ In re Polyester Staple Antitrust Litigation, C.A. No. 03-1516, Order Granting Preliminary Approval of Proposed Settlement with Wellman, Inc., 10/5/2005.

${ }^{77}$ In re Polyester Staple Antitrust Litigation, C.A. No. 03-1516, Order and Rule 54(b) Final Judgment as to Wellman, Inc., 12/15/2005.

${ }^{78} \mathrm{Id}$. at 4

${ }^{79}$ In re Polyester Staple Antitrust Litigation, C.A. No. 03-1516, Order Authorizing Distribution of Settlement Funds, 9/26/2006.

${ }^{80}$ In re Polyester Staple Antitrust Litigation, C.A. No. 03-1516, Order Authorizing Distribution of Settlement Funds, $9 / 26 / 2006$, at 1.

${ }^{81}$ In re Polyester Staple Antitrust Litigation, C.A. No. 03-1516, Notice of Proposed Settlement with Nan Ya Defendants and Wellman Defendants, 10/5/2005, at 1.

${ }^{82}$ In re Polyester Staple Antitrust Litigation, C.A. No. 03-1516, Notice of Proposed Settlement with Nan Ya Defendants and Wellman Defendants, 10/5/2005, at 2.

83 “' Nan Ya Settlement Class' means all person and entities who purchased Polyester Staple in the United States directly from a Defendant or any of their predecessors, subsidiaries or affiliates from April 1, 1999 through July 31, 2001. Excluded from the Class are all governmental entities, the Defendants and their respective parents, subsidiaries, affiliates and their alleged co-conspirators and the Non-Class Plaintiffs. Also excluded are the Nan Ya Opt-Outs." Id. at 2.

${ }^{84} \mathrm{Id}$. at 4. 
on October 5, 2005, ${ }^{85}$ and gave final approval on December 15, $2005 .^{86}$ In granting final approval, the court claimed that attorneys' work was fair and competent in representing the interests of the class. ${ }^{87}$

The plan for allocation was approved on September 26, 2006. ${ }^{88}$ The plan provided that the escrow agent would retain $\$ 36,453$ for the payment of taxes or tax preparation costs until the Class Counsel directed that it be transferred to the Claims Administrator for approved claims within the Class. ${ }^{89}$

During settlement, the parties agreed to an amount for attorneys' fees to be worked into the settlement agreement. On September 16, 2005, Plaintiffs' counsel were given $\$ 1,000,000.00$ for attorneys' fees and costs incurred during the litigation. ${ }^{90}$

\section{iv. KoSa Defendants}

During litigation, the Class Plaintiffs and the KoSa Defendants agreed to mediation, which the court granted through motion on December 7, 2005. ${ }^{91}$ Most of the cases related to the class litigation dismissed their claims against the KoSa Defendants. After years of litigation with the Class, KoSa became the fourth and final defendant group to sign a settlement agreement on March 13, 2008. ${ }^{92}$ The settlement occurred after filing an answer to the consolidated amended class action complaint, and after discovery had been completed, during trial preparation. The Class ${ }^{93}$ was paid $\$ 33,000,000.00$ for settlement of the action, ${ }^{94}$ with each named Class Plaintiff being awarded $\$ 10,000$ in addition to their settlement share to be paid from the Settlement Fund. ${ }^{95}$ The court gave preliminary approval of the settlement between the parties on April 15, $2008,{ }^{96}$ and gave final approval on June $24,2008 .^{97}$

The allocation plan distributed the proceeds of the settlement, net of all fees, expenses and awards, on a pro rata basis among the Class based on the total dollars spent on Polyester Staple directly purchased from the KoSa Defendants during the period August 1, 1999 through

${ }^{85}$ In re Polyester Staple Antitrust Litigation, Order Granting Preliminary Approval of Proposed Settlement with the Nan Ya Defendants, 10/5/2005.

${ }^{86}$ In re Polyester Staple Antitrust Litigation, C.A. No. 03-1516, Order and Rule 54(b) Final Judgment as to Nan Ya Defendants, 12/15/2005.

${ }^{87}$ Id. at 4.

${ }^{88}$ In re Polyester Staple Antitrust Litigation, C.A. No. 03-1516, Order Authorizing Distribution of Settlement Funds, 9/26/2006.

${ }^{89} \mathrm{Id}$. at 1 .

${ }^{90}$ In re Polyester Staple Antitrust Litigation, C.A. No. 03-1516, Notice of Proposed Settlement with Nan Ya Defendants and Wellman Defendants, 10/5/2005, at 1.

${ }^{91}$ In re Polyester Staple Antitrust Litigation, C.A. No. 03-1516, Stipulation and Order Granting Mediation, $12 / 7 / 2005$.

${ }_{92}$ In re Polyester Staple Antitrust Litigation, C.A. No. 03-1516, Notice of Settlement by KoSa, 4/1/2008.

93 “All individuals or entities (excluding governmental entities, Defendants, and their parents, predecessors, subsidiaries, affiliates, and their co-conspirators and Opt-Outs) who purchased Polyester Staple in the United States directly from any of the Defendants or their co-conspirators or any predecessor, subsidiary or affiliate of each, at any during the period from April 1, 1999 to July 31, 2001.” In re Polyester Staple Antitrust Litigation, C.A. No. 031516, Order Granting Preliminary Approval of Proposed Settlement with KoSa, 4/15/2008, at 2.

${ }_{94}$ In re Polyester Staple Antitrust Litigation, C.A. No. 03-1516, Order and Final Judgment, 6/24/2008, at 9.

${ }^{95} \mathrm{Id}$. at 11.

${ }^{96}$ In re Polyester Staple Antitrust Litigation, C.A. No. 03-1516, Order Granting Preliminary Approval of Proposed Settlement with KoSa, 4/15/2008.

${ }^{97}$ In re Polyester Staple Antitrust Litigation, C.A. No. 03-1516, Order and Final Judgment, 6/24/2008. 
July 31, 2001. ${ }^{98}$ No comment by the court was made as to the adequacy of the work done by class counsel.

The settlement agreement did not provide for any attorneys' fees or costs. On June 24, 2008, when granting final approval of the settlement, the court awarded Class Counsel 33\% of the Settlement Fund $(\$ 11,000,000.00)$ and $\$ 1,843,444.56$ for costs, plus interest earned thereon, out of the Settlement Fund. ${ }^{99}$

\section{v. Other Actions}

In Richards v. Arteva Specialties, an indirect purchaser suit was brought against the same defendants. However, the trial court upheld the defendants' motion to dismiss for failure to state a claim. The plaintiff appealed the decision and the court of appeals reversed the trial court's decision. ${ }^{100}$

${ }^{98}$ In re Polyester Staple Antitrust Litigation, C.A. No. 03-1516, Memorandum in Support of Motion for Preliminary Approval of Settlement Agreement With KoSa, 4/11/2008, at 6.

${ }^{99}$ In re Polyester Staple Antitrust Litigation, C.A. No. 03-1516, Order and Final Judgment, 6/24/2008, at 10.

${ }^{100}$ Richards v. Arteva Specialties, 66 Mass.App.Ct. 726, 850 N.E.2d 1068 (App. Ct. Mass. 2006). 


\section{Molecular Diagnostics Labs. v. Hoffmann-La Roche Inc. ${ }^{1}$}

This case is notable because: (1) the parties settled for \$33 million; (2) the plaintiffs' attorneys were awarded 33.3\% of the settlement with interest; (3) the plaintiffs' attorneys were reimbursed over \$3 million in reimbursement for costs and expenses they incurred; (4) the court awarded MDL an additional \$40,000 as an incentive award for being the named plaintiff; (5) the litigation established that direct purchasers of goods have standing to pursue Walker Process claims; and (6) the litigation established that the statute of limitations for purchasers' claims is tolled under a continuing violation theory.

\section{A. Factual Background}

Polymerase chain reaction ("PCR") is a technique used to copy a DNA sequence and produce many copies of the sampled DNA, and the large quantity of DNA enables researchers to study and manipulate the DNA sequence. ${ }^{2}$ To make these copies, PCR uses polymerases - which are enzymes that produce copies of a DNA sequence. ${ }^{3}$ During the PCR process, the polymerases and DNA sample are subjected to rapid fluctuations between extreme heat and lower temperatures called cycling. ${ }^{4}$ Many of the polymerases ordinarily cannot survive the exposure to the heat extremes during cycling, so researchers in the past needed to add more polymerases at the beginning of each cycle. ${ }^{5}$

However, in the 1960s scientists discovered Thernus aquaticus, which is a bacterium that can survive exposure to higher temperatures. ${ }^{6}$ Beginning in the 1970 s, scientists began trying to isolate a Thermus aquaticus polymerase (Taq), which was documented in various publications. ${ }^{7}$ Cetus Corporation, as part of a joint venture with Perkin-Elmer Applied Biosystems ("PE”), received a patent on Taq in 1989. ${ }^{8}$ Two years later, Hoffman La-Roche ("Roche") purchased Cetus's PCR division and then assumed Cetus's role in the joint venture with PE. Applera Corporation also holds rights to the Taq patent because the company entered into joint venture agreements on PCR research. ${ }^{10}$ One of these joint venture agreements includes a partnership between Applera and Roche "to develop, market, and sell PCR-related products."11

\section{B. Procedural Background}

On September 23, 2004, Molecular Diagnostics Laboratories (“MDL”) filed a class action complaint against Hoffman La-Roche, Perkin-Elmer Applied Biosystems, and Applera Corporation (collectively "the Defendants") ${ }^{12}$ under 15 U.S.C. $\S \S 1$ and 2 for restraint of trade,

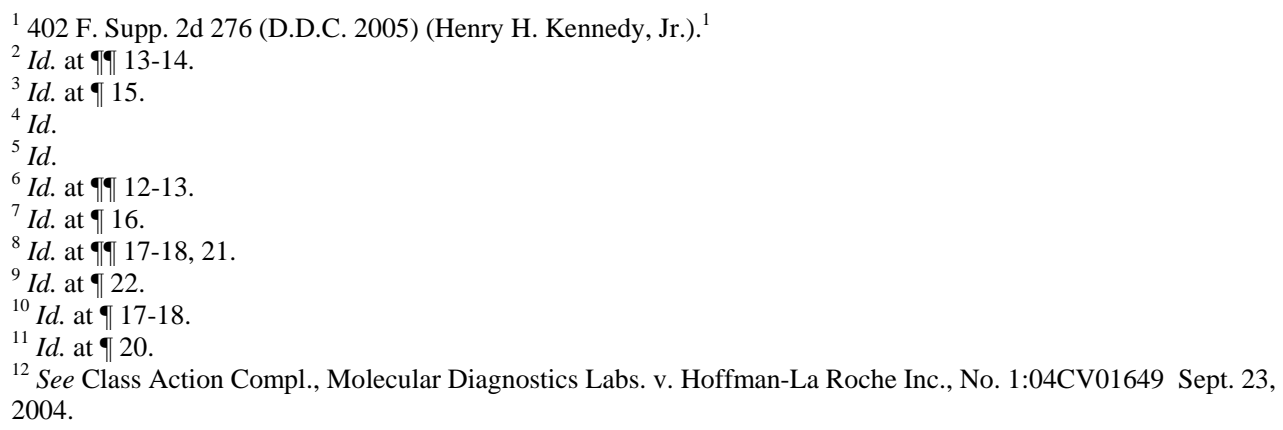


monopolization and conspiracy to monopolize. ${ }^{13}$ MDL alleged that the Defendants' engaged in "anticompetitive conduct related to Thermus aquaticus DNA polymerase" ("Taq") that caused MDL to pay "supracompetitive prices for Taq and PCR-related products." 14 According to MDL, the Defendants "developed a variety of schemes and agreements to stifle competition and to injure and overcharge" consumers of PCR related products, and that the Defendants filed actions for infringement based on the Taq patent. ${ }^{15}$ Further, MDL alleged that the Taq patent was "obtained by misconduct through a series of material misstatements and omissions to PTO, made with the intent to deceive the PTO."16

MDL alleged that the Defendants fraudulently submitted their applications in 1986 and 1987, that the Defendants never performed the experiments listed in the application, "never obtained results stated in the applications, and then concealed their misrepresentations." 1988, the PTO rejected all claims to the application stating that the subject matter was anticipated under 35 U.S.C. $\S 102$ and obvious under 35 U.S.C. $§ 103 .{ }^{18}$ In March 1989, the Defendants allegedly submitted a response letter to the PTO "materially misrepresenting facts, omitting specific and important contrary data, misstating scientific principles, misrepresenting the content of prior art, and falsely reporting data." 19

In 1999, Promega successfully challenged the validity of the Taq patent after Roche sued Promega for breach of contract in $1993 .^{20}$ The California District Court judge found that "intentional misstatements and omissions before the PTO had led to the issuance of the patent," and that named inventors and corporate counsel falsely represented material facts to the PTO, which rendered the patent unenforceable. ${ }^{21}$ Roche appealed and the Federal Circuit affirmed and

${ }^{13}$ Id. at 9 ๆ $57-70$.

${ }^{14}$ Id. at 9 १ा 1-2, 61 .

${ }^{15} \mathrm{Id}$. at 9 १ $36,37$.

${ }^{16}$ Id. at $\uparrow 25$.

${ }^{17} \mathrm{Id}$. at 930 .

${ }^{18}$ Id. at 927 .

${ }^{19} \mathrm{Id}$. at 929.

${ }^{20}$ See Hoffmann-La Roche, Inc. v. Promega Corp., No. C-93-1748 VRW, 1999 WL 1797330 *1 ๆ 3 (N.D. Cal. Dec. $7,1999)$ (hereinafter Roche I).

${ }^{21}$ Compl. ๆ 38-39; see Roche I, $1999 \mathrm{WL}$ at *9 ๆ 71, *28, *24 ๆ 185, *24 ๆ 2.The court stated that "[t]he findings of fact and conclusions of law ... demonstrate that the [Taq] patent was procured by inequitable conduct.” Roche I, 1999 WL at *28. Specifically, the court found that Promega demonstrated by clear and convincing evidence that the applicants for the patent committed inequitable conduct by:

(1) withholding material information in their possession that Taq does not bind, or binds only weakly, to phosphocellulose columns;

(2) making misleading statements regarding the relative fidelity of Taq as compared to the prior art enzymes;

(3) claiming that Taq purified by the method taught in Example VI had a specific activity of $\bullet 250,000$ units/mg;

(4) presenting Example VI as though it had been performed when, in fact, it had not been performed; (5) making deceptive, scientifically unwarranted comparisons between the specific activity of the claimed enzyme and the specific activity reported by Chien et al. and Kaledin et al.;

(6) withholding information in applicants' possession that Taq interacts with matrices used in size exclusion chromatography;

(7) claiming that Taq purified according to the method taught in Example VI yielded a single $\bullet 88 \mathrm{kd}$ band on an SDS PAGE mini-gel and

(8) claiming that the Taq produced was free from nuclease contamination. 
remanded. ${ }^{22}$ On remand, the District Court again ruled that the patent was unenforceable. ${ }^{23}$ Following the Roche III ruling, MDL then filed against the Defendants. ${ }^{24}$

For MDL's claims of monopolization and conspiracy to monopolize, it alleged that Roche and Applera "achieved dominance in the market for Taq and ... exercised their power in that market." ${ }^{25}$ MDL further alleged that, without the fraudulently received patent, the Defendants would have been subject to competition in the Taq market. ${ }^{26}$ For MDL's claim for restraint of trade, it alleged that Roche and Applera's conduct "resulted in the unlawful tying of separate PCR-related products" and the two companies entered into numerous agreements not to compete and allocating the market. ${ }^{27}$

In response to MDL's allegations, the Defendants moved to dismiss because MDL lacked standing to sue, the statute of limitations had run, and for various other reasons. ${ }^{28}$ First, the Defendants argued that MDL did not have standing to sue because the company filed the class action complaint on behalf of consumers, and that consumers do not have standing to sue for alleged Walker Process violations. ${ }^{29}$ Second, the Defendants argued that the statute of limitations on the action had already run because "MDL was on notice of the alleged fraud perpetrated against the PTO" on December 7, 1999 (the date after the California district court issued the Roche I decision), ${ }^{30}$ or alternatively, that the action did not qualify under a continuing violation theory because Walker Process claims are not continuing violations. ${ }^{31}$

Judge Henry H. Kennedy, Jr. denied the Defendants' motion to dismiss, finding that MDL had standing to sue, and that the action was filed within the statute of limitations. ${ }^{32}$ Kennedy first stated that MDL had standing to sue because "[a] Walker Process claim is not a fraud claim . . ., but an antitrust violation. The harm is not the invalid patent, but the use of the invalid patent to establish a monopoly." ${ }^{, 33}$ Judge Kennedy held that direct purchasers are preferred plaintiffs because of the ease of apportioning damages; and furthermore, if the primary purpose of treble damages is deterrence, then increasing the number of parties that scrutinize a potential monopolist's conduct will aid in deterring such conduct. ${ }^{34}$ Therefore, because "direct

Id. "Each of the foregoing misstatements and each item of information withheld was material to the prosecution of the application that led to issuance of the [Taq] patent." Id. Furthermore, each "was made with an intent to mislead the PTO or with such recklessness as to afford no inference other than that they were made with an intent to deceive. ... All claims of the [Taq] patent are therefore unenforceable." Id. All but two of these findings were upheld by the Federal Circuit. Compl. \ 40; see also Roche II and Roche III.

${ }^{22}$ Hoffmann-La Roche, Inc. v. Promega Corp., 323 F.3d 1354, 1366 (Fed. Cir. 2003) (hereinafter Roche II).

${ }^{23}$ Hoffman-La Roche, Inc. v. Promega Corp., 319 F. Supp. 2d 1011, 1013 (N.D. Cal. 2004) (hereinafter Roche III).

${ }^{24}$ Roche III, 319 F. Supp. 2d at 1013.

${ }^{25}$ Compl. ๆ 59.

${ }^{26}$ Id.

${ }^{27}$ Id. at $968,67$.

${ }^{28}$ See Molecular Diagnostics Labs. v. Hoffmann-La Roche Inc., 402 F. Supp. 2 d 276 (D.D.C. 2005).

${ }^{29}$ Molecular Diagnostics Labs., 402 F. Supp. 2d at 279.

${ }^{30}$ Id. at 282, 283; see Roche I, 1999 WL 1797330.

${ }^{31}$ Molecular Diagnostics Labs., 402 F. Supp. 2d at 285.

${ }^{32}$ See id.

${ }^{33}$ Id. at 280.

${ }^{34} I d$. at 282, 281. The "legislative purpose in creating a group of 'private attorneys general' to enforce the antitrust laws under $\S 4$ is better served by holding direct purchasers to be injured to the full extent of the overcharge paid by them than by attempting to apportion the overcharge among all that may have absorbed a part of it." Illinois Brick Co. v. Illinois, 431 U.S. 720, 734-35 (1977). 
purchasers have standing to pursue Walker Process claims," the court ruled that MDL had standing to sue. ${ }^{35}$

Second, Kennedy acknowledged that MDL was on notice of the lawsuit against the Taq patent after Roche I, and not after Roche III as was asserted by MDL. ${ }^{36}$ However, under a continuing violation theory Kennedy ruled that the statute of limitations had not run because MDL brought the suit as a purchaser of Taq and not a competitor. ${ }^{37}$ The complaint did not allege that the enforcement of the patent was MDL's injury, but that the "injury arose through the payment of supra-competitive prices resulting from an illegitimately obtained monopoly on Taq." ${ }^{38}$ The distinction is important because "a monopolist's rival may be injured at the time the anticompetitive conduct occurs," while a purchaser "is not harmed until the monopolist actually exercises its illicit power to extract an excessive price. . . . Each time a plaintiff is injured by an act of the defendants a cause of action accrues to him to recover the damages caused by that act.”39 Thus, "each time MDL was allegedly forced to pay a supra-competitive price as a result of Roche's and Applera's anticompetitive conduct, a separate injury accrued."40 Judge Kennedy allowed MDL to assert a claim for each of its purchases accruing up to four years before MDL filed its complaint. ${ }^{41}$

\section{i. $\quad$ Settlement}

Following the ruling on the motion to dismiss, MDL amended the complaint, redefining the class to include anyone that purchased Taq products from the defendants from September 23, 2000 until the present. ${ }^{42}$ In 2008, the Defendants filed motions for summary judgment. ${ }^{43}$ However, the court never ruled on those motions as the parties entered into a Settlement Agreement on September 26, 2008. ${ }^{44}$ The Defendants agreed to pay $\$ 33$ million to a class of direct purchasers, of which one third would be paid to the plaintiffs' attorneys. ${ }^{45}$ The settlement also provided that the plaintiffs' attorneys would receive in addition the reasonable costs and expenses incurred during litigation, and that MDL would receive an incentive payment of $\$ 40,000$ for being the named party to the litigation. ${ }^{46}$ Judge Kennedy approved the agreement on December 19, 2008, including the award of \$11 million in attorney’s fees and over \$3 million in reimbursement for costs and expenses incurred by the plaintiffs' attorneys. ${ }^{47}$

\footnotetext{
${ }^{35}$ Molecular Diagnostics Labs., 402 F. Supp. 2d at 282.

${ }^{36}$ Id. at 285 .

${ }^{37} \mathrm{Id}$.

${ }^{38}$ Id. at $285-86$

${ }^{39}$ Id. at 286.

${ }^{40} I d$.

${ }^{41} \mathrm{Id}$.

${ }^{42}$ Revised First Amended Compl. If 8 June 29, 2006.

${ }^{43}$ See Applied Biosystems Inc.'s Memorandum of Points and Authorities in Support of Its Motion for Summary Judgment, No. 104-CV-01649, 2008 WL 5667603, July 25, 2008; see also Roche Defendants' Motion for Summary Judgment On Sham Enforcement and Walker Process Fraud, No. 104-CV-01649, 2008 WL 5667602, July 25, 2008. ${ }^{44}$ Settlement Agreement between Molecular Diagnostics Labs. \& Hoffmann-La Roche Inc. et al., No. 1:04CV01649 (HHK) Sept. 6, 2008 available at http://www.completeclaimsolutions.com/taq/.

${ }^{45}$ Id. ๆๆ 6, 12.

${ }^{46} \mathrm{Id}$. at 912.

${ }^{47}$ Final Order Approving Settlement and Entering Judgment, No. 1:04CV01649 (HHK), Dec. 19, 2008.
} 


\section{Methionine Antitrust Litigation ${ }^{1}$}

This case is notable because: (1) the direct purchaser class plaintiffs received a total in damages of $\$ 107$ million in cash; (2) the plaintiffs' attorneys were awarded $\$ 24,000,000$ in fees and $\$ 977,288$ in costs (overall 23.3\%).

\section{A. Procedural Background}

Methionine is an amino acid that is used principally as an animal feed additive. During the relevant period (1985-2000), the defendants were alleged to be the largest suppliers and producers of methionine in the world, controlling around 85 percent of the global market for methionine and 100 percent of the methionine sold in the United States.

On July 19, 1999, plaintiff A.L. Gilbert filed the first methionine antitrust class action in the Northern District of California, San Francisco Division, Case No. 993491 (PJH). It named Rhone-Poulenc S.A., Rhone-Poulenc AG Company, Inc., Degussa-Hüls AG, Degussa-Hüls Corp., Mitsui \& Co., Ltd., Nippon Soda Company, Ltd., and Novus International, Inc. as defendants. $^{2}$ Other related civil actions were also filed in various federal district courts. ${ }^{3}$ The plaintiffs included A.L. Gilbert, a California corp., Feedstuffs Processing Co., a California corp., AAA Egg Farm, a partnership in Lakeview, California, Smithfield Foods, Inc., a Virginia corp., and others.

On December 8, 1999, the Judicial Panel on Multidistrict Litigation (“JPML”) ordered pursuant to 28 U.S.C. $\S 1407$ that methionine related actions be transferred to the Northern District of California for coordinated or consolidated pretrial proceedings. The JPML, after initially assigning MDL Docket No. 1311 to Judge Samuel Conti, reassigned the case at the request of Chief Judge Marilyn Hall Patel to Judge Charles R. Breyer. An MDL docket was then opened by the United States District Court, Northern District of California on January 10, 2000. A consolidated direct purchaser class action complaint for violations of the Sherman Act was then filed on April 10, 2000. Tag- along cases such as West Bend Elevator, Inc. v. RhonePoulenc, S.A., et. al. were also subsequently transferred by the JPML to the United States District Court, Northern District of California, for coordinated or consolidated pretrial proceedings. Other associated cases were filed directly in the United States District Court, Northern District of California's MDL 1311 docket. $^{4}$

\footnotetext{
${ }^{1}$ United States District Court, Northern District of California (MDL) M:00-cv-01311-CRB

${ }^{2}$ See Memorandum of Points and Authorities in Support of A.L. Gilbert's Notice of Motion and Motion for Transfer and Coordination or Consolidation Under 28 U.S.C. § 1407, p.2 (Aug. 30, 1999), attached as Ex. 2.

${ }^{3}$ Id. at 3-5.

${ }^{4}$ Smithfield Foods Inc, et al v. Rhone-Poulenc S.A., et al, 3:00-cv-00548-CRB

Cox Veterinary Labs v. Rhone-Poulenc S.A., et al, 3:00-cv-00667-CRB

Animal Science Products, et al v. Rhone-Poulenc S.A., 3:00-cv-00873-CRB

Central Connecticut v. Rhone-Poulenc S.A., et al, 3:00-cv-00874-CRB

Tyson Foods, Inc., et al v. Degussa-Huls Corp., et al, 3:01-cv-00944-CRB

A.L. Gilbert v. Rhone-Poulenc S.A., et al, 3:99-cv-03491-CRB

Feedstuffs Proc. v. Novus International, et al, 3:99-cv-03492-CRB

AAA Egg Farm v. Rhone-Poulenc S.A., et al, 3:99-cv-03999-CRB

Mid South Feed v. Rhone-Poulenc S.A., et al, 3:99-cv-04274-CRB

Coast Grain Company v. Rhone-Poulenc S.A., et al, 3:99-cv-04392-CRB

Vitagold Brands v. Novus International, et al, 3:99-cv-04553-CRB

Iowa Select Farms LP v. Rhone-Poulenc S.A., et al, 3:99-cv-04802-CRB

O.H. Kruse v. Rhone-Poulenc, Inc., et al, 3:99-cv-04998-CRB
} 
In re Methionine arises out of an alleged conspiracy from January 1, 1985 to 2000 between defendants Rhone-Poulenc SA (n/k/a Aventis SA), Degussa-Hüls AG (n/k/a Degussa AG), Mitsui \& Co., Ltd (and related subsidiaries, such as Mitsui \& Co. (U.S.A.), Inc.), Novus International, Inc. and Nippon Soda Co, Ltd.12 to (1) artificially fix the price of methionine, and (2) allocate markets and customers for the sale of methionine. ${ }^{5}$

Methionine cases before the District Court for the Northern District of California included a consolidated nation-wide class action on behalf of direct purchasers, a class action brought by indirect purchasers, and actions by individual opt-out direct purchasers.

The direct purchaser class action plaintiffs claimed the illegal conspiracy by defendants had the effect of fixing, raising or maintaining an artificially high price for methionine. The case was brought pursuant to Sections 4 and 16 of the Clayton Act, 15 U.S.C. § 12, et seq., to obtain injunctive relief, and to recover costs (including attorney's fees) and treble damages for injuries sustained by the class, as a result of defendants' alleged violations of Section 1 of the Sherman Act, 15 U.S.C. $\S 1$, et seq. The direct purchaser class was defined as "[a]ll persons or entities (excluding governmental entities, defendants, defendants' parents, subsidiaries and affiliates, and other producers of methionine and their subsidiaries and affiliates) who purchased methionine in the United States directly from any of the defendants (including all persons or entities outside of the United States who purchased methionine directly from any of the defendants which products were delivered from or to a plant or facility located in the United States at any time during the period January 1, 1985 through December 21, 2000.” All lawsuits related to these price fixing allegations were consolidated under 28 U.S.C. § 1407 as multi- district litigation and transferred to the District Court for the Northern District of California.

\section{i. $\quad$ Settlements}

Each of the methionine cases in MDL 1311 sought to recover damages for overcharges resulting from the price-fixing. The Court certified the direct purchaser class action for litigation purposes, and in August 2002, approved a \$107 million dollar settlement, which it referenced in a published opinion. The terms of the direct purchaser class action settlement, which was negotiated on March 5, 2002, were summarized and outlined in attachments to the court's order preliminarily approving settlement, filed May 10, 2002. In exchange the direct purchaser class action was dismissed with prejudice.

The plan of allocation provided for the distribution of settlement funds after payment of expenses on a pro rata basis among class members based on the dollar amount each class

Jerome Foods, Inc. v. Rhone-Poulenc S.A., et al, 3:99-cv-05362-CRB

Int'l Nutrition v. Rhone-Poulenc S.A., et al, 3:99-cv-05363-CRB

Holden Mills Company v. Rhone-Poulenc S.A., et al, 3:99-cv-05397-CRB

Buckeye Egg Farm LP v. Rhone Poulenc S.A., et al, 3:99-cv-05454-CRB

Austin v. Apfel, 3:00-cv-00944-SC

West Bend Elevator v. Rhone-Poulenc SA, et al, 3:00-cv-03961-CRB

${ }^{5}$ In 1999, Rhone-Poulenc SA, a French chemical and pharmaceutical company merged with Hoechst AG to form Aventis SA. Other Rhone-Poulenc SA entities sued in this litigation include Rhone-Poulenc Animal Nutrition SA (n/k/a Aventis Animal Nutrition SA) and Rhone- Poulenc Animal Nutrition Inc. (n/k/a Aventis Animal Nutrition Inc.) (Collectively, "Rhone- Poulenc”). Degussa-Hüls is a specialty chemicals company (now known as Degussa AG) with its principal place of business in Germany. Mitsui \& Co., Ltd. is a Japanese corporation. Novus International, Inc. is a privately held corporation duly formed and existing under the laws of Delaware. Novus is owned by Defendant Mitsui \& Co., Ltd. (65 percent), and Defendant Nippon Soda Co., Ltd. (35 percent). Nippon Soda is a Japanese corporation. 
member paid to defendants for its direct purchases of methionine during the period January 1 , 1986 through December 31, 1998. Purchases had to have been made directly from a defendant to qualify. It is unknown how much money total, was recovered by each business-plaintiff. Attorney's fees were capped in the settlement in an amount not to exceed $29 \%$ of the settlement fund, reimbursement of expenses, and interest thereon. The Court ultimately awarded class counsel with reimbursement of expenses incurred in the aggregate amount of $\$ 977,288.61$ and $\$ 24,000,000.00$ in fees, overall $23.3 \%$ of the settlement.

The direct purchaser opt-out actions subsequently settled in late 2002 and early 2003. Unlike the direct purchaser class action, the opt-out purchaser settlements were not subject to Court approval and remain confidential to this day. Finally, in 2003, the Court decertified the class in the remaining indirect purchaser class action - for all intents and purposes, ending the In re Methionine MDL litigation.

In re Methionine was filed before Twombly and Iqbal, and the Class Action Fairness Act. There is no evidence that the methionine antitrust cases lacked merit or were subject to criticism. While it was a substantial multi-district price-fixing matter, it did not establish any lasting or important legal precedent. It also appears that both the media and legal scholars did not give it any significant attention. There was no related government action by the U.S. Department of Justice or the FTC. The case was overseen by Judge Charles R. Breyer (nominated by William J. Clinton, July 24, 1997, confirmed by the U.S. Senate, Nov. 8, 1997.) 


\section{MSG (Monosodium Glutamate Antitrust Litigation) ${ }^{1}$}

This case is notable because: (1) the class of direct purchaser plaintiffs received a total in damages of $\$ 123.4$ million plus interest; (2) damages of $\$ 122$ million were from foreign companies; (3) the plaintiffs' attorneys were awarded $\$ 24.42$ million with interest (19\%); (4) the plaintiffs' attorneys were reimbursed almost $\$ 2$ million for costs and expenses; and (5) the court awarded \$174,000 in additional incentive awards ${ }^{2}$.

\section{A. Factual Background}

Monosodium glutamate ("MSG") is the nucleotide most commonly used as a flavor enhancer. Nucleotides refers to all nucleotide-based flavor enhancers, including disodium inosinate (sometimes called "DSI" or "IMP"), disodium guanylate (sometimes called "DSG" or "GMP") and combinations thereof (sometimes called "I+G").

\section{B. Procedural Background}

\section{i. Preliminary Proceedings}

Several complaints were filed in 1999 and early 2000 against Ajinomoto Co., Inc. (“Ajinomoto”), Archer Daniels Midland Company (“ADM”), Daesang America, Inc., Takeda Chemical Industries, Ltd. (“Takeda”), CJ Corp., formerly known as Cheil Jedang Corporation and CJ America,Inc., Miwon Company Ltd., Kyowa Hakko Kogyo Co., Ltd. (“Kyowa”) which will collectively be referred to as the Defendants ${ }^{3}$ under 15 U.S.C. $\S 1$. The plaintiffs ${ }^{4}$ alleged that certain manufacturers of MSG and/or nucleotides unlawfully conspired to fix prices and allocate markets for nucleotides. Damages were sought on behalf of all people who purchased MSG and/or nucleotides or products containing such between the years 1990 and 1999. On March 3, 2000, the six member cases were consolidated ${ }^{5}$ and transferred to the District of Minnesota.

On Sept 14th, 2000 the Court granted defendants’ partial motion to dismiss without prejudice. The court granted the Plaintiffs leave to amend the Complaint to replead the fraudulent concealment claim. ${ }^{6}$ The following year the court certified a class of direct purchasers. $^{7}$

\footnotetext{
${ }^{1}$ (MDL No. 1328 (D. Minn.). Judge: Paul A. Magnuson. Jurisdiction: U.S. District Court for the District of Minnesota. Filed: On March 3, 2000 the Judicial Panel on Multidistrict Litigation transferred the action to that U.S. Dist. Ct.

${ }^{2}$ In a order dated 11/18/03 Judge Magnuson ordered the following: The class representatives, Diversified Foods \& Seasonings, Inc., M. Phil Yen, Inc., Felbro Food Products, Inc and Y. Hata \& Co. Ltrd., are each awarded \$25,000 to be paid from the settlement fund. The remaining named plaintiffs, Premiium Ingredients, Ltd., Chicago Ingredients, Inc., Heller Seasonings \& Ingredients, Inc., First Spice Mixing Co., Inc., and Thorp, Inc., ar each awarded $\$ 15,000$ to be paid from the settlement funds.

${ }^{3}$ Id.

${ }^{4}$ Diversified Foods and Seasonings, Inc., M. Phil Yen, Inc., Felbro Food Products, Inc, and Y. Hata \& Co., Ltd. were appointed as class representatives. In re Monosodium Glutamate, 205 F.R.D. 229, 235 (D. Minn. 2001).

${ }^{5}$ In re Monosodium Glutamate Antitrust Litig., 2000 U.S. Dist. LEXIS 2451 (J.P.M.L. Mar. 2, 2000).

${ }^{6}$ In re Monosodium Glutamate Antitrust Litig., 2000 U.S. Dist. LEXIS 22521 (D. Minn. Sept. 13, 2000).

${ }^{7}$ In re Monosodium Glutamate, 205 F.R.D. 229, 235 (D. Minn. 2001).
} 


\section{ii. Settlement}

\section{a. Kyowa, Takeda, ADM, and Ajinomoto Defendants}

Plaintiffs entered into Settlement Agreements with Defendants Kyowa Hakko Kogyo Co., Ltd. ("Kyowa”), Takeda Chemical Industries, Ltd. (“Takeda”), Archer Daniels Midland Company (“ADM”), and Ajinomoto Co., Inc. (“Ajinomoto”), with Orders for Final Judgment entered on January 25, 2002 for Defendant Kyowa, ${ }^{8}$ August 15, 2002 for Defendant Takeda November 7, 2002 for Defendant ADM $^{10}$, and November 7, 2002 for Defendant Ajinomoto. ${ }^{11}$

Defendant ADM agreed to pay \$ 1.25 million $^{12}$ The settlement with Ajinomoto secured a recovery of $\$ 58$ million. Defendant Takeda agreed to pay $\$ 22$ million. $^{13}$

On January 9, 2003, the Court issued its Order Approving Plan of Distribution of Settlement Funds with regard to the settlements with Defendants Kyowa, Takeda, Ajinomoto and ADM.

\section{b. CJ Corp Defendants}

As a result of the settlements, all defendants but two settled the claims against them. The two remaining defendants, CJ Corp. moved for summary judgment. The Court denied Defendants' various motions for partial summary judgment and Defendants' Motions to Strike were denied. ${ }^{14}$

Plaintiffs subsequently entered into a Settlement Agreement with defendant CJ Corp., formerly known as Cheil Jedang Corporation and CJ America, Inc. on July 15, $2003^{15}$. This settlement secured a recovery of $\$ 42$ million. ${ }^{16}$ On March 5, 2004, the Court issued its Order re: Distribution of Class Settlement Fund ${ }^{17}$ dated March 5, 2004. In that Order, the Court directed Plaintiffs' Counsel to adhere to the plan of distribution and allocation previously approved by the Court in its January 9, 2003 order and in its September 10, 2003 order for the distribution of the combined settlement funds. Ultimately the settlements procured in the direct purchaser class action totaled \$ 123.4 million. The direct purchaser class action settled completely in 2003. On February 6, 2003 the court awarded attorney's fees to plaintiff's counsel in the amount of \$24.4 million. ${ }^{18}$

\footnotetext{
${ }^{8}$ Kyowa Order for Final Judgment 01-25-02

${ }^{9}$ Takeda Order for Final Judgment 11-07-02

${ }^{10}$ ADA Order for Final Judgment 11-07-02

${ }^{11}$ Ajinomoto Order for Final Judgment 11-07-02

${ }^{12}$ ADM Settlement Agreement 07-30-02

${ }^{13}$ Takeda Chemical MOL Final Approval Settlement (08/08/02)

14 “Defendants' Motion for Partial Summary Judgment Barring Pre-1995 Damages (Clerk Doc. No. 294) is denied; Defendant CJ America's Motion for Partial Summary Judgment on Claims Related to Nucleotides (Clerk Doc. No. 317) is denied; Defendants' Motion for Partial Summary Judgment Barring Post-1997 Damages as to Nucleotides and Barring Damages as to MSG (Clerk Doc. No. 319) is denied; and Defendants' Motions to Strike (Clerk Doc. Nos. 301, 340, 342) are denied.

${ }^{15}$ CJ Corp Settlement Agreement 07-15-03

${ }^{16}$ Cheil MOL Final Approved Settlement (09-02-03)

${ }^{17}$ Order re: Distribution of Class Settlement Fund (03-05-04) Doc. 460

${ }^{18}$ After careful consideration of the materials submitted, the Court concludes that an award of $30 \%$ of the settlement fund is reasonable in this matter. Thus, the Court finds that Plaintiffs' counsel are entitled to an award of \$ 24,420,000, plus the costs claimed in the Application.(In re Monosodium Glutamate Antitrust Litig., 2003 U.S. Dist. LEXIS 1970 (D. Minn. Feb. 6, 2003).
} 


\section{iii. Related Actions}

In Four B. Corp. v. Archer Daniels Midland Co,. ${ }^{19}$ the court granted the two defendants, ADM. and Takeda, motion to dismiss because the plaintiff's complaint was untimely. The plaintiffs' in this case were not direct purchasers of the products at issue, but rather grocery store chains that alleged that the conspiracy to fix prices injured them.

In Conopco, Inc. v. Daesang Japan, Inc., et al., a direct purchaser of the products at issue timely opted out of the umbrella MDL class action. In a motion to dismiss the Defendants asserted several theories, which the court rejected. ${ }^{20}$ Ultimately the parties entered into a settlement agreement on February 1, 2005 that is filed under seal.

\section{iv. Judge}

Judge Paul A. Magnuson of the U.S. District Court for the District of Minnesota presided over the litigation. He was nominated by President Ronald Reagan.

${ }^{19}$ Four B. Corp. v. Archer Daniels Midland, Memorandum and Order dated 11/3/03.

${ }^{20}$ In re Monosodium Glutamate Antitrust Litig., 2003 U.S. Dist. LEXIS 23237 (D. Minn. 2003). Specifically,

defendants argued that "(1) plaintiff failed to plead fraudulent concealment with the particularity required by Fed. R. Civ. P. 9(b), (2) plaintiff had no standing to bring antitrust claims because it failed to allege it directly purchased the product at issue from any defendant, and (3) plaintiff's attempts to bring claims on behalf of "ratifying entities" failed under Fed. R. Civ. P. 17(a)'s real-party-in-interest requirement." The court found that the defendants' first argument failed because plaintiff set out 11 types of affirmative acts defendants allegedly took to conceal an alleged conspiracy; some of the acts were merely acts taken in furtherance of the conspiracy, but others, such as providing plaintiff with false or misleading explanations for pricing of the product constituted affirmative acts of concealment for the purposes of pleading a claim of fraudulent concealment. The second argument failed because plaintiff sufficiently pled that it made purchases. The final argument failed because plaintiff filed with the court copies of a number of ratifications of the various entities, shortly after the hearing on the instant motion. 


\section{Mylan (In re Lorazepam \& Clorazepate Antitrust Litigation) ${ }^{\mathbf{1}}$}

This case is notable because: (1) the government action received a settlement of $\$ 100$ million, (\$72 million went to states for claims by individual consumers and \$28 million to state agencies), as well as an additional $\$ 12$ million in attorneys' fees and costs; ${ }^{2}$ (2) the plaintiffs in the indirect purchaser class received a total settlement of \$35 million, \$6 million of which went to attorneys' fees and costs; ${ }^{3}$ (3) the plaintiffs in the direct purchaser class received a settlement of \$35 million minus 30\% attorneys' fees and costs of approximately $\$ 1$ million; $^{4}$ (4) an unfinalized judgment of $\$ 73$ million for six insurance companies that opted out of the indirect purchaser settlement is still pending a decision in district court after remand ${ }^{5}$; (5) it was the largest monetary FTC settlement at that time.

\section{A. Factual Background}

Mylan Laboratories ("Mylan") is one of the largest pharmaceutical manufacturers in the world. Mylan manufactures Lorazepam and Clorazepate, generic versions of widely used antianxiety drugs. Gyma, Profarmaco, and Cambrex were involved in supplying Active Pharmaceutical Ingredients (APIs) to drug manufacturers, including Mylan. ${ }^{6}$

To obtain FDA approval, a generic manufacturer such as Mylan must file an Abbreviated New Drug Application (ANDA) to establish that its generic version is equivalent to the branded drug. ANDA approval takes an average of 18 months. To make the drug, the manufacturer purchases the APIs from a supplier. An API supplier must file a Drug Master File (DMFs) with the FDA in order to sell APIs in the United States. An ANDA must specifically reference the DMF of only one API supplier. Changing API suppliers requires FDA approval of an ANDA supplement with test results using the new API. The process takes another 18 months on average. Mylan's ANDA referenced Defendant Gyma's DMF. Gyma is a distributor of APIs manufactured by Cambrex and Profarmaco. Defendant SST, like Gyma, is an API distributor; however, it sold only to Mylan's competitors, not Mylan itself. ${ }^{7}$

Mylan allegedly entered into a 10 year exclusive contract with Profarmaco and Gyma under which these firms would license exclusively to Mylan. It offered to pay a certain percentage of gross profits. Mylan would have complete control over all of Cambrex and Profarmaco's APIs for the two drugs. Its competitors would not have access to any APIs for the two drugs from Profarmaco or Gyma. Mylan also attempted to obtain an exclusive license deal with Defendant SST, despite the fact that it had no ANDA authorization to use SST's APIs for its drugs. Plaintiffs allege that SST did not agree to the exclusive licensing deal, but that SST did agree to raise prices of its APIs to match those of Gyma. ${ }^{8}$

\footnotetext{
${ }^{1} 205$ F.R.D 369 (D.D.C. Feb. 1, 2002)

${ }^{2} \$ 6.8$ million in attorneys' fees and leadership awards were paid to the states' attorneys and their staff. \$1.3 million were paid to the states' attorneys offices for costs and expenses. $\$ 4$ million in fees and costs were paid to private plaintiffs for their assistance during discovery and settlement on the states' case. Id. at 383-387.

${ }^{3}$ See In re Lorazepam, Id. at 399.

${ }^{4}$ The fee awarded was $30 \%$ of the settlement funds, including interest, which was $\$ 10,698,115.69$ as of April 30 , 2003. The court awarded $\$ 1,075,076.81$ in costs, subtracted from the settlement fund. In re Lorazepam, $2003 \mathrm{WL}$ 22037741, at *3 (D.D.C. June 16, 2003) (order approving settlement with direct purchaser class).

${ }^{5}$ In re Lorazepam, 631 F.3d 537 (D.C. January 18, 2011).

${ }_{7}^{6}$ In re Lorazepam, 202 F.R.D. 12, 16 (D.D.C. July 2, 2001) (approving class certification for direct purchasers).

${ }^{7}$ Id.

${ }^{8}$ Id.
} 
On January 12, 1998, Mylan raised the price of Lorazepam 1,900 to 3,900 percent and Clorazepate 1,900 to over 6,500 percent, depending on bottle size and strength. Plaintiffs allege that there was no significant increase in costs to justify this price raise. Shortly thereafter, SST raised the price of its APIs approximately 19,000 percent. Mylan's competitor, Geneva pharmaceuticals, a buyer from SST, raised the price of its tablets to approximately the same as Mylan's. ${ }^{9}$

\section{B. Procedural Background}

On December 21, 1998 the FTC filed suit pursuant to the FTC act, 15 U.S.C. §§ 45 \& 53 against defendants Mylan, Cambrex, Profarmaco, and Gyma seeking injunctive and equitable relief, as well as $\$ 120$ million in disgorged profits, plus interest. The amended complaint alleged the defendants had engaged in unfair methods of competition. On December 22, 1998, the attorney generals of 10 states filed suit against the same defendants plus SST as parens patriae for individual consumers and on behalf of state agencies seeking equitable relief and treble damages for violations of section 1 and 2 of the Sherman act and the Clayton act. They were eventually joined by all 50 states. ${ }^{10}$ Several class action suits by indirect and direct purchaser Plaintiffs were filed shortly thereafter. ${ }^{11}$

On July 7, 1999, the courts denied in part and granted in part motions to dismiss the FTC and states' complaint. The court rejected Defendants' argument that the FTC cannot seek monetary relief and a permanent injunction in an antitrust case. However, the court dismissed those portions of the states' complaint pursuant to the Sherman act, limiting the case to section 4 of the Clayton act. ${ }^{12}$

On July 2, 2001, the court denied the defendants' motion to dismiss a class action suit by direct purchasers. ${ }^{13}$ Defendants argued that, as an issue of first impression in the D.C. Circuit, the Plaintiffs had no standing to recover treble damages since the FTC disgorgement action already represented a potential recovery by direct purchasers. The court denied defendants' motion, holding Congress commonly creates different causes of action through different statutes relating to the same conduct and that if necessary the court could utilize apportionments to avoid duplicate recovery at a later stage in the lawsuit. In the same order, the court granted class certification in the direct purchaser action, which included hospitals, drug wholesalers, and group

\footnotetext{
${ }^{9}$ Id. at 17.

${ }^{10}$ In 2000, settlement negotiations began between the FTC, the states, and Mylan and its suppliers. As part of the settlement negotiations, the participating states agreed to attempt to bring in the remaining states. They were successful. On February 1, 2001, all fifty states and D.C. filed a joint third party amended complaint. In re Lorazepam, 205 F.R.D. at 373 (order certifying class of direct purchasers) (summarizing the procedural history of the case).

${ }^{11}$ In re Lorazepam, 205 F.R.D 369, 373 (D.D.C. Feb. 1, 2002).

${ }^{12}$ F.T.C. v. Mylan Laboratories, Inc., 62 F.Supp.2d 25 (D.D.C. July 7, 1999).

${ }^{13}$ In re Lorazepam, 202 F.R.D. 12 (D.D.C. 2001) (approving class certification a
} 
purchaser organizations. ${ }^{14}$ Defendants sought an interlocutory appeal of the orders, which was denied. ${ }^{15}$

\section{i. Settlement}

\section{a. Government Plaintiffs and Indirect Purchasers}

On February 1, 2002, the court approved settlement of the following lawsuits: 1) the FTC's suit; 2) the Plaintiff states' suit 3) two suits involving indirect purchaser Plaintiffs; 4) and a global settlement involving defendant SST.

The FTC and the states settled with all defendants for $\$ 100$ million $^{16}$ plus $\$ 12$ million in attorneys' fees and costs. ${ }^{17}$

The two lawsuits involving indirect purchaser Plaintiffs settled for a combined total of $\$ 35$ million that same day, including \$6 million in attorney’s fees and costs. ${ }^{18}$ Several class members objected to the indirect purchaser settlement as too low, and six of the class members opted out. All four opt-outs were Blue Cross Blue Shield organizations. ${ }^{19}$ The Blues' case continues to the present. It resulted in a jury verdict, which was subsequently trebled to $\$ 73$ million. That award was remanded to address jurisdictional issues, and is awaiting an order by the District Court. That litigation is not final and the award is therefore not included in this study. ${ }^{20}$

Defendant SST settled with all Plaintiffs that same day for a total of \$2 million, including attorney's fees and costs. ${ }^{21}$

\section{b. Direct Purchasers}

On June 16, 2003, the direct purchaser suit settled with all defendants for \$35 million. Attorneys' fees of $30 \%$, plus $\$ 1,075,076.81$ in costs were approved. ${ }^{22}$

\footnotetext{
${ }^{14}$ The court rejected Defendants' arguments that direct purchasers were too difficult to distinguish from indirect purchasers, warning that Defendants' arguments came "dangerously close to making the senseless point that no one may be sued for antitrust injury in the pharmaceuticals industry because it is too difficult to weed out the indirect purchasers." In re Lorazepam, 202 F.R.D. at 23 (approving class certification and denying motion to dismiss).

${ }^{15}$ It was the first time in the D.C. Circuit when the question of whether to grant an interlocutory appeal of class certification. The D.C. Circuit held that Defendant's standing arguments did not warrant interlocutory review. In re Lorazepam, 289 F.3d 98 (May 14, 2002).

${ }^{16}$ From the $\$ 100$ million, $\$ 71,782,017$ went to satisfy the consumer claims in the States' lawsuit and \$28,217,983 went to satisfy the States' agency claims. This was the largest monetary settlement in FTC history at the time. FTC Reaches Record Financial Settlement to Settle Charges of Price-fixing in Generic Drug Market, FEDERAL TRADE Commission (November 29, 2000), http://www.ftc.gov/opa/2000/11/mylanfin.shtm.

17 \$6.8 million in attorney’s fees and leadership awards were paid to the states' attorneys and their staff. \$1.3 million were paid to the states' attorneys for costs and expenses. $\$ 4$ million in fees and costs were paid to private plaintiffs for their assistance to the states during discovery and settlement. Id. at 383-387.

${ }^{18}$ See In re Lorazepam, 205 F.R.D. at 399.

${ }^{19}$ See In re Lorazepam, Id.. at 378 (order approving settlement).

${ }^{20}$ In re Lorazepam, 631 F.3d 537 (D.C. Cir. 2011).

${ }^{21}$ In re: Lorazepam, 205 F.R.D. at 376, n.11 and accompanying text.

${ }^{22}$ As of April 30, 2002, 30\% of the $\$ 35$ million, including the accrued interest, was $\$ 10,698,115.69$. In re Lorazepam, 2003 WL 22037741, at*3 (D.D.C. June 16, 2003) (order approving settlement with direct purchaser class).
} 


\section{ii. $\quad$ Related Actions}

In 2007, Mylan settled a legal malpractice claim with its former attorneys related to their handling of some of these actions for an undisclosed amount. ${ }^{23}$

\section{iii. Judge}

Judge Thomas F. Hogan presided over each of the above-discussed actions. Judge Hogan was nominated by Ronald Reagan. ${ }^{24}$

\footnotetext{
${ }^{23}$ Mylan Pharmaceuticals, Inc. v. Clifford Chance US LLP, Civ Action No. 1:03 CV 16, Document \#593 (N.D.W.Va. January 5, 2007) (stipulation of dismissal).

${ }^{24}$ Hogan, Thomas Francis, Biographical Directory of Federal Judges, Federal Judicial CenTER, http://www.fjc.gov/servlet/nGetInfo?jid=1068\&cid=999\&ctype=na\&instate=na (last accessed, March 18, 2011).
} 


\section{Novell v. Microsoft ${ }^{1}$}

This case is noteworthy because: (1) the plaintiffs received a total settlement of \$536 million cash, \$88 million of which were attorney's fees (16.4\%); (2) it was a follow on to the European Commission's investigation and judgment against Microsoft for leveraging its dominant position in the PC operating system market into the group server operating system market by refusing to supply competitors with interoperability information.

\section{A. Procedural Background}

On November 8, 2004, Novell and Microsoft settled a potential lawsuit involving Novell's Netware software for $\$ 536$ million cash (hereafter, the Netware settlement). ${ }^{2}$ The Netware settlement is confidential and no law suit was filed, so it is impossible to know exactly what positions Novell and Microsoft took in regards to the settlement. However, most of Novell's potential evidence was probably provided by the European Commission's 1998-2007 case against Microsoft (hereafter, the "EU case”). ${ }^{3}$

The specific antitrust harm at issue in the Netware settlement is unknown, but probably constituted a violation of Section 2 of the Sherman Act (and thus presumably a rule of reason case). Into the early 90s, Novell had a $70 \%$ market share over the group server operating system market with its Netware software product. Microsoft's Windows NT server and other products, however, started to make headway and quickly gained the dominant market share, which Microsoft continues to enjoy to date. ${ }^{4}$ Opinions about the failure of Netware are numerous. Those who side with Microsoft assert strategic mistakes on the part of Novell, such as its late adoption of certain features like the now omnipresent TCP/IP protocol and a more modern graphical user interface. They also cite a failure or inability to market to corporate executives rather than technical end-users. ${ }^{5}$ Those who side with Novell cite Microsoft's strategy of undercutting confidence in Novell products, ${ }^{6}$ and, most relevant to the E.U. case, cite the fact that Microsoft

\footnotetext{
${ }^{1}$ Complaint not filed.

${ }^{2}$ See Novell, Novell Settles One Antitrust Claim with Microsoft for \$536 Million, Plans to File Suit on Second Claim (Nov. 8, 2004), http://www.novell.com/news/press/archive/2004/11/pr04076.html; MiCROSOFT NEWS CENTER, Novell and Microsoft Reach Settlement on Antitrust Claims: Novell Releases Claims for Netware and Agrees to Withdraw from European Commission Case (Nov. 8, 2004), http://www.microsoft.com/presspass/press/2004/nov04/11-08NovellPR.mspx.

${ }^{3}$ See Alison Frankel, Risky Business, AMERICAN LAWYER, Jan. 2005, at 84.

${ }^{4}$ See, e.g., Deni Connor, Novell NetWare vs. Microsoft networking, NeTwORKWorLD, (Oct. 26, 2007)

http://www.networkworld.com/news/2007/102607-arguments-netware-microsoft.html?nwwpkg=50arguments.

${ }^{5}$ See id.

6 "One of the most recent alleged examples of such behavior occurred in 1999. For a short period in that year, Microsoft informed developers that it no longer planned to provide support for the popular Novell Directory Service (NDS). This directory service is a popular networking tool employed by users of Microsoft's Windows NT operating system. Although Microsoft did not ultimately remove support, its actions may have successfully instilled concern in IT managers that NDS' future compatibility with Windows was in jeopardy." Andrew V. Leventis \& Michelle R. Appelrouth Are Section 2 Claims More Than Mere Apparitions?, 15 SPG ANTITRUST 82 (2001). See also NovELL eDirecotry and Netware vs. Active Directory and Windows, (posted Oct 13, 2004),

http://www.novell.com/coolsolutions/feature/5992.html ("Quite often, system admins will complain that IT or management at their companies are putting undue pressure on them to switch from Novell to Microsoft products, or
} 
Windows did not provide certain Windows information and specifications (called by the EU case, "interoperability information"7) to competitors, so that a non-Microsoft created group server operating system such as Novell Netware would be slowed by inefficient processes. $^{8}$

\section{i. $\quad$ Foreign Legal Action}

The EU case began in 1998 when Sun Microsystems (Sun) filed an application to the European Commission for proceedings against Microsoft for not providing interoperability information about its extremely dominant PC operating systems to producers of group server operating systems, such as Novell's Netware. The Commission combined the Sun complaint with its own investigation concerning the bundling of Windows Media Player. In 2003, the Commission engaged in a "market enquiry," receiving responses to requests for information from over 100 companies on the issue of interoperability, and admitting many companies as interested third parties, including Novell. $^{9} \quad$ On April 21, 2004, the Commission ruled against Microsoft in both investigations, ${ }^{10}$ providing an extensive market analysis of not only the work group operating system market, but work operating system tasks. ${ }^{11}$ Microsoft was fined EUR 497,196,304; was ordered to make non-bundled versions of Windows and Windows Media Player available on the market within 90 days; and was ordered to provide interoperability information within 120 days, subject to compliance oversight by the Commission. $^{12}$ Novell withdrew from involvement in the E.U. case on November 8, 2004 under the terms of the settlement agreement. ${ }^{13}$ Microsoft asked for an annulment of the decision, which was denied on September 17, 2007 by the Court of First Instance. ${ }^{14}$

The ruling in the EU case highlights essential tensions between antitrust law and intellectual property law in a high technology market. ${ }^{15}$ The U.S. approach in its public

generally spreading FUD (fear, uncertainty, and doubt) about NetWare and eDirectory. So how about some comeback material?")

7 "[T]he term interoperability Information means the complete and accurate

specifications for all the Protocols implemented in Windows Work Group Server

Operating Systems and that are used by Windows Work Group Servers to deliver file

and print services and group and user administration services, including the Windows

Domain Controller services, Active Directory services and Group Policy services, to

Windows Work Group Networks." Commission Decision COMP/C-3/37.792 Microsoft, C(2004)900, at Article 1, available at http://ec.europa.eu/comm/competition/antitrust/cases/decisions/37792/en.pdf.

${ }^{8}$ See Commission Decision COMP/C-3/37.792 Microsoft, C(2004)900, at note 786 and accompanying text, available at http://ec.europa.eu/comm/competition/antitrust/cases/decisions/37792/en.pdf.

${ }^{9}$ See id at recital 3-13.

${ }^{10}$ Specifically, Microsoft's refusal to provide interoperability information and bundling of Windows with Windows Media Player infringed Article 82 of the Treaty establishing the European Community and Article 54 of the EEC

Treaty. See id. at Article 2.

${ }^{11}$ See Id. at recital 500.

${ }^{12}$ See id. at Articles 3, 5, 6.

${ }^{13}$ See supra note 1 , NOVELL settlement announcement.

${ }^{14}$ Decision available at http://eur-lex.europa.eu/LexUriServ/LexUriServ.do?uri=CELEX:62004A0201:EN:NOT.

${ }^{15}$ See, e.g., Clayton Graham, All Hail the European Union: Implications of Microsoft v. Commission on Global Antitrust Enforcement, 21 Pac. McGeorge Global Bus. Dev. 285 (2008). 
cases against Microsoft was to attack Microsoft's attempted preservation of the dominance of the Windows platform, whereas in the EU the focus was on preventing Microsoft from leveraging its PC operating system monopoly into other markets, such as the group server operating system market dominated at one time by Netware and the media player market. ${ }^{16}$

\footnotetext{
${ }^{16}$ Nicholas Economides \& Ioannis Lianos, A Critical Appraisal of Remedies in the E.U. Microsoft Cases, 2010 COLUM. Bus. L. REV. 346 (2010).
} 


\section{Ortho Biotech Products, L.P. v. Amgen, Inc. ${ }^{1}$}

This case is notable because: (1) plaintiffs recovered \$200 million in settlement; (2) the private action was the only litigation; (3) the drugs at issue were very important because they offered the safest treatment for some forms of cancer.

\section{A. Factual Background}

Ortho Biotech (now Centocor Ortho Biotech; both subsidiaries of Johnson \& Johnson) and Amgen sold competing drugs called Procrit and Aranesp, respectively. These were red blood cell growth factor (RBCGF) drugs - drugs that treat anemia by regenerating red blood cells. Procrit and Aranesp were the only RBCGF drugs in existence for anemic cancer patients, so the RBCGF market was a duopoly. ${ }^{2}$ Procrit was the standard of care and indeed had been the only RBCGF oncology drug available until 2001, ${ }^{3}$ when Aranesp was first approved.

A closely related market for cancer patients was that of white blood cell growth factor (WBCGF) drugs, which regenerate white blood cells in chemotherapy-induced neutropenia. This market was monopolized by Amgen, whose WBCGF drug, Neulasta, was used in 98\% of administrations. Virtually all oncology clinics administer Neulasta with RBCGF drugs to their patients, ${ }^{4}$ as chemotherapy induces both red and white blood cell deficiencies. The alternative to administering these drugs is blood transfusions, a much costlier and medically riskier procedure. Sales of Aranesp and Procrit to oncology clinics alone exceeded \$2.5 billion in 2005.

Amgen's pricing schemes required oncology clinics to purchase at least the overwhelming majority of their total purchases of RBCGF drugs from Amgen, to then be entitled to "rebates" for Neulasta. These rebates partially or wholly lowered Neulasta's price to the rate at which Medicare would reimburse them, depending on the share of Aranesp orders represented by an oncology clinic's RBCGF drug purchases. Without the "rebates," the prices Amgen charged for Neulasta were pegged at \$300 or more in excess of Medicare's reimbursement, per dose. $^{5}$ In other words, Amgen tied the price (and discounts) for Neulasta not on its manufacturing costs or on bulk sales volumes, but on both the total volume of a clinic's RBCGF needs and the proportion of those needs that the clinic met with Aranesp rather than Procrit.

Since roughly $40 \%$ of the clinics' clients were Medicare patients, Amgen's coercive pricing scheme forced clinics to abandon Procrit for Aranesp, as they otherwise could not afford to purchase Neulasta for their patients. ${ }^{6}$ This was despite the fact that Procrit was a significantly

\footnotetext{
${ }^{1}$ Civil Action No. 05-4850 (SRC-MAS) (2005 Settlement)

${ }^{2}$ Procrit (epoetin alfa) was sold by Ortho Biotech under a perpetual exclusive license it gained from Amgen in 1985. The license covered its use for all purposes except for treating anemia in patients with renal failure. Amgen sold epoetin alfa under the brand name Epogen, to nephrology patients. Thus in the nephrology market for RBCGF drugs, Amgen held a monopoly (in its selling Epogen and Aranesp, the latter a close analogue of epoetin alfa). First Amended Complaint, at paragraph 18; Amgen Annual Reports, 2000 \& 2005 (p.3).

${ }^{3}$ Amgen 2002 Annual Report, pp. 4-5

${ }^{4}$ First Amended Complaint, paragraph 28.

${ }^{5}$ First Amended Complaint, paragraph 51.

${ }^{6}$ Id, p. 48, paragraph 15; 6 August 2007
} 
superior product as determined by independent reviews, in that patients on Procrit required "far fewer" blood transfusions than those on Aranesp. ${ }^{7}$

\section{B. Procedural Background}

Ortho Biotech filed suit on 11 October 2005 in the U.S. District Court, New Jersey, before Judge Stanley Chesler, an appointee of George W. Bush. ${ }^{8}$ Ortho Biotech alleged Section 1 (per se) and Section 2 (per se or rule of reason) violations of the Sherman Act, beginning in April 2004, when Amgen began to impose a series of increasingly punitive pricing schemes on oncology clinics, that tied the prices of Neulasta to sales of Aranesp.

We do not know of any government response: there was no government lawsuit addressing these allegations, and no government action was mentioned in the case documents filed in court.

By the commencement of the action, Ortho Biotech had rapidly lost market share-from 55\% to 34\% — since Amgen's coercive pricing scheme was first implemented. ${ }^{9}$ Because Amgen had tied the price of an essential product (over which, again, it had a monopoly) to Aranesp, Ortho would need to apply both Amgen's rebate on Aranesp, plus Amgen's discount on Neulasta on its sales of Procrit, to compete on price. This would result in below-cost pricing and drive Procrit out of the market.

From Ortho Biotech's first filing in October 2005, to May 2008, the only proceedings before the Court in this matter were pretrial discovery motions. The exceptions were Ortho Biotech's two motions seeking preliminary injunctions to restrain Amgen from enforcing its tying scheme. These motions were denied by Judge Chesler on 26 October 2005 and 21 November 2006.

On 22 July 2008, the Court dismissed the action without costs following an out-of-court settlement between the parties, in which Amgen paid Ortho Biotech \$200 million. The details of this settlement beyond the \$200 million amount are not available anywhere on the Internet, including on PACER or on Westlaw.

It is plausible that the settlement included Amgen's agreement to restructure its pricing schemes to allow Ortho Biotech to compete. This is because Amgen's alleged monopolization scheme does not seem to have succeeded in the long run. Global sales of Procrit and Aranesp were $\$ 2.2$ billion and $\$ 2.65$ billion respectively in 2009; $\$ 2.5$ billion and $\$ 3.14$ billion in 2008; and $\$ 2.9$ billion and $\$ 3.61$ billion in $2007 . .^{10}$

\section{Prior Litigation}

Two class actions based on the same alleged tying scheme by Amgen came before Judge Chesler, one on behalf of indirect purchasers of Aranesp and Neulasta (Sheet Metal Workers

\footnotetext{
${ }^{7}$ Id, paragraph 61 .

${ }^{8}$ http://en.wikipedia.org/wiki/Stanley_R._Chesler Accessed 9/22/10.

${ }^{9} \mathrm{Id}$, paragraph 37 .

${ }^{10}$ Johnson \& Johnson 2009 Annual Report, p.28, Amgen 2009 Annual Report, p.6
} 
National Health Fund $v$ Amgen Inc., filed November 2007) and the other on behalf of direct purchasers (Warren General Hospital v Amgen Inc., filed June 2010). Both failed to survive Amgen's motions to dismiss before Judge Chesler. In the latter case, the tying scheme had begun on 1/1/03 and continued to the time of filing. ${ }^{11}$ It targeted not just clinics but hospitals, doctors and other entities.

Judge Chesler's primary reason for dismissing these related actions was his view that these plaintiffs lacked standing, as they could not allege an antitrust injury. Judge Chesler based this finding by implementing the "package approach" of quantifying an antitrust injury in cases of tied products: namely, the plaintiff must show they paid more for both the tied and tying product "in a bundle than their combined market value would command.," ${ }^{2}$ He rejected the "tied product approach," in which the plaintiff must show only that damages arose from the price actually paid for the tied product, as against the tied product's price on the open market. This choice of approach was articulated by Judge Chesler as being critical to the resolution of both cases, as the plaintiffs alleged only having paid above-market prices for Aranesp. While stating that the law in this area is still unclear, Judge Chesler favored the primary rationale for the "package approach" as articulated by Areeda: "in most tying arrangements, a premium price on the tied product will be accompanied by a reduction in price on the tying product,"13 ${ }^{, 1}$ therefore there was no alleged economic harm overall. ${ }^{14}$

Judge Chesler stated, however, that " $[\mathrm{t}]$ he very nature of the tie at issue revolves around the tied goods' price interdependence, which is the underpinning of the package approach.,15 Amgen presented no evidence at any time that the cost of producing Neulasta was related to the cost of producing Aranesp, and thus no evidence that there was a legitimate business justification for the tying scheme.

There was no corresponding government action to this case or any of the related cases.

${ }^{11}$ Judgment of Judge Stanley Chesler, 6/7/10.

${ }^{12}$ Phillip E. Areeda, et al., Antitrust Law: An Analysis of Antitrust Principles and Their Application $91769 \mathrm{a}$, at 410 (2d ed.2000); In re Visa Check/MasterMoney Antitrust Litig., 280 F.3d 124, 142-43 (2d Cir.2001), cert. denied, Visa U.S.A. Inc. v. Wal-Mart Stores, Inc., 536 U.S. 917, 122 S.Ct. 2382, 153 L.Ed.2d 201 (2002)

${ }^{13}$ Ibid, 91769 c at 413.

${ }^{14}$ But see Einer Elhauge, Tying, Bundled Discounts, and the Death of the Single Monopoly Profit Theory, 123 Harv. L. Rev. 397 (2009) (demonstrating potential for harm from tying arrangements).

${ }^{15}$ Sheet Metal Workers National Health Fund v Amgen, 2008 WL 3833577 (D.N.J.), 6 


\section{OSB Antitrust Litigation ${ }^{1}$}

This case is notable because: (1) the plaintiffs recovered $\$ 120,730,000$ in settlement; (2) four of the defendants were Canadian firms; (3) this was one of the first cases to survive a challenge under Twombly; ${ }^{2}$ and (4) class counsel received \$37,091,797 plus interest (one-third of the recovery) in fees.

\section{A. Procedural Background}

In 2006, direct purchasers of Oriented Strand Board (a wood product commonly used in construction) filed a consolidated class action suit alleging a horizontal price-fixing conspiracy among the nine major OSB manufacturers ${ }^{3}$ controlling $95 \%$ of the market in North America, a per se violation of the Sherman Act. ${ }^{4}$ The plaintiffs alleged that the defendants conspired to fix, raise, maintain and stabilize OSB prices. ${ }^{5}$ The defendants did this by: (i) conspiring and agreeing to reduce the available supply of OSB in the United States to allow for and justify substantial price increases; and (ii) fixing the price of OSB through the use of a twice-weekly published price list in the leading industry publication Random Lengths. ${ }^{6}$

It was alleged that the defendants reduced the supply of OSB by (i) removing production from the market through mill shutdowns; (ii) delaying or cancelling the construction of new OSB mills; (iii) buying OSB from competitors instead of manufacturing it themselves, which they could have done at a lower cost; and (iv) having low operating rates at the mills. ${ }^{7}$

The class plaintiffs alleged that because of the defendants' unlawful conduct they paid artificially inflated prices for OSB products that they purchased from the defendants during the Class Period. $^{8}$ One direct purchaser class and two separate indirect purchaser classes-a multistate class for damages and a nationwide class for injunctive relief-were certified by Judge Diamond in the District Court for the Eastern District of Pennsylvania.

Between March 2007 and July 2008, each of the nine defendants entered into settlement agreements, with a total recovery for the class plaintiffs of $\$ 120,730,000$. The recovery breaks down by defendant as follows: Louisiana-Pacific - $\$ 44,500,000$, Weyerhaeuser - $\$ 18,000,000$, Georgia-Pacific - \$9,880,00, Potlatch - \$2,700,000, Ainsworth - \$8,600,000, Norbord $\$ 30,000,000$, Huber - \$2,000,000, Tolko - \$4,325,000, and Grant - \$725,000. ${ }^{9}$ Several class members opted out of certain of the settlement classes. ${ }^{10}$ Settlement monies were escrowed with

${ }^{1} 2007$ WL 2253419 (E.D.Pa.), 2007-2 Trade Cases P 75,845.

${ }^{2}$ Bell Atl. Corp. v. Twombly, 550 U.S. 544, 127 S.Ct. 1955, 167 L.Ed.2d 929 (2007).

3 The defendants were: Louisiana-Pacific Corporation ("Louisiana-Pacific"), Weyerhaeuser Company ("Weyerhaeuser"), Georgia-Pacific Corporation ("Georgia-Pacific"), Potlatch Corporation ("Potlatch") (On September 22, 2004, defendant Potlatch sold its OSB manufacturing facilities and related assets to Ainsworth, which was already a defendant), Norbord, J.M. Huber Corporation ("Huber"), Tolko, and Grant.

${ }^{4}$ In re OSB Antitrust Litigation, Second Consolidated Amended Class Action Complaint, 2006 U.S. Dist. Ct. ${ }^{5} I d$. at $\uparrow 2$. Pleadings 167515

${ }^{6} I d$.

${ }^{7}$ Id. at 93 .

${ }^{8} I d$. at $\llbracket 2$.

${ }^{9}$ Information from Combined Notice of Proposed Settlements with Remaining Defendants, Plan of Allocation, Petition for Attorneys' Fees, and Petition for Incentive Awards for Class Members, September 22, 2008, accessed at http://www.osbsettlement.com/pdfs/OSBNotice.pdf. Last accessed: October 25, 2010.

${ }^{10}$ In re OSB Antitrust Litigation, Slip Copy, 2009 WL 579376 (E.D.Pa.), 2009-1 Trade Cases P 76,525 [at 1]. 
respect to each opt-out. ${ }^{11}$ If an entity that opted out then pursued its own claims against a defendant, $75 \%$ of the set-aside amount was refunded to that defendant. ${ }^{12}$ The remaining $25 \%$ was made part of the settlement funds to be distributed to the class and plaintiffs' counsel. ${ }^{13}$ The Claims Administrator distributed the settlement checks on September 13, 2010. ${ }^{14}$ The litigation terminated in March 2009 and is final.

Settlements were reached with each of the defendants over the period beginning with the Huber settlement in March 2007 and ending with settlements with Louisiana-Pacific and Grant reached in July 2008. The Ainsworth, Georgia-Pacific and Tolko settlements were finally approved in August 2008 and the remainder were finally approved on 9 December 2008. The attorney's fees were awarded on the same day.

A total of $\$ 43,650,000$ was recovered from defendants based in Canada (Ainsworth, Norbord, Tolko and Grant).

The defendants filed a motion to dismiss, which was denied in September $2006 .{ }^{15}$ The defendants initially filed the motion before the Supreme Court's Twombly case had been decided and the motion was denied without prejudice to the defendants' right to renew the motion. ${ }^{16}$ The defendants renewed the motion immediately following the Twombly ruling. Judge Diamond concluded that the direct and indirect purchaser plaintiffs had satisfied the Twombly pleading standard by stating a claim to relief that is plausible on its face. ${ }^{17}$

A direct purchaser class was certified as follows: "All individuals and entities who purchased OSB structural panel products in the United States directly from Defendants during the Class Period from June 1, 2002 through the present. For group buying organizations and their members, direct purchasers are either: (1) members who have a significant ownership interest in or functional control over their organizations; or (2) if no member has such interest or control, the organizations themselves. Excluded from the Class are Defendants, their co-conspirators, their respective parents, subsidiaries, and affiliates, and any government entities."18

A multistate indirect purchaser class for damages was certified as follows: “All residents of the following states who, as end users, indirectly purchased for their own use, and not for resale, new OSB manufactured and sold by one or more of the defendants between June 1, 2002 and the present (the 'Class Period'): Iowa, Kansas, Maine, Michigan, Mississippi, North Carolina, North Dakota, and Tennessee. Excluded from the Class are: all federal, state, or local governmental entities; Defendants and subsidiaries and affiliates of Defendants; all persons who purchased OSB directly from any Defendant or from any other manufacturer of OSB; all buying groups or co-operatives and all persons who purchased OSB through, or as part of, any buying groups or co-operatives; and all persons who purchased OSB only as part of a house or other structure. The Class shall be divided into subclasses by state."19

${ }^{11} I d$.

${ }^{12} I d$.

${ }^{13} \mathrm{Id}$.

${ }^{14}$ Information found on http://www.osbsettlement.com/. Last accessed: October 25, 2010.

${ }^{15}$ In re OSB Antitrust Litigation, Not Reported in F.Supp.2d, 2007 WL 2253419 (E.D.Pa.), 2007-2 Trade Cases P 75,845 [at 1].

${ }^{16} I d$.

${ }^{17} \mathrm{Id}$. [at 6].

${ }^{18}$ In re OSB Antitrust Litigation, Not Reported in F.Supp.2d, 2007 WL 2253418 (E.D.Pa.), 2007-2 Trade Cases P 75,844 [at 10].

${ }^{19}$ In re OSB Antitrust Litigation, Not Reported in F.Supp.2d, 2007 WL 2253425 (E.D.Pa.), 2007-2 Trade Cases P

75,843, 68 Fed.R.Serv.3d 1008 [at 19]. 
A nationwide indirect purchaser class for injunctive relief was certified as follows: “All persons in the United States who, as end users, indirectly purchased for their own use, and not for resale, new OSB manufactured and sold by one or more of the defendants between June 1, 2002 and the present (the 'Class Period'). Excluded from the Class are: all federal, state, or local governmental entities; Defendants and subsidiaries and affiliates of Defendants; all persons who purchased OSB directly from any Defendant or from any other manufacturer of OSB; all buying groups or co-operatives and all persons who purchased OSB through, or as part of, any buying groups or co-operatives; and all persons who purchased OSB only as part of a house or other structure."20

There was no amount computed for the overcharge.

Class counsel were awarded \$37,091,797 plus interest in attorney's fees, i.e., one third of the total settlement monies available to direct purchaser class Members, to be divided according to a court approved plan between the thirty-eight firms that represented direct purchaser plaintiffs. $^{21}$

This case was brought as a violation of section 1 of the Sherman Act under the per se rule.

Judge Diamond presided over this case. Judge Diamond was nominated by George W. Bush (a Republican).

When certifying the classes, Judge Diamond noted that: "[t]o date, Lead and Co-Lead Counsel have vigorously and capably prosecuted this extremely demanding litigation, and I am satisfied that they will continue to do so."22 Further, when finally approval the settlement plan Judge Diamond reiterated: "[c]lass counsel have represented their clients with consummate skill and efficiency, bringing this massive matter to conclusion in less than three years." 23 However, the court insisted that counsel file an allocation plan for approval by the court, in light of disputes between class counsel, and when counsel filed for allocation of further fees from the opt-out fund, Judge Diamond refused the request, explaining that he had already approved sufficient fees. $^{24}$

${ }^{20} I d$.

${ }^{21}$ Over \$12.6 million in fees went to Lead Counsel - Spector Roseman Kodroff \& Willis, P.C. Co-Lead Counsel, Cohen Milstein Sellers \& Toll, P.L.L.C., received over \$3.1 million in fees. The remaining thirty-six firms representing the Direct Purchaser Plaintiffs shared in the remainder of the \$37 million counsel fee award. In re OSB Antitrust Litigation, Slip Copy, 2009 WL 579376 (E.D.Pa.), 2009-1 Trade Cases P 76,525 [at 1 ].

${ }^{22}$ In re OSB Antitrust Litigation, Not Reported in F.Supp.2d, 2007 WL 2253418 (E.D.Pa.), 2007-2 Trade Cases P 75,844 [at 4].

${ }^{23}$ Final Approval Order can be found at: http://amlawdaily.typepad.com/ospfeeallocationorder.pdf.

${ }^{24}$ In re OSB Antitrust Litigation, Slip Copy, 2009 WL 579376 (E.D.Pa.), 2009-1 Trade Cases P 76,525 [at 4]. 


\section{Scrap Metal Antitrust Litigation ${ }^{1}$}

This case is notable because: (1) the plaintiffs received a total recovery of $\$ 34,500,000$; (2) the attorneys representing plaintiffs were awarded $\$ 7,335,000$ for fees and costs (overall 21\%); (3) the case involved related government investigations and convictions; and (4) plaintiffs won a class action trial that was affirmed on appeal.

\section{A. Factual Background}

Manufacturing processes for products made out of metal generate scrap metal, both ferrous and non-ferrous, as a byproduct. ${ }^{2}$ This scrap metal can be sold to mills and foundries, which recycle the scrap metal in manufacturing new metal products. ${ }^{3}$ Due to this production of scrap metal, Plaintiffs engage in the purchase, brokering, and sale of scrap metal. ${ }^{4}$

The sale of scrap metal in the market takes place as follows: the dealer submits bids to the generators for the purchase of unprocessed scrap during a specified time period at a set price. ${ }^{5}$ In setting their bid prices, dealers consult various trade publications, such as American Metal Market and Iron Age magazine, which report the prevailing prices that dealers can expect to charge users for the scrap after they have processed it. ${ }^{6}$ To ensure they turn a profit, dealers set their bid price for the unprocessed scrap below the amount they will ultimately charge the users for the unprocessed scrap. ${ }^{7}$ If the bid is accepted by the scrap generator, the generator and the dealer enter into a contract at the bid price for the bid period. ${ }^{8}$ The purchasers of the scrap will then leave collection boxes at the manufacturer's site. After the boxes are filled with scrap metal by the manufacturers, the purchasers will weigh the boxes and then resell the scrap to mills and foundries. ${ }^{9}$

\section{B. Related Actions}

In 1995, the Government investigated a Cleveland-area scrap metal shredder for conspiring to fix the price of scrap metal. ${ }^{10}$ The investigation resulted in a conviction, which then spawned another investigation for conspiracies involving other scrap metal dealers in Northeast Ohio. ${ }^{11}$ The investigation resulted in plea agreements from Bay Metal, Inc. and Howard Bahm. $^{12}$ On June 21, 2000, Judge Donald C. Nugent of the Northern District of Ohio rendered a disposition on Bay Metals, Inc., and sentenced them to probation for 3 years, a fine of

\footnotetext{
${ }^{1}$ C.A. No. 01:02-0844 (N.D. Ohio 2002).

${ }^{2}$ In re Scrap Metal Antitrust Litigation, 527 F.3d 517, 523 (6th Cir. 2008).

${ }^{3}$ In re Scrap Metal Antitrust Litigation, 2006 WL 2850453, C.A. No. 02-0844, Order Denying Motion for Judgment as a Matter of Law, 9/30/2006, at p. 2.

${ }^{4}$ In re Scrap Metal Antitrust Litigation, C.A. No. 02-0844, Complaint, 5/3/2002, at 6.

${ }^{5}$ In re Scrap Metal Antitrust Litigation, 527 F.3d at 523.

${ }^{6}$ Id. at 523-525.

${ }^{7} \mathrm{I} d$. at 523 .

${ }^{8}$ Id.

${ }^{9}$ In re Scrap Metal Antitrust Litigation, C.A. No. 02-0844, Second Amended Consolidated Class Action Complaint, $4 / 30 / 2003$, at 39.

${ }^{10}$ In re Scrap Metal Antitrust Litigation, C.A. No. 02-0844, Order Granting Government’s Motion to Intervene, $11 / 7 / 2002$, at p. 2.

${ }^{11}$ Id.

${ }^{12} \mathrm{Id}$.
} 
$\$ 850,000$ to the USA payable in 4 installment payment, and a special assessment of $\$ 4,000$. $^{13}$ On August 30, 2001, Howard Bahm entered into a plea agreement on four counts of supplier allocation and bid rigging in violation of section 1 of the Sherman Act, 15 U.S.C. $\S 1 .{ }^{14}$ On October 7, 2005, Judge Nugent sentenced Bahm to two years of probation on each count to run concurrently, a fine of $\$ 1,000,000$, and a special assessment of $\$ 400 .{ }^{15}$

\section{Procedural History}

\section{i. Preliminary Pleadings}

On July 25, 2002, Judge Kathleen O’Malley ordered four complaints by Lincoln Electric Company, Bic Manufacturing, Inc., and Mid-West Material, Inc., consolidated into a single action with the earliest case against the common defendants filed by Profile Grinding, Inc. ${ }^{16}$

On August 15, 2002, the original class plaintiffs filed an Amended Consolidated Class Action Complaint in the federal district court in the Northern District of Ohio against eight defendants. ${ }^{17}$ The original named plaintiffs for the class were as follows: Lincoln Electric Company ("Lincoln”); Shiloh Industries, Inc. (“Shiloh”); Profile Grinding, Inc. ("Profile”); Bic Manufacturing, Inc. ("Bic”); and Talan Products, Inc. ("Talan”). ${ }^{18}$ The original class plaintiffs claimed that the defendants' conspiracy from December 1992 through March 2000 was a per se violation of section 1 of the Sherman Act, 15 U.S.C. $\S 1 .{ }^{19}$ In the alternative, the original class plaintiffs claimed that defendants' conduct constituted a violation of the same provision under the rule of reason. ${ }^{20}$ The original class plaintiffs attempted to recover damages jointly, severally, and trebled in amount pursuant to section 4 of the Clayton Act, 15 U.S.C. $\S 15 .^{21}$

On April 15, 2003, class plaintiff Mid-West’s motion for voluntary dismissal without prejudice was granted. ${ }^{22}$ Mid-West requested dismissal because it had entered into merger discussion with the Columbia Defendants, ${ }^{23}$ which caused a conflict with its posture as a participant in the litigation. ${ }^{24}$ Mid-West was also using dismissal of the litigation as a term of the merger. ${ }^{25}$ This dismissal prompted the filing of a Second Amended Consolidated Class Action

${ }^{13}$ USA v. Bay Metals, Inc., C.R. No. 00-0130, N.D. Ohio 2000.

${ }^{14}$ USA v. Bahm, C.R. No. 01-0393, N.D. Ohio 2001.

${ }^{15}$ USA v. Bahm, C.R. No. 01-0393, Judgment in a Criminal Case, 10/7/2005, at pp. 2-4.

${ }^{16}$ In re Scrap Metal Antitrust Litigation, C.A. No. 02-0844, 7/25/2002, Order Consolidating Cases.

${ }^{17}$ The defendants were as follows: Bay Metals, Inc.; Harry Rock \& Associates, Inc.; M. Weingold \& Co., Inc.; Jack Weingold; Columbia National Group, Inc.; Atlas Lederer Company, Inc.; Columbia Iron \& Metal Company; and Columbia Trading, Inc. In re Scrap Metal Antitrust Litigation, C.A. 02-0844, Amended Consolidated Class Action Complaint, 8/15/2002, at 10-17.

${ }^{18}$ In re Scrap Metal Antitrust Litigation, C.A. No. 02-0844, 8/15/2002, Amended Consolidated Class Action

Complaint, at 4-9.

${ }^{19}$ Id. at $45-48$.

${ }^{20} \mathrm{Id}$. at 49 .

${ }^{21}$ Id. at C.

${ }^{22}$ In re Scrap Metal Antitrust Litigation, C.A. No. 02-844, Order Granting Motion to Dismiss Mid-West Materials, Inc. as a Plaintiff, 4/15/2003, at p. 3.

${ }^{23}$ Columbia National Group, Inc.; Columbia Iron \& Metal Company; and Columbia Trading, Inc.

${ }^{24}$ In re Scrap Metal Antitrust Litigation, C.A. No. 02-844, Order Granting Motion to Dismiss Mid-West Materials, Inc. as a Plaintiff, 4/15/2003, at p. 1.

${ }^{25} I d$. 
Complaint by Lincoln, Profile, Bic, and Talan (“Class Plaintiffs"). ${ }^{26}$ The defendants were as follows: Bay Metal, Inc.("Bay Metal”); Bluestar Metal Recycling Co. ("Bluestar”); DeMilta Iron \& Metal ("DeMilta”); Harry Rock \& Associates, Inc. ("Harry Rock”); M. Weingold \& Co., Inc. ("M. Weingold”); Jack Weingold; Columbia National Group, Inc. (“Columbia National”); Atlas-Lederer Company, Inc. (“Atlas-Lederer”); Columbia Iron \& Metal Company (“Columbia Iron”); Columbia Trading, Inc. (“Columbia Trading”); Philip Metals, Inc. (“Philip”); and Parkwood Iron \& Metal, Inc. ("Parkwood”). ${ }^{27}$

Based upon their own investigations, the Class Plaintiffs alleged that, beginning around December 1992, the defendants conspired to fix the price of scrap metal through conspiracy and suppression of competition. ${ }^{28}$ In furtherance of this conspiracy, the Class Plaintiffs asserted the defendants took part in the following actions: (1) participated in meetings and conversations to allocate customers and rig bids; (2) participated in meetings and conversations to set pricing for the purchase of scrap; (3) agreed to sell the losing bidder specified volumes of scrap at favorable pricing; (4) submitted rigged and collusive bids; (5) intimidated other scrap dealers not to offer competitive bids; (6) directed employees not to compete for certain customers; (7) imposed penalties for violation of conspiracy agreements; and (8) concealed the conspiracy through withholding information from government investigation. ${ }^{29}$

Class Plaintiffs also pointed to four different events that indicate a conspiracy. It is first alleged that in 1993 Weingold secretly met with Bay Metals to submit a non-competitive bid, concealed the collusion, and created the false impression the bid was fair. ${ }^{30}$ Secondly, it is alleged that also in 1993 Atlas Lederer employees were directed not to compete for an account because it "belonged" to another scrap dealer. ${ }^{31}$ Next, in 1995, Columbia National directed Atlas-Lederer to retract its bid to allow Weingold to retain a contract and in return was given a contract with Weingold for volumes of scrap. ${ }^{32}$ Finally, in 1996, Rock arranged for at least one other scrap dealer to submit a bid to make Rock's bid look legitimate. ${ }^{33}$

\section{ii. Class Certification}

On March 31, 2004, the Class Plaintiffs' motion to certify the class was granted by the court. $^{34}$ The court defined the class as follows: "all persons or entities with scrap generating facilities in Northeast Ohio and the surrounding counties, which is comprised of Ashtabula, Cuyahoga, Lake, Lorain, Medina, Stark and Summit counties, who sold ferrous or nonferrous industrial scrap metal to Defendants between December 1992 and March 2000. Excluded from the Class are Defendants, and their respective parents, subsidiaries and affiliates, as well as any governmental entities. Also excluded from the Class is any party, whether named or not, who is ultimately deemed to have participated in an illegal conspiracy.",35

\footnotetext{
${ }^{26}$ In re Scrap Metal Antitrust Litigation, C.A. No. 02-844, Second Amended Consolidated Class Action Complaint, $4 / 30 / 2003$, at $4-7$

${ }^{27}$ Id. at 8-19.

${ }^{28}$ In re Scrap Metal Antitrust Litigation, C.A. No. 02-844, Order Granting Class Certification, 3/31/2004, at p. 3.

${ }^{29} I d$.

${ }^{30} I d$. at 4 .

${ }^{31} I d$.

${ }^{32} I d$.

${ }^{33} \mathrm{Id}$.

${ }^{34}$ In re Scrap Metal Antitrust Litigation, C.A. No. 02-844, Order Granting Class Certification, 3/31/2004.

${ }^{35}$ Id. at p. 2.
} 


\section{iii. Settlement}

a. Bay Metal, Inc.

On November 17, 2003, Bay Metal filed a proposed settlement agreement with the court, a few months before the certification of the class by the court. ${ }^{36}$ The Class $^{37}$ was initially paid $\$ 300,000.00$ into an escrow account for the settlement of the action. ${ }^{38}$ The settlement agreement stated that additional payments would be made to the class upon preliminary approval, at which time 55\% of BMI's adjusted net income for 2003, 2004, and 2005 would be entered in the escrow account, subject to a maximum of $\$ 900,000$ total. $^{39}$ The court gave preliminary approval of the settlement between the parties on May 20, 2004, ${ }^{40}$ and final approval on November 12 , $2004 .^{41}$

The plan for allocation provided that class members would receive a pro rata share of the settlement fund after costs and fees had been removed, and can qualify for their share by filing timely proof of claims forms. ${ }^{42}$ The claim shares would be based upon the total number of valid claims submitted and the total amount paid by those submitting claims. ${ }^{43}$

The settlement agreement allowed for the court to decide the payment of fees and costs. ${ }^{44}$ On March 24, 2005, the court issued an order awarding attorney's fees to Class Plaintiff's counsel for this settlement and the Weingold Settlement, which is discussed in detail below. ${ }^{45}$

\section{b. Weingold Defendants}

On April 23, 2004, the Weingold Defendants ${ }^{46}$ filed a proposed settlement agreement with the court, about a month after the court had certified the class. ${ }^{47}$ The Class ${ }^{48}$ was paid $\$ 9.9$

\footnotetext{
${ }^{36}$ In re Scrap Metal Antitrust Litigation, C.A. No. 02-844,

${ }^{37}$ The Bay Metal Settlement Class was defined as follows: “All persons or entities located in Northeast Ohio and the surrounding counties, which is composed of Ashtabula, Cuyahoga, Lake, Lorain, Medina, Stark and Summit counties, who sold ferrous or nonferrous industrial scrap metal to Defendants and/or their co-conspirators between December 1992 and March 2000, or such other substantially similar class as may be certified by the Court.” In re Scrap Metal Antitrust Litigation, C.A. No. 02-844, BMI Settlement Agreement, 11/17/2003, at p. 3.

${ }^{38}$ Id. at p. 6.

${ }^{39}$ Id. at pp. 5-6.

${ }^{40}$ In re Scrap Metal Antitrust Litigation, C.A. No. 02-844, Order Granting Preliminary Approval of Proposed Settlement with BMI and Weingold, 5/20/2004.

${ }^{41}$ In re Scrap Metal Antitrust Litigation, C.A. No. 02-844, Order Granting Final Approval of Settlement with BMI, $11 / 12 / 2004$.

${ }^{42}$ In re Scrap Metal Antitrust Litigation, C.A. No. 02-844, Plan of Distribution for Weingold and BMI, 12/30/2004, at p. 6-7.

43 Id.

${ }^{44}$ In re Scrap Metal Antitrust Litigation, C.A. No. 02-844, BMI Settlement Agreement, 11/17/2003, at p. 6.

${ }^{45}$ In re Scrap Metal Antitrust Litigation, C.A. No. 02-844, Order Awarding Attorneys’ Fees and Reimbursement of Expenses

46 “Weingold Defendants” are comprised of M. Weingold \& Co., Harry Rock and Associates, Inc., and jack Weingold. Id. at p. 1.

${ }^{47}$ In re Scrap Metal Antitrust Litigation, C.A. No. 02-0844, Weingold Settlement Agreement, 4/23/2004

48 The Weingold Settlement Class was defined as follows: “All persons or entities who sold ferrous or nonferrous industrial scrap metal in Northeast Ohio and the surrounding counties, comprised of Ashtabula, Cuyahoga, Lake, Lorain, Medina, Stark and Summit Counties, to Defendants and/or their co-conspirators between December 1992 and March 2000, or such other substantially similar class as may be certified by the Court.” Id. at p. 3.
} 
million into a settlement escrow fund. ${ }^{49}$ The court gave preliminary approval of the settlement between the parties on May 20, 2004, ${ }^{50}$ and final approval on November 12, $2004 .^{51}$ On February 15, 2005, Judge O'Malley granted Weingold's motion to enforce, causing Impact Industries, Inc. to be enjoined from proceeding with its previously filed state court action captioned Impact Industries, Inc. v. M. Weingold \& Co., Case No. CV 04547946 (Cuyahoga County Common Pleas Court, Ohio). ${ }^{52}$

The plan for allocation provided that class members would receive a pro rata share of the settlement fund after costs and fees had been removed, and can qualify for their share by filing timely proof of claims forms. ${ }^{53}$ The claim shares would be based upon the total number of valid claims submitted and the total amount paid by those submitting claims. ${ }^{54}$

Like the Bay Metal settlement agreement, the Weingold settlement agreement provided for the court to determine attorney's fees and costs. ${ }^{55}$ On March 24, 2005, the court awarded Plaintiff's counsel fees in the amount of $\$ 3,060,000$, which is $30 \%$ of the total partial settlements of $\$ 10,200,000.00$ between Weingold and Bay Metal. ${ }^{56}$ The court also awarded expenses in the amount of $\$ 1,614,719 .^{57}$ Named plaintiff Lincoln received an incentive award of $\$ 20,000.00$, and named plaintiff Profile Grinding an incentive award of $\$ 10,000.00 .^{58}$

\section{c. Bluestar Metals Recycling Co.}

On December 20, 2005, Bluestar filed a proposed settlement agreement with the court, days before filing their pre-trial pleadings. ${ }^{59}$ The Class $^{60}$ was paid a total of $\$ 350,000$, to be made in five payments of $\$ 70,000$ each. ${ }^{61}$ The first payment was made 14 days after full execution of the settlement agreement, with each subsequent payment made six months after the previous payment. ${ }^{62}$ The court gave preliminary approval of settlement between the parties on November 17, 2006, ${ }^{63}$ and final approval on April 7, 2011. ${ }^{64}$

${ }^{49}$ In re Scrap Metal Antitrust Litigation, C.A. No. 02-844, Weingold Settlement Agreement, 4/23/2003, at p. 7.

${ }^{50}$ In re Scrap Metal Antitrust Litigation, C.A. No. 02-844, Order Granting Preliminary Approval of Proposed Settlement with BMI and Weingold, 5/20/2004.

${ }^{51}$ In re Scrap Metal Antitrust Litigation, C.A. No. 02-844, Order Granting Final Approval of Settlement with BMI, $11 / 12 / 2004$.

${ }^{52}$ In re Scrap Metal Antitrust Litigation, C.A. No. 02-844, Order Enjoining Impact Industries, 2/15/2005, at p. 1.

${ }^{53}$ In re Scrap Metal Antitrust Litigation, C.A. No. 02-844, Plan of Distribution for Weingold and BMI, 12/30/2004, at p. 6-7.

${ }^{54} \mathrm{Id}$.

${ }^{55}$ In re Scrap Metal Antitrust Litigation, C.A. No. 02-844, Weingold Settlement Agreement, 4/23/2004, at pp. 6-7.

${ }^{56}$ In re Scrap Metal Antitrust Litigation, C.A. No. 02-844, Order Awarding Attorneys' Fees and Reimbursement of Expenses, 3/24/2005, at p. 1.

${ }^{57} I d$.

${ }^{58}$ In re Scrap Metal Antitrust Litigation, C.A. No. 02-0844, Order Approving Plan of Allocation, 7/12/2005.

${ }^{59}$ In re Scrap Metal Antitrust Litigation, C.A. No. 02-844, Bluestar Settlement Agreement, 12/20/2005.

${ }^{60}$ The Bluestar Settlement Class was defined as follows: "All persons or entities with scrap generating facilities located in Northeast Ohio and the surrounding counties, which is comprised of Ashtabula, Cuyahoga, Lake, Lorain, Medina, Stark and Summit counties, who sold ferrous and nonferrous industrial scrap metal to Defendants between December 1992 and March 2000. Excluded from the Class are Defendants, and their respective parents, subsidiaries and affiliates, as well as any governmental entities. Also excluded from the Class is any party, whether named or not, who is ultimately deemed to have participated in an illegal conspiracy.” Id. at p. 3.

${ }^{61} I d$. at p. 6.

${ }^{62} I d$.

${ }^{63}$ In re Scrap Metal Antitrust Litigation, C.A. No. 02-844, Order Preliminarily Approving Proposed Settlement with Bluestar Metals Recycling Co., 11/17/2006. 


\section{iv. Pre-Trial Through Post-Trial}

On December 9, 2005, prior to the filing of the pre-trial pleadings, the Columbia Defendants $^{65}$ filed a motion for summary judgment. ${ }^{66}$ The same day, DeMilta Iron \& Metal also filed a summary judgment motion. ${ }^{67}$ Both motions were denied on January 20, 2006. ${ }^{68}$

After a jury trial, the jury returned a verdict regarding DeMilta and the Columbia Defendants. The jury found that Columbia Iron \& Metal Co. and Columbia Trading were involved in the conspiracy, and that Columbia National and DeMilta were not involved in the conspiracy. ${ }^{69}$ After finding that those involved in the conspiracy had created a substantial injury to Class Plaintiffs, the jury awarded $\$ 11,500,000.00$ in damages. ${ }^{70}$ The award was trebled pursuant to 15 U.S.C. $\S 15$ (a) to $\$ 34,500,000.00$, then offset by $\$ 11,464,000.00$ in other settlements, making the total award $\$ 23,036,000.00 .^{71}$ Judgment was entered in favor of Columbia National and DeMilta by the court on February 14, 2006. ${ }^{72}$

On February 27, 2006, Columbia Iron \& Metal filed a motion for new trial and renewed its motion for judgment as a matter of law. ${ }^{73}$ On September 30, 2006, after extensive briefing, the trial court denied both motions. ${ }^{74}$ The court felt that numerous wasteful arguments were made by Columbia Iron \& Metal, and summarily dismissed several of them based on the trial record.

On September 30, 2006, the trial court awarded attorney’s fees of $\$ 2,529,820.85$. $^{76}$ Plaintiffs sought a total of \$3,103,247.51 in attorney's fees, but because of deficiencies relating to "other firm time" and "travel expenses” from Plaintiffs' request for fees, the court granted a $2.5 \%$ overall deduction of the requested amount and a $30 \%$ specific deduction to the travelrelated fees. ${ }^{77}$ The court also awarded $\$ 130,575.34$ in costs. ${ }^{78}$ Plaintiffs sought a total of $\$ 137,477.72$ in costs, but due to excessive "service" costs, the court awarded a 5\% overall deduction of approximately $\$ 6,800.00$ from the requested amount. ${ }^{79}$

On October 27, 2006, Columbia Iron \& Metal filed its Notice of Appeal. ${ }^{80}$

${ }^{64}$ In re Scrap Metal Antitrust Litigation, C.A. No. 02-844, Order Approving Proposed Settlement With Bluestar Metals and Directing Entry of Judgment, 4/7/2011.

${ }^{65}$ Columbia National Group, Inc.; Columbia Iron \& Metal Company; Columbia Trading, Inc.

${ }^{66}$ In re Scrap Metal Antitrust Litigation, C.A. No. 02-844, Columbia Defendants' Motion for Summary Judgment, $12 / 9 / 2005$.

${ }^{67}$ In re Scrap Metal Antitrust Litigation, C.A. No. 02-844, DeMilta Iron \& Metal Motion for Summary Judgment, 12/9/2005.

${ }^{68}$ In re Scrap Metal Antitrust Litigation, C.A. No. 02-844, Order Denying Motion for Summary Judgment, $1 / 20 / 2006$.

${ }^{69}$ In re Scrap Metal Antitrust Litigation, C.A. No. 02-844, Jury Verdict, 2/9/2006, at p. 2.

${ }^{70}$ Id. at p. 7.

${ }^{71}$ In re Scrap Metal Antitrust Litigation, C.A. No. 02-844, Judgment in a Civil Case, 2/10/2006.

${ }^{72}$ In re Scrap Metal Antitrust Litigation, C.A. No. 02-844, Judgment Entry in Favor of Defendants, 2/14/2006.

${ }^{73}$ In re Scrap Metal Antitrust Litigation, C.A. No. 02-844.

${ }^{74}$ In re Scrap Metal Antitrust Litigation, C.A. No. 02-844, Order Denying Motion for Judgment as a Matter of Law, 9/30/2006.

${ }^{75}$ Id. at p. 8-9.

${ }^{76}$ In re Scrap Metal Antitrust Litigation, C.A. No. 02-844, Order Granting Motion for Attorneys' Fees, 9/30/2006, at p. 22.

${ }^{77}$ Id. at $18-19$.

${ }^{78}$ Id. at p. 22.

${ }^{79} \mathrm{Id}$. at 12.

${ }^{80}$ In re Scrap Metal Antitrust Litigation, C.A. No. 02-844, Notice of Appeal, 10/27/2006. 


\section{v. Appeal}

On May 15, 2008, the Sixth Circuit of the United States Court of Appeals affirmed the decision court. $^{81}$

${ }^{81}$ In re Scrap Metal Antitrust Litigation, 527 F. 3rd 517 (6th Cir. 2008). 


\section{Tobacco (DeLoach v. Philip Morris Cos.) $)^{1}$}

This case is notable because: (1) the plaintiffs received a total in damages of $\$ 310$ million in cash; (2) the plaintiffs' attorneys were awarded \$84 million in attorneys' fees and expenses (overall 27\%); (3) the Settlements included a commitment by the manufacturers to purchase annually a minimum of 160 million pounds of tobacco from Class members for 12 years ("Volume Commitment"), ${ }^{2}$ and the First Settlement provided an additional \$2 million for the class to monitor compliance with the Volume Commitment; ${ }^{3}$ (4) the First Settlement also established an \$8 million trust, of which \$3 million was for education and research activities, and $\$ 5$ million for Class Counsel to pursue a "legislative buyout" of the Federal Tobacco Program; ${ }^{4}$ and (5) as a result of Class Counsel's effort, Congress passed the Fair and Equitable Tobacco Reform Act of 2004.

\section{A. Current Litigation}

\section{i. $\quad$ Preliminary Proceedings}

This litigation was initiated approximately two years after the Department of Justice announced its investigation of Philip Morris, B\&W, RJR, and Universal for colluding to fix the price of tobacco. Several of the Defendants were also subject to a separate investigation for making false statements to Congress during hearings on the Federal Tobacco Program. Neither investigation appears to have produced any further developments.

The categories of Plaintiffs included growers (i.e., quota holders) and domestic producers of leaf tobacco. Neither the settlement documents nor the distribution reports, available on the docket, specify the amounts allocated to categories of Plaintiffs or individual Plaintiffs.

Plaintiffs originally filed on February 16, 2000 in the US District Court for the District of Columbia, Doc. No, 1:00CV00294, but Defendants successfully moved for the case to be transferred to the Middle District of North Carolina. The case was transferred to the MDNC and assigned to Judge William L. Osteen, Sr. on December 7, 2000.

Plaintiffs filed a class action, on behalf of over 170,000 leaf tobacco farmers, against four major tobacco manufacturers, including Philip Morris, Lorillard, Brown \& Williamson (“B\&W”), and

\footnotetext{
${ }^{1}$ No. 1:00CV01235, 2004 WL 5508762 (M.D.N.C. Mar. 31, 2005)

${ }^{2}$ First Settlement $\S 4.1-4.2$. The original Volume Commitment of 405 million pounds carried an estimated value of $\$ 1$ billion for the Class. However, pursuant to the Fourth Circuits ruling on the affect of the RJR Settlement on the MFN, the District Court reduced the commitment of each settling Manufacturer (i.e. all but RJR) by 67.81\%.

Therefore, the total Volume Commitment under the First Settlement was reduced from 405 million pounds to 130 million pounds annually. The length of the commitment was later extended to 12 years, due to the enactment of the federal tobacco buyout. By the author's calculations, these adjustments, in addition to the RJR Volume Commitment, brought the total estimated value of the Volume Commitments to over \$484 million.

${ }^{3}$ First Settlement, at $\S 4.9$.

${ }^{4} I d$. at $\S 5.2$.

${ }^{5}$ Price-Fixing Inquiry Into Leaf Tobacco Is Expanded by US, The Wall Street Journal, Sept. 21, 1998, at B2; Agency Confirms Inquiry of Tobacco Leaf Prices, The Wall Street Journal, February 2, 1998, at C20.
} 
RJ Reynolds ("RJR”) ("Manufacturers”), and several leaf merchants ("Buyers”), asserting claims under sections 1 and 2 of the Sherman Act. ${ }^{7}$ All Defendants were domestic corporations.

Plaintiffs asserted that the alleged conspiracy, among the Defendant Manufacturers and Buyers, to fix the price of tobacco, and to reduce tobacco quotas, constituted a violation of sections 1 and 2 of the Sherman Act under both per se and rule of reason standards. ${ }^{9}$

Plaintiffs alleged that, from 1996 to at least 2001, Defendants conspired to fix prices at tobacco auctions, and to reduce tobacco quotas in violation of Sherman $\S 1 .{ }^{10}$ In addition, Plaintiffs claimed that Philip Morris abused its monopsony power or, alternatively, that the Manufacturers abused their oligopsony power in violation of Sherman $\S 2 .^{11}$

Plaintiffs alleged that Philip Morris violated Sherman $\S 1$ by conspiring to reduce the price of tobacco through bid-rigging at tobacco auctions. ${ }^{12}$ According to Plaintiffs, Defendants met before auctions to coordinate their bids. Plaintiffs asserted that at such meetings, Philip Morris instructed the other manufacturers on the price to be submitted at auction, and that the manufacturers directed their buyers to not exceed that price or bid against Philip Morris's buyer. Philip Morris's buyer almost always bid first, generally submitting an offer close to the USDA minimum. The other buyers followed by placing identical bids. ${ }^{13}$ Defendants met again after auctions to reallocate the amounts purchased, so that each manufacturer received its desired amount at the agreed upon price.

Plaintiffs claimed that Philip Morris violated Sherman $\S 2$ by abusing its monopsony power. Philip Morris controlled 49\% of the domestic cigarette market, and purchased approximately $65 \%$ of domestically produced tobacco. ${ }^{14}$ The Famers theorized that Philip Morris possessed the financial resources and industry clout to dictate auction prices and allocations to the other Manufacturers, and to force the Buyers to cooperate with the agreement. ${ }^{15}$ Therefore, Philip Morris allegedly abused its monopsony power by engaging in the conduct described above.

In the alternative, Plaintiffs contended that the manufacturers violated Sherman $\S 2$ by abusing their oligopsony power. ${ }^{16}$ Together, the four manufacturers controlled approximately $96 \%$ of the market, and purchased at least $95 \%$ of the domestically grown tobacco. ${ }^{17}$ Plaintiffs further alleged that the manufacturers abused their oligopsony power by withholding business from or admonishing leaf buyers that bid higher than the agreed upon price. ${ }^{18}$

\footnotetext{
${ }^{6}$ The Defendant Buyers were: Universal Leaf Tobacco Co (“Universal”); J.P. Taylor, Inc. (“Taylor”); Southwestern, Inc.(“Southwestern”); DIMON Incorporated ("DIMON”); and, Standard Commercial Corp. (“Standard”).

${ }^{7}$ DeLoach v. Philip Morris Cos., 2001 WL 1301221, at *1 (M.D.N.C. July 24, 2001).

${ }^{8}$ See Third Amended Complaint, 2000 WL 34015502 (M.D.N.C. Dec. 7, 2000).

${ }^{9}$ Third Amended Complaint, 2000 WL 34015502, at *1.

${ }^{10}$ Id. at $* 1-5$.

${ }^{11} I d$.

${ }^{12} I d$.

${ }^{13} \mathrm{Id}$.

${ }^{14}$ Id. at $* 14$

${ }^{15}$ Id. at *15-16 ("Plaintiffs support this contention with the allegation that Philip Morris finances the industry's collective litigation and lobbying efforts.”).

${ }^{16}$ Id. at $* 16$.

${ }^{17}$ RJR had approximately $24 \%$ market share and purchased approximately $10-15 \%$. B\&W had approx. 14\% market share and also purchased $10-15 \%$. Lorillard had a $9 \%$ share of the market and purchased $10-15 \%$. Id. at *14,16.

${ }^{18} 2001$ WL 1301221, at *16.
} 
Since the alleged conspiracy was on the buying side, no overcharge was at issue. Rather, Plaintiffs asserted that the conspiracy resulted in the artificial reduction of tobacco prices at auction, and reduced tobacco quotas. Plaintiffs did not specify the amount of the price reduction.

\section{ii. Motion to Dismiss}

In 2001, Defendants filed joint motions to dismiss Plaintiffs’ Third Amended Complaint for failure to state a claim under the Sherman Act. On July 24, 2001, the Court denied Defendants' motions to dismiss, finding that Plaintiffs had alleged sufficient facts to support their claims under both sections 1 and 2 of the Sherman Act. ${ }^{19}$ The Court accepted Plaintiffs' assertion that the alleged conspiracy constituted a per se violation of the Sherman Act. ${ }^{20}$ This decision came years before Twombly and Iqbal, and, thus, the Court applied the lower pleading standard that prevailed prior to those cases. ${ }^{21}$ However, the Court noted that Plaintiffs went beyond what is required in claiming a per se violation, by identifying actual economic effects of the alleged conspiracy. ${ }^{22}$

\section{iii. Class Certification}

The Court certified the class on April 3, 2002. ${ }^{23}$ The Class was defined as: “(1) all persons (including corporations and other entities) holding a quota [under the Federal Tobacco Program] to grow flue-cured or burley tobacco in the United States at any time from February 1996 to the present and (2) all domestic producers of flue-cured or burley tobacco who sold such tobacco in the United States at any time from February 1996 to the present."24 Plaintiffs originally filed in federal court.

\section{iv. Settlements}

The litigation against RJR continued until April 22, 2004, the day of trial, when the parties reached the RJR Settlement. At a settlement conference before Judge Osteen on April 16, 2004, counsel for RJR indicated that RJR was reluctant to settle before trial because it perceived the MFN of the First Settlement to be "prohibitive" of its ability to reach agreeable terms. ${ }^{25}$

A total of 167,000 class members received \$200 million from the First Settlement, and a total of 178,000 class members received \$24 million from the RJR Settlement. The claimants of the RJR Settlement largely overlapped with the claimants of the First Settlement. ${ }^{26}$

Plaintiffs settled their case against all Defendants, except RJR, in May 2003 ("First Settlement”), ${ }^{27}$ and reached a separate settlement with RJR in April 2004 (“RJR Settlement”). ${ }^{28}$

${ }^{19}$ DeLoach v. Philip Morris Cos., 2001 WL 1301221 (M.D.N.C. July 24, 2001).

${ }^{20}$ Id. at *7-8.

${ }^{21} I$. at $* 5$.

${ }^{22}$ Id. at *7-8.

${ }^{23}$ Philip Morris Co., 206 F.R.D. 551 (M.D.N.C. 2002).

${ }^{24} 206$ F.R.D. at 552-53.

${ }^{25}$ Philip Morris, 391 F.3d at 555-56.

${ }^{26} 2006$ WL 5248981 (M.D.N.C. Oct. 5, 2006).

${ }^{27} 2003$ WL 22340726 (M.D.N.C., May 16, 2003) (First Settlement Agreement); See No. 1:00CV01235 (M.D.N.C. Oct 1, 2003) (First Settlement Approval).

${ }^{28} 2004$ WL 5508762 (M.D.N.C., Apr. 22, 2004) (RJR Settlement Agreement). See No. 1:00CV01235 (M.D.N.C. Mar. 31, 2005)(Final Settlement Approval). 
The Court approved the First Settlement on October 1, 2003, and the RJR Settlement on March 31, 2005. The settlements provided the class with $\$ 310$ million in cash, including attorneys' fees and expenses. $^{29}$

In December 2004, the Fourth Circuit resolved the issue regarding the effect of the RJR Settlement on the volume commitments under the First Settlement. ${ }^{30}$ Subsequently, the District Court approved the RJR Settlement on March 31, 2005. This concluded the litigation. The Court awarded attorney's fees after the First Settlement on December 19, 2003, and after the RJR Settlement on August 8, 2005. ${ }^{31}$

On February 28, 2005, pursuant to the First Settlement, the settling Defendants transferred the initial cash installment of $\$ 130$ million to a trust account of Howrey Simon, LLP ("Class Counsel”). ${ }^{32}$ Class Counsel completed the claim distribution to the class in 2006, and the distribution of the remaining funds to public land-grant universities in 2009 . $^{33}$

Class Counsel requested $\$ 175$ million to cover fees and costs after the First Settlement, and \$15 million to cover the same after the RJR Settlement. ${ }^{34}$ The Court found an award of \$84 million in attorneys' fees and expenses to be fair and reasonable. ${ }^{35}$ Class Counsel received an equivalent of $27 \%$ of Plaintiffs' total recovery.

\section{v. Repercussions}

As a result of Class Counsel's effort, Congress passed the Fair and Equitable Tobacco Reform Act of $2004,{ }^{36}$ which grants an additional $\$ 9.6$ billion to tobacco farmers as they transition to the free market for tobacco. ${ }^{37}$

Judge William L. Osteen, Sr. was appointed by President George H.W. Bush, a Republican, in $1991 .^{38}$ Judge Osteen, Sr. presided over the litigation until his retirement on Sept. 14, 2007. ${ }^{39}$ He wrote the Court's decisions on the motion to dismiss and the award of attorneys' fees and expenses.

\footnotetext{
${ }^{29}$ The First Settlement included \$200 million in cash, \$75.4 million in attorneys’ fees and expenses, and \$1.8 million for claims administration. First Settlement at $\$ \S 2.0-2.2 ; 2003$ U.S. Dist. LEXIS 23240, at *38-39. The RJR Settlement provided the Class with \$24.2 million in cash, and \$8.7 million for attorneys’ fees and expenses. RJR Settlement at § 2.1; No. 1:00CV01235 (M.D.N.C. Aug 4, 2005).

${ }^{30}$ Philip Morris, 391 F.3d 551 (4th Cir. 2004).

312003 U.S. Dist. LEXIS 23240 (M.D.N.C. Dec. 19, 2003), 2004-1 Trade Cas. (CCH) P74, 244; No. 00 CV01235 (M.D.N.C. Aug. 8, 2005).

322006 WL 5248981 (M.D.N.C. Oct. 5, 2006).

${ }^{33}$ See Class Counsels Reports on the Distribution of Settlement Funds, 2004 WL 5508764 (M.D.N.C., Aug. 27, 2004), 2005 WL 6010821 (M.D.N.C., Feb. 8, 2005), 005 WL 6010832 (M.D.N.C., Sep. 2, 2005), 2006 WL 5248981 (M.D.N.C., Oct. 5, 2006), 2006 WL 5248982 (M.D.N.C. Oct. 5, 2006).

${ }^{34} 2003$ U.S. Dist. LEXIS 23240, at *9; No. 00CV01235 (M.D.N.C. Aug. 8, 2005).

35 See 2003 U.S. Dist. LEXIS 23240, at *31, 38; See also No. 00CV01235 (M.D.N.C. Aug. 4, 2005).

${ }^{36}$ Pub. L. No. 108-357, §§ 601-643, 118 Stat. 1418, 1521-36 (2004).

${ }^{37}$ See No. 1:00CV01235 (M.D.N.C. Feb. 25, 2005)( Memorandum in Support of Plaintiffs' Motion for Final Approval of RJR Settlement); See also FSA-Tobacco, Tobacco Transition Payment Program, http://www.apfo.usda.gov/FSA/webapp?area=home\&subject=toba\&topic=landing (last visited Nov. 5, 2010). ${ }^{38}$ Federal Judiciary Center, http://www.fjc.gov/servlet/nGetInfo?jid=1817\&cid=126\&ctype=dc\&instate=nc $(($ last visited Nov. 11, 2010).

${ }^{39}$ When Judge Osteen, Sr. retired, the Court maintained jurisdiction over the claims distribution in this case. His son, William L. Osteen, Jr. filled his seat, and was assigned to this case on Oct. 12, 2007. Judge Osteen, Jr. was appointed by George W. Bush, a Republican, on Jan. 1, 2007. Federal Judiciary Center, http:/www.fjc.gov/servlet/nGetInfo?jid=3156\&cid=126\&ctype=dc\&instate=nc (Last visited Nov. 11, 2010).
} 
Judge Osteen had high praise for Class Counsel in his decision on attorney’s fees after the First Settlement. He stated that: "Plaintiffs' Co-Lead Counsel...faced the daunting task of litigating against an industry that is one of the most ardently protective of its rights and wellrepresented in the nation with no guarantee that their investments of time and effort would be repaid." 40 "This settlement was the first class action antitrust settlement (and the largest class action settlement of any kind) by these Defendants." 41 "[T]he fact there were no objections to the settlement and only 161 timely opt-outs testifies to the value of the settlement in the eyes of the class."42 "Moreover, Plaintiffs' Co-Lead Counsel reached this result without the benefit of assistance from numerous other law firms. In many similar cases, numerous law firms join the case by filing related actions that are eventually consolidated into a single case. The fact that no additional firms joined this case may show that the legal community thought this case against these defendants was untenable. It also reinforces the value of the settlement achieved for the class given that Plaintiffs' Co-Lead Counsel were not assisted by so great a number of additional lawyers." "43

There are no scholarly articles directly addressing the legal merits of this case. However, in the June 2010 issue of Oxford's Journal of Competition Law \& Economics, economist Andrew Hanssen argues that the alleged collusion and abuse of monopsony power in DeLoach, may be more properly viewed as a purchasing practice which developed as a means to "combat the fundamental problem that the quality of tobacco leaf is very costly to measure."44

\footnotetext{
${ }^{40} 2003$ U.S. Dist. LEXIS 23240, at *36.

${ }^{41} I d$. at *35-36.

${ }^{42} I$. at $* 36$.

${ }^{43}$ Id. at $* 37$.

${ }^{44}$ See Andrew Hanssen, Monopsony Abuse or Efficient Purchasing? Quality Measurement in the Tobacco Leaf Market, 6 J. Competition L. \& Econ. 443 (June 2010).
} 


\section{Tricor Antitrust Litigation ${ }^{1}$}

This case is notable because: (1) the plaintiffs received a total settlement of $\$ 315.7$ million; (2) the plaintiffs' attorneys were awarded \$110.8 million for fees, costs, and expenses they incurred (33 1/3\% plus costs); (3) state attorneys general independently brought suit against the defendants and received a total settlement of $\$ 22,500,000$; (4) for the state cases, the attorneys were awarded $\$ 5,940,634$ as fees and costs from the settlement fund.

\section{A. Factual Background}

Fenofibrate is a drug prescribed in the treatment of hypolipidemia and hypocholesterolemia. $^{2}$ The customary form of dosage for fenofibrate was to take three gelatin capsules daily, with each of the capsule containing $100 \mathrm{mg}$ of fenofibrate. ${ }^{3}$ Phillippe Reginault ("Reginault") began to research a way not only to create a single daily dosage of fenofibrate, but also to refine the effectiveness of the dosage form. Reginault's process called for the fenofibrate and a "solid surfactant" to be run through an air-jet mill, which produces very small granules of the drug-surfactant compound. ${ }^{4}$ The solid surfactant recommended for use is an alkali metal sulfate of lauryl alcohol, such as sodium lauryl-sulfate. ${ }^{5}$ The drug-surfactant compound is then mixed with water to create a gel, and then inserted into gelatin capsules. ${ }^{6}$ By creating a "comicronized" version of the drug, a daily single 200mg co-micronized dosage would have the same effectiveness as a single daily non-micronized 300mg gel-capsule dosage. ${ }^{7}$

After researching and developing the co-micronized fenofibrate capsules, Reginault filed for patent protection on January 19, 1989. ${ }^{8}$ On January 23, 1990, Patent No. 4,895,726 was issued to the assignee for the patent, Fournier Industrie et Sante' and Laboratories Fournier S.A. ("Fournier"), for Reginault's novel dosage of the drug fenofibrate. ${ }^{9}$ Fournier was chosen as the assignee because Reginault worked for Fournier as the director of pharmaceutical development at the time of the invention. ${ }^{10}$ Fournier approached Abbott Industries ("Abbott”) to market the co-micronized fenofibrate capsules in America. Abbott and Fournier received FDA approval for the capsules in 2000, ${ }^{11}$ and marketed the capsules throughout 2000 and 2001 under the name Tricor-A. ${ }^{12}$

Subsequent to the marketing of Tricor-A, Teva Pharmaceuticals USA, Inc. and Teva Pharmaceutical Industries, Ltd. (collectively “Teva”) and Impax Laboratories, Inc. (“Impax”) independently desired to develop generic brands of fenofibrate. In attempts to gain a license from the FDA to do so, both filed Abbreviated New Drug Applications (“ANDAs”) with the FDA. $^{13}$

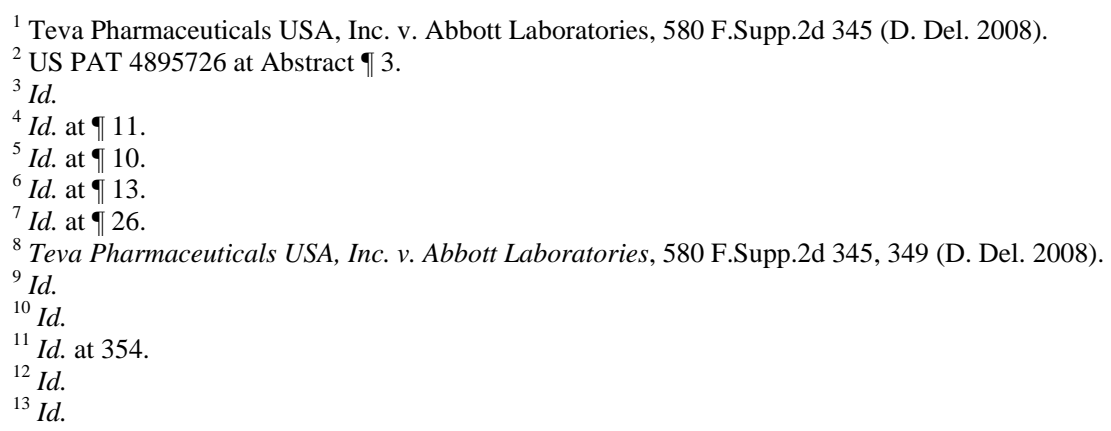




\section{B. Procedural Background}

Litigation under the ANDAs was initiated by Fournier and Abbott (collectively "defendants") in 2002. ${ }^{14}$ Defendants brought three lawsuits against Teva and Impax in the district court for the Northern District of Illinois for patent infringement, which were known as the "capsule litigation."15 Two of the suits resulted in consecutive stays to Teva's and Impax's FDA ANDA approval process. ${ }^{16}$ Teva successfully moved for summary judgment on a finding of non-infringement, a decision upheld on appeal by the Federal Circuit. ${ }^{17}$ During the appeal before the Federal Circuit, Teva received FDA approval, and began marketing their generic fenofibrate. $^{18}$

While the capsule litigation regarding Tricor-A was proceeding, in September, 2001, defendants began developing and marketing Tricor-B, which came in $160 \mathrm{mg}$ tablet strengths. ${ }^{19}$ Defendants began to solely market Tricor-B instead of Tricor-A, causing Tricor-A to be obsolete and Teva and Impax's drugs to lose generic insurance co-payment status. ${ }^{20}$ Upon Teva and Impax's attempt to file ANDAs for Tricor-B, defendants filed three complaints for patent infringement against them in district court for the District of Delaware, which were known as the "tablet litigation."21 Again, two successive stays to their ANDAs were imposed, delayed by defendants in order for them to receive patent protection for the patents they were claiming were infringed in the litigation. ${ }^{22}$

Defendants again implemented a "market switch" during the tablet litigation, converting their main drug prescribed from Tricor-B to Tricor-C, a new tablet that only differed in dosage strength from Tricor-B. ${ }^{23}$ Defendants were granted FDA approval to market Tricor-C in November $2004 .^{24}$

After the end of the separate actions involving Teva and Impax, two different classes formed to represent groups of plaintiffs. Parties filed claims in the District Court of Delaware, with the Honorable Sue L. Robinson presiding over both the Direct and Indirect Classes. ${ }^{25}$ Judge Robinson was appointed by the Republican President George H.W. Bush. ${ }^{26}$

The Direct Class was made up of plaintiffs who had purchased Tricor from Abbott. ${ }^{27}$ The Indirect Class consisted of business and individuals who purchased Tricor from a third

\footnotetext{
${ }^{14}$ Abbot Laboratories v. Teva Pharmaceutical Industries, Ltd., 2002 WL 34247098 (D. Del. 2002).

${ }^{15}$ Teva, 580 F. Supp.2d at 354.

${ }^{16}$ Id. at 355 .

${ }^{17} \mathrm{Id}$.

${ }^{18} \mathrm{Id}$.

${ }^{19} I d$.

${ }^{20} I d$.

${ }^{21} I d$.

${ }^{22} I d$.

${ }^{23} I d$.

${ }^{24} \mathrm{Id}$.

${ }^{25}$ In re Tricor Indirect Antitrust Litigation, C.A. No. 05-360, Order and Final Judgment Approving Settlement, 10/28/2009.

${ }^{26}$ http://en.wikipedia.org/wiki/Sue_Robinson

${ }^{27}$ The Direct Class named plaintiffs were as follows: Louisiana Wholesale Drug Company, Inc.; American Sales Company, Inc.; CVS Pharmacy, Inc.; Rite Aid Corporation; Rite Aid Headquarters Corporation; Meijer, Inc.; Meijer Distribution, Inc.; Rochester Drug Co-Operative, Inc.; Walgreen Co.; Eckerd Corporation; The Kroger Co.; Maxi Drug, Inc.
} 
party. ${ }^{28}$ Defendants Abbott and Fournier filed a motion to dismiss the suit, but the court denied the motion on May 26, 2006. ${ }^{29}$ In another attempt to dismiss the claims against them, defendants filed nine summary judgment motions on issues of infringement, best mode, enablement, and indefiniteness. $^{30}$ Six of the motions were denied, two were denied in part, and one based on infringement was partially granted. ${ }^{31}$ The result of the motions was to leave an antitrust claim pending, claiming that the defendants had (1) engaged in sham litigation with no basis or probable cause for alleging infringement and (2) committed inequitable conduct and/or Walker process fraud. $^{32}$ The District Court then granted summary judgment as to the claim regarding inequitable conduct and Walker process fraud. ${ }^{33}$ The court, however, denied summary judgment in relation to the claim of sham litigation based on lack of probable cause for asserting patent infringement, finding that an issue as to material facts still existed. ${ }^{34}$

\section{i. $\quad$ Class Certification}

On August 18, 2008, both the Direct and Indirect Classes were certified by the District Court. The Direct Class was defined as: "All persons or entities in the United State who purchased TRICOR ${ }^{\circledR}$ in any form directly from any of the defendants at any time during the period April 9, 2002 through the present. Excluded from the DP Class are defendants and their officers, directors, management, employees, subsidiaries, or affiliates, and all federal government entities." ${ }^{35}$ The Direct Class was certified during litigation. The Indirect Class was defined as: "All persons or entities throughout the United States and its territories who purchased, paid for and/or reimbursed for fenofibrate products, including TRICOR ${ }^{\circledR}$ tablets and TRICOR ${ }^{\circledR}$ capsules, intended for consumption by themselves, their families, or their members, employees, plan participants and beneficiaries or insureds during the period April 9, 2002 through such time in the future as the effects of defendants' illegal conduct, as alleged, have ceased. Excluded from the IP Class are all defendants and their respective subsidiaries and affiliates, all government entities (except for government-funded employee benefit funds), and all persons or entities that purchased fenofibrate products: (1) for purposes of resale, or (2) directly from any of the defendants."36 The Indirect class was certified during litigation.

\footnotetext{
${ }^{28}$ The Indirect Class named plaintiffs were as follows: PacifiCare Health Systems, Inc.; Allied Services Division Welfare Fund; Hector Valdes; Cindy Cronin; Diana Kim; Alberto Litter; Local 28 Sheet Metal Workers; Painters District Council No. 30 Health and Welfare Fund; Pennsylvania Employees Benefit Trust Fund; Philadelphia Federation of Teachers Health and Welfare Fund; Elain M. Pullman; Neil Perlmutter; Helena Perlmutter; Lula Ramsey; Charles M. Shain; Sandra Krone; Vista Healthplan, Inc.; and Ross Love.

${ }^{29}$ Teva, 580 F. Supp.2dat 359.

${ }^{30}$ Id. at 357 .

${ }^{31}$ Id.

${ }^{32} I d$. at 358.

${ }^{33} I d$.

${ }^{34} I d$.

${ }^{35}$ In Re Tricor Direct Purchaser Antitrust Litigation, C.A. No. 05-340, Order Granting Motion to Certify Class, $8 / 18 / 2008$

${ }^{36}$ In re Tricor Indirect Purchaser Antitrust Litigation, C.A. No. 05-360, Order Granting Motion for Class Certification, 8/18/2008.
} 


\section{ii. $\quad$ State Attorneys General Suits}

In addition to the two classes of plaintiffs, a collection of state attorneys general brought suits against the Class Defendants. ${ }^{37}$ The attorneys general brought claims under both $\S 1$ and $\S$ 2 of the Sherman Act, as well as antitrust statutes from some individual states. ${ }^{38}$ The original complaints were filed on March 18, 2008, after the individual plaintiffs for both classes had filed their complaints. $^{39}$ The attorneys general filed their First Amended Complaint on April 18, 2008. ${ }^{40}$ On August 18, 2008, the district court granted a motion to stay all state law antitrust claims of the Indirect Class Plaintiffs because of the certification of the Direct and Indirect Classes. ${ }^{41}$ As a consequence, the litigation brought by the States was also stayed. ${ }^{42}$ On motion by the States, the stay was lifted by court order on April 22, 2009. ${ }^{43}$ Prior to the settlement of the State's litigation, the State of Vermont and the State of Ohio stipulated to dismissal with prejudice of all their claims against Defendants. ${ }^{44}$ The litigation was stayed a second time on October 23, 2009, through joint stipulation between the parties involved due to an agreement in principle to settle. $^{45}$

\section{iii. Settlements}

The Direct Purchaser Plaintiff class $^{46}$ settled with the Class Defendants on January 9, $2009,{ }^{47}$ for a total of $\$ 250,000,000{ }^{48}$ The court approved the settlement on April 23, 2009. ${ }^{49}$

\footnotetext{
${ }^{37}$ The following states participated in the litigation: Florida, Arizona, Arkansas, California, Connecticut, District of Columbia, Idaho, Iowa, Kansas, Maine, Maryland, Massachusetts, Michigan, Minnesota, Missouri, Nevada, New York, North Carolina, Ohio, Oregon, Pennsylvania, South Carolina, Texas, Vermont, Washington, and West Virginia. State of Florida, et al. v. Abbott Laboratories, et al., C.A. No. 08-155, First Amended Complaint, 4/18/2008.

${ }^{38}$ Id.

${ }^{39}$ State of Florida, et al. v. Abbott Laboratories, et al., C.A. No. 08-155, Complaint, 3/18/2008.

${ }^{40}$ State of Florida, et al. v. Abbott Laboratories, et al., C.A. No. 08-155, First Amended Complaint, 4/18/2008.

${ }^{41}$ State of Florida, et al. v. Abbott Laboratories, et al., C.A. No. 08-155, Order Denying Motion to Consolidate and Staying State Actions, 8/18/2008.

${ }^{42} I d$.

43 State of Florida, et al. v. Abbott Laboratories, et al., C.A. No. 08-155, Order Lifting Stay, 4/22/2009.

${ }^{44}$ See State of Florida, et al. v. Abbott Laboratories, et al., C.A. No. 08-155, Stipulation of Dismissal With Prejudice for the State of Vermont, 8/10/2009. See also State of Florida, et al. v. Abbott Laboratories, et al., C.A. No. 08-155, Stipulation of Dismissal With Prejudice for the State of Ohio, 8/27/2009.

${ }^{45}$ State of Florida, et al. v. Abbott Laboratories, et al., C.A. No. 08-155, Stipulation and Proposed Order Staying the Litigation, 10/23/2009.

46 The Direct Purchaser settlement class was defined in the settlement agreement as: “The Direct Purchaser Class includes all person or entities in the United States who purchased TRICOR ${ }^{\circledR}$ in any form directly from Abbott Laboratories (“Abbott”), Fournier Industrie et Sante, or Laboratories Fournier S.A. ("Fournier”) (Abbott and Fournier collectively are "Defendants”) at any time during the period April 9, 2002 through August 18, 2008. Excluded from the Class are Defendants and their officers, directors, management, employees, subsidiaries, or affiliates, all federal government entities, and the following entities that opted out of the Class: Ahold a/k/a American Sales Corp., Albertson's Inc., CVS Pharmacy, Inc., CVS Corporation, Eckerd Corporation, Maxi Drug, Inc. d/b/a Brooks Pharmacy, Hy-Vee, Inc., Kroger Co., Rite aid Corporation, Rite Aid Headquarters Corporation, Safeway, Inc., Walgreen Co., State of Oregon (all government entities), State of Washington (all government entities), Maryland State Employee and Retiree Health and Welfare Benefits Program and the Maryland Pharmacy Program, Connecticut Department of Social Services, State of New York (all government entities), State of Texas Health and Human Services Commission, Commonwealth of Massachusetts Executive Office of Health and Human Services Office of Medicaid (MassHealth), Pennsylvania Department of Public Works and Department of Aging,
} 
The awards to each individual class member were distributed on a pro rata basis through the claims administrator, Epiq Systems, Inc. ${ }^{50}$ For attorney's fees, the court awarded from the settlement fund $\$ 83,333,333.33$ for fees to counsel for the Direct Class plaintiffs, and an additional $\$ 3,590,415.82$ as fees from the settlement fund to reimburse them for expenses incurred during the prosecution of the lawsuit, both being awarded on April 23, 2009.51

The Indirect Purchaser class ${ }^{52}$ settled with the Class Defendants on May 5, 2009, ${ }^{53}$ for a total amount of $\$ 65,700,000$, with $\$ 33,333,334$ allocated to the consumers and $\$ 32,366,666$ allocated to the Third Party Payors. ${ }^{54}$ The court approved the settlement on October 28, 2009. ${ }^{55}$ Each individual class member received a share of the settlement on a pro rata basis based upon reported purchase amounts. $^{56}$ For attorney's fees, on October 28, 2009, the court awarded $\$ 21,900,000$ to plaintiffs' counsel out of the settlement fund, and an additional $\$ 1,936,242.58$ for costs incurred while litigating the matter. ${ }^{57}$

Finally, the State attorneys general settled with the Class Defendants on December 31, $2009,^{58}$ for a total amount of $\$ 22,500,000 .^{59}$ The court approved the settlement between the parties on January 7, 2010. ${ }^{60}$ Each individual class member received a share of the settlement at the direction of the Attorney General for the State of Missouri. ${ }^{61}$ For attorney's fees, on December 31, 2009, the court awarded $\$ 5,940,634$ as fees and costs from the settlement fund. ${ }^{62}$

and Overman \& Stevenson Pharmacists.” In re Tricor Direct Antitrust Litigation, C.A. No. 05-340, Order and Final Judgment, 4/23/2009.

${ }^{47}$ In re Tricor Direct Antitrust Litigation, C.A. No. 05-340, Order and Final Judgment, 4/23/2009.

${ }^{48}$ In re Tricor Direct Antitrust Litigation, C.A. No. 05-340, Brief in Support of Motion for Preliminary Approval of Settlement, 1/6/2009.

${ }^{49}$ In re Tricor Direct Purchaser Antitrust Litigation, C.A. No. 05-340, Order and Final Judgment, 4/23/2009.

${ }^{50}$ Id..

${ }^{51} \mathrm{Id}$.

52 The Indirect Purchaser settlement class was defined in the settlement agreement as: “All persons or entities throughout the United States and its territories who purchased, paid for and/or reimbursed for fenofibrate products, including TriCor ${ }^{\circledR}$ tablets and TriCor ${ }^{\circledR}$ capsules, intended for consumption by themselves, their families, or their members, employees, plan participants, beneficiaries or insureds during the period April 9, 2002 through the date the Court issues an order preliminarily approving the settlement (the "Class Period”), excluding (a) Defendants and their respective subsidiaries and affiliates and (b) all government entities (except for government-funded employee benefit funds), and (c) all persons or entities that purchased fenofibrate products for purposes of resale or directly from any of the Defendants to the extent and solely to the extent of such purchases for purposes of resale or such direct purchases. Also excluded are PacifiCare Health Plan Adminsitrators, Inc. as well as separately-settling health plans ("SHPs") listed on Attachment A hereto.” In re Tricor Indirect Purchaser Antitrust Litigation, C.A. No. 05360, Order and Final Judgment Approving Settlement, 10/28/2009.

${ }^{53}$ Id.

${ }^{54}$ In re Indirect Purchaser Antitrust Litigation, C.A. No. 05-360, Brief in Support of Motion for Preliminary Approval of Settlement, 5/7/2009.

${ }^{55}$ In re Indirect Purchaser Antitrust Litigation, C.A. No. 05-360, Order and Final Judgment Approving Settlement, 10/28/2009.

${ }^{56} \mathrm{Id}$.

${ }^{57}$ Id.

${ }^{58}$ Florida v. Abbott Laboratories, C.A. No. 08-155, Stipulated Dismissal and Settlement Agreement, 1/7/2010.

${ }^{59}$ Id.

${ }^{60}$ Id.

${ }^{61}$ Id.

${ }^{62}$ Id. 


\section{Visa (United States v. Visa USA) ${ }^{1}$}

This lawsuit is notable because (1) in the aggregate Visa and MasterCard agreed to pay American Express and Discover \$6.813 billion; (2) American Express settled with Visa for \$2.25 billion and MasterCard for $\$ 1.8$ billion, a total settlement of $\$ 4.05$ billion and the largest antitrust settlement for a single company; (3) Discover entered into a single settlement with Visa (for \$1.9 billion) and MasterCard (for $\$ 862.5$ million) for a total of $\$ 2.7625$ billion.

\section{A. Factual Background}

There are four major systems (or networks) "that provide authorization and settlement services for U.S. credit and charge card transactions: Visa, MasterCard, American Express and Discover." 2 Visa and MasterCard operate as not-for-profit associations, whose members are financial institutions. ${ }^{3}$ Transaction fees (the merchant discount fee) are remitted to the merchant's acquiring bank, and the acquiring bank splits this fee with the original bank that issued the card. ${ }^{4}$ Conversely, American Express and Discover are both "for-profit companies that operate as 'closed loop,' vertically integrated systems." 5 The for-profit companies do not need to set interchange fees "because they are both the issuer and acquirer on all transactions and keep the full amount of the merchant discount fee."6

Because of the structural differences, the companies compete on two levels: first, the network services level, where the four companies compete based on individual interchange fees; and second, at the issuing level, where American Express and Discover compete to issue their cards with the thousands of Visa and MasterCard issuing banks. ${ }^{7}$ Stated another way, each credit card issuer negotiates with merchants on rates for card usages; larger networks allow consumers to use the card in more locations. Furthermore, competition among the credit card systems "plays a major role in determining the overall quality of the brand[,] . . . the creation of new products[,] and features and cost-saving increases."

Even if a card has a large network, to be effective it still needs consumers. The memberbanks issue cards with either the Visa or MasterCard network (the cards that the banks issue works with any merchant who has an agreement with the network). Since Discover and American Express were not connected to any member-banks, they directly solicit new members

\footnotetext{
${ }^{1} 163$ F. Supp. 2d 322, 331 (S.D.N.Y. 2001).

${ }^{2}$ United States v. Visa USA, et al., 163 F. Supp. 2d 322, 331 (S.D.N.Y. 2001), affd, 344 F.3d 229 (2d Cir. 2003), cert. denied, 543 U.S. 811 (2004) (hereinafter "Visa I").

${ }^{3} I d$. at 332. Visa has approximately 14,000 members while MasterCard has around 20,000 members. "MasterCard is open to any eligible financial institution," i.e., any "financial institution that is eligible for Federal Deposit Insurance Corporation deposit insurance" and the same is true for Visa. Id. "Visa members have the right to issue Visa cards and to acquire Visa transactions from merchants that accept Visa cards. In exchange, they must follow Visa's bylaws and operating regulations.” Id.

${ }^{4}$ Id.

${ }^{5}$ Id. at 333

${ }^{6}$ Id.

${ }^{7}$ Id.

${ }^{8} \mathrm{Id}$.
} 
by mail. ${ }^{9}$ Competition among issuers affects the prices that consumers pay and the variety of features they can obtain. ${ }^{10}$

For general credit card networks, “acquiring additional issuers leads to increased card issuance," 11 which is primarily how Visa and MasterCard increased their respective shares in the credit card markets. In 1991, Visa passed bylaw 2.10(e), which provided that "the membership of any member shall automatically terminate in the event it, or its parent, subsidiary or affiliate, issues, directly or indirectly, Discover Cards or American Express Cards, or any other card deemed competitive by the Board of Directors."12 MasterCard enforced a similar rule that was formally incorporated into the Competitive Programs Policy (CPP) in June 1996 providing: "With the exception of participation by members in Visa, which is essentially owned by the same member entities, members of MasterCard may not participate either as issuers or acquirers in competitive general purpose card programs."13

\section{B. Procedural Background}

\section{i. Department of Justice Action}

On October 7, 1998, the Department of Justice filed suit against Visa and MasterCard alleging that the companies violated the Sherman Act. The DOJ alleged that Visa and MasterCard conspired to restrain trade by: (1) "enacting rules permitting a member-owner of one to function as a director of the other;" (i.e., dual governance) and (2) "enacting and enforcing 'exclusionary rules,' which prohibit their member banks from issuing American Express . . . or Discover cards." 14 After a lengthy trial process (the bench trial lasted 34 days) the district court ruled against the DOJ on the dual governance issue and ruled in favor of the government on the second count for enacting and enforcing exclusionary rules. ${ }^{15}$ The court held that the Visa Bylaw and MasterCard CPP barring member-banks from issuing competing cards had an adverse effect on the market by "excluding American Express and Discover from offering network services to bank issuers, resulting in decreased network-level competition and fewer and less varied credit card products to the consumer." 16

Visa and MasterCard appealed arguing that the court erred in concluding "that their respective exclusionary rules violate[d] the Sherman Act."17 However, the Department of Justice did not appeal the district court's ruling on dual governance. ${ }^{18}$ The Second Circuit affirmed the district court ruling. ${ }^{19}$ Visa and MasterCard petitioned for certiorari; however, the Supreme Court denied the petition. ${ }^{20}$

9 "In 1999 alone, issuers sent out 2.9 billion direct mail solicitations to households in the United States, an average of 2.4 solicitations per month to each household.” Id. at 334.

${ }^{10} \mathrm{Id}$. at 333.

${ }^{11}$ Id. at 387.

${ }^{12} I d$. at 379 .

${ }^{13}$ Id. at 381.

${ }^{14}$ United States v. Visa U.S.A., Inc., 344 F.3d 229, 234 (2d Cir. 2003) (hereinafter “Visa II”)

${ }^{15}$ Visa I, 163 F. Supp. 2d at 379. Judge Barbara S. Jones presided. She was appointed by President Clinton. http://en.wikipedia.org/wiki/Barbara_S._Jones

${ }^{16}$ Visa I, 163 F. Supp. 2d at 379.

${ }^{17}$ Visa II, 344 F.3d at 234

${ }^{18} I d$. at 234 n.1.

${ }^{19} \mathrm{Id}$. at 234.

${ }^{20}$ Visa U.S.A., Inc. v. United States, 543 U.S. 811 (2004). 


\section{ii. Preliminary Proceedings}

Following the denial of certiorari by the Supreme Court, both American Express and Discover filed suit against Visa and MasterCard seeking treble damages. ${ }^{21}$ These cases involved "the same collusive conduct and exclusionary rules, committed by the same actors, motivated by the same anticompetitive purposes, and resulting in the same injuries.",22

Discover filed under Section 16 of the Clayton $\mathrm{Act}^{23}$ to prevent and restrain violations of Sections 1 and 2 of the Sherman Act, ${ }^{24}$ and for damages under Section 4 of the Clayton Act. ${ }^{25}$ The claims for relief included: attempt to monopolize; conspiracy to restrain trade in the general credit card industry; monopoly maintenance (against Visa); and conspiracy to monopolize. ${ }^{26}$ Discover claimed that Visa and MasterCard "adopted and predatorily enforced their anticompetitive rules to the detriment of consumers, competition and Discover." ${ }^{\text {,2 }}$ Discover alleged that Visa's and MasterCard's rules suppressed and limited Discover's share in the general credit card market to around 6\% since $1994 .^{28}$ In addition, the rules blocked Discover from participating in the general purpose debit card market altogether. ${ }^{29}$ Discover alleged that the anticompetitive rules harmed competition and reinforced Visa's and MasterCard's individual and collective dominance in the relevant markets. ${ }^{30}$

According to Discover, if not for the exclusionary rules, "Visa/MasterCard banks would have opted to issue over the Discover/NOVUS network . . . . .31 Discover claimed that many of the member-banks would have issued Discover cards because of the defendants' "lack of responsiveness to many of the banks' complaints. ${ }^{32}$ However, the member-banks did not contract with Discover because of the defendants' exclusionary rules, which resulted in the failure of these member-banks to become issuers on Discover's network. ${ }^{33}$ Discover claimed that Visa's and MasterCard's anticompetitive conduct suppressed Discover's growth in the industry. ${ }^{34}$ Indeed, between 1994 and 2005 Discover's market share declined from 6\% to 5.7\%.

\footnotetext{
${ }^{21}$ See Compl., Discover Fin. Servs. v. Visa U.S.A. Inc., et al., No. 04-CV-07844 (S.D.N.Y. Oct. 4, 2004); Compl., American Express Co. v. Visa U.S.A. Inc., et al., No. 04-CV-08967 (S.D.N.Y. Nov. 15, 2004).

${ }^{22}$ Compl. and Jury Demand, American Express, No. 04-CV-08967 at 94.

${ }^{23} 15$ U.S.C. § 26 (2006).

${ }^{24} 15$ U.S.C. $\S \S 1,2$ (2006).

2515 U.S.C. $\S 15$ (2006)

${ }^{26}$ See Second Amended Compl. Discover, No. 04-CV-07844 at ๆ甲 93-124, (S.D.N.Y. July 7, 2007). Discover’s complaint included five causes of action including two specific to Visa.

${ }^{27}$ Id. at 91.

${ }^{28} I d$.

${ }^{29}$ Id.

${ }^{30}$ Second Amended Compl. Discover, No. 04-CV-07844 at 13.

${ }^{31} \mathrm{Id}$. at 937.

${ }^{32} \mathrm{Id}$. at 9 38. Discover provided that many important banks wanted more flexibility and opportunity to differentiate their products from competing banks. Some banks wanted to emphasize their own branding over their affiliated network's branding. Id. Citibank publicly "expressed dissatisfaction over the subordination of their individual promotion strategies to the brand and advertising of Visa and MasterCard.” Id. The complaint goes into additional detail over other member-bank testimony and memoranda that show that the rules prevented member-banks from issuing Discover cards. See e.g., ๆๆ 42, 43.

${ }^{33}$ Id. at $₫ 40$

${ }^{34} \mathrm{Id}$. at 953.

${ }^{35}$ Id.
} 
Additionally, Discover alleged that absent Visa's and MasterCard's rules, the company would have enhanced its profitability. ${ }^{36}$

American Express filed similar charges under the Sherman Act and the Clayton Act alleging: intra-association conspiracies to restrain trade as well as inter-association conspiracies between Visa, MasterCard and member banks; single conspiracy to monopolize; and conspiracy to unreasonably restrain trade. ${ }^{37}$ American Express alleged that despite its "vigorous efforts during the past decade to reach issuing arrangements with Visa and MasterCard member banks . . . by the end of 2003, no United States bank had been willing to give up its membership in the Visa U.S.A. and MasterCard networks in order to issue Amex or Discover cards." 38 American Express further alleged that Visa's and MasterCard's

anticompetitive boycott of American Express . . . foreclosed American Express from a 'huge portion' of the network services market[ ]; restricted the output of American Express cards in the United States[ ]; restrained American Express' transaction volume, merchant acceptance levels, competitive vitality, and market share[ ]; and hampered American Express' ability to develop and market new card features and network capabilities[ ].

Id. at II 2; Visa I, 344 F.3d at [382]; [329, 379, 387]; [329, 379, 382]; and [329] (Internal citations omitted). ${ }^{39}$ American Express indicated that Visa's and MasterCard's anticompetitive conduct caused American Express to lose significant sources of profit in the United States. ${ }^{40}$

\footnotetext{
${ }^{36}$ Id. at 9 92. Specifically, the company claimed its profits would have increased through:

a. a substantially increased purchase volume of Discover transactions;

b. a substantially increased share of the credit card transaction market;

c. substantial entry into the debit card market via issuance of Discover debit cards by third-parties;

d. increased card issuance of Discover credit cards via third-party issuance;

e. expanded merchant acceptance of Discover;

f. increased positive, network externalities;

g. a greater number of transactions being completed at merchants that exclusively accept Discover;

h. enhanced performance of Discover Cards, including increased balances and higher cardholder activation rates;

i. greater Discover network margins on Discover transactions;

j. greater margins on transactions completed with cards issued by Discover;

k. card portfolio acquisitions;

l. new card products; and

m. increased economies of scale.

${ }^{37}$ Compl. and Jury Demand, American Express, No. 04-CV-08967 at ๆף 127-165. American Express’ complaint, like Discover's, included five counts against Visa, MasterCard and the member-banks.

${ }^{38}$ Id. at If 118 quoting Visa II, 344 F.3d at 237 (internal quotations omitted). One effort American Express undertook to entice member-banks to issue American Express cards was offering substantial incentive packages to the first bank that would break rank. Id. According to American Express, "[e]ven the banks that had expressed their own financial interest in issuing American Express cards - and objected to MasterCard's exclusionary rule - had refused to issue American Express cards.” Id. at 1119.

${ }^{39}$ Brackets indicate respective internal citations removed from quoted language.

40 See id. 1 125, these sources included:

a. Lost profits from lost merchant discount revenues on bank-issued general purpose cards;

b. Lost profits from lost merchant discount revenues on existing American Express cards as a result of decreased merchant acceptance;

c. Lost profits from decreased American Express card issuance as a result of decreased merchant acceptance;

d. Lost other merchant revenues and fees from decreased merchant acceptance;

e. Lost network profits and debit card transactions;
} 


\section{iii. Settlement-American Express}

Visa and MasterCard first settled with American Express. On June 24, 2008, MasterCard agreed to pay American Express $\$ 1.8$ billion. $^{41}$ Under the settlement agreement, MasterCard would make 12 quarterly payments of $\$ 150$ million to American Express beginning on September 15, 2008. ${ }^{42}$ On October 1, 2008, Visa announced that it had settled with American Express for $\$ 2.25$ billion. $^{43}$ Under the terms of the Visa agreement, Visa agreed to make payments consisting of: (i) $\$ 1.13$ billion, which was paid to the Company in the first quarter of 2008 and (ii) 16 additional quarterly payments of up to $\$ 70$ million per quarter commencing with quarter ending March 31, 2008. ${ }^{44}$

\section{iv. Settlement-Discover}

Discover reached an agreement in principle with Visa and MasterCard on October 13, 2008, and issued the settlement on October $27 .{ }^{45}$ Together, the companies settled for an amount equal to $\$ 2.7625$ billion. ${ }^{46}$ Visa created a settlement fund to pay the approximately $\$ 1.9$ billion that it agreed to pay to Discover. ${ }^{47}$ Under the agreement, Visa made four payments to Discover. The amount of the first three payments is equal to $5 \%$ of the Discover Financial Services Volume, while the last payment is $21 \%$ (to maximum of around $\$ 470$ million each quarter). ${ }^{48}$ Discover "met all financial performance measures to which [the company was] subject under the settlement agreement and, as a result, [Discover] received the maximum amount of $\$ 1.9$ billion, plus interest, in four quarterly payments from Visa in fiscal 2009."49 In contrast, MasterCard agreed to pay Discover in one lump sum of $\$ 862.5$ million before November 14, 2008, which the company received in the fourth quarter of $2008 .^{50}$

f. Lost profits from portfolio acquisitions;

g. Lost profits from lost fees and ancillary revenues from issuing banks; and

h. Lost economies of scale.

${ }^{41}$ Kirstim Maguire, Amex v. Visa USA et al., Corporate Counsel: DeALs \& SuITS, Vol. 15, Iss. 10, pg. 46, Oct. 1, 2008.

${ }^{42}$ American Express Exhibit 10.2, Form 10-Q filed Aug. 1, 2008, Release and Settlement Agreement, executed between American Express and MasterCard Inc. at 2-3 (June 24, 2008).

${ }^{43}$ Maguire, supra note 40.

${ }^{44}$ Visa U.S.A. Form S-1 filed Dec. 21, 2007, Release and Settlement Agreement, executed between American Express and Visa U.S.A. at 3 (Nov. 7, 2007).

${ }^{45}$ Discover Financial Services, LLC, Form 10-K for fiscal year 2008 at 38 (filed Jan. 28, 2009) available at http://www.sec.gov/Archives/ edgar/data/1393612/ 000119312509013205/d10k.htm.

${ }^{46} \mathrm{Id}$.

${ }^{47}$ American Express Exhibit 10.1, Form 10-Q filed Nov. 4, 2008, Release and Settlement Agreement, executed between Discover Financial Services, Visa USA Incorporated, and MasterCard Incorporated at 2 (Oct. 27, 2008) available at http://www.sec.gov/Archives/edgar/data/1393612/000118143108058430/rrd221617_26255.htm. Visa agreed to pay American Express \$1,887,500,000.

${ }^{48} I d$. at 4. For a schedule of the payments that Visa and Discover agreed to see id. at 8.

\begin{tabular}{|c|c|c|c|}
\hline Payment Date & Maximum Payment & Performance Period & Target (\% of DFS Volume) \\
\hline $12 / 15 / 2008$ & $471,875,000$ & $12 / 1 / 2008-2 / 28 / 2009$ & $5 \%$ \\
\hline $3 / 13 / 2009$ & $471,875,000$ & $3 / 1 / 2009-5 / 31 / 2009$ & $5 \%$ \\
\hline $6 / 15 / 2009$ & $471,875,000$ & $6 / 1 / 2009-8 / 31 / 2009$ & $5 \%$ \\
\hline $9 / 28 / 2009$ & $471,875,000$ & $9 / 1 / 2009-9 / 21 / 2009$ & $21 \%$ \\
\hline
\end{tabular}

${ }^{49}$ Discover, Form 10-K for fiscal year 2009 at 39 (filed Jan. 28, 2010) available at http://www.sec.gov/Archives/ edgar/data/1393612/000119312510014549/0001193125-10-014549-index.htm.

${ }^{50}$ Discover, Form 10-K for fiscal year 2008 at 38. 
Following the settlement with MasterCard and Visa, Discover and Morgan Stanley began litigating on the proper distribution of the settlement funds between the two companies. ${ }^{51}$ During the lawsuit, the two companies split and entered into an agreement to share the proceeds of the settlement between the two. ${ }^{52}$ On February 11, 2010, the parties entered into an agreement to share the proceeds of the settlement, the terms of which were confidential. ${ }^{53}$

\footnotetext{
${ }^{51}$ See Morgan Stanley v. Discover Financial Services, No. 08/603017 (N.Y. Sup. Ct. filed Oct. 21, 2008). The action was commenced in the Commercial Division of the Supreme Court of the State of New York, County of New York. Morgan Stanley sought a declaration that Morgan Stanley did not breach the Special Dividend Agreement, did not interfere with any of [Discover's] existing or prospective agreements for resolution of the antitrust case against Visa and MasterCard and that Morgan Stanley is entitled to receive a portion of the settlement proceeds as set forth in the Special Dividend Agreement.” Discover, Form 10-K for fiscal year 2008 at 38. Discover's response, filed November 18, 2008 includes "counterclaims against Morgan Stanley for interference with our efforts to resolve the antitrust lawsuit against Visa and MasterCard and willful and material breach of the Special Dividend Agreement, which expressly provided that we would have sole control over the investigation, prosecution and resolution of the antitrust lawsuit.” Id.

${ }^{52}$ See American Express Exhibit 10.2 Form 10-Q filed Nov. 4, 2008, Agreement, Executed between Morgan Stanley, Visa and Mastercard (Oct. 27, 2008).

${ }^{53}$ Settlement Agreement and Mutual Release, executed between Morgan Stanley and Discover Financial Services (Feb. 11, 2010) available at http://www.sec.gov/Archives/edgar/data/1393612/000119312510029585/dex101.htm.
} 


\section{Warfarin Sodium Antitrust Litigation (Warfarin Sodium II) ${ }^{1}$}

This case is notable because: (1) the plaintiffs received a total in damages of $\$ 44.5$ million; (2) the plaintiffs' attorneys were awarded $\$ 10$ million in fees and $\$ 832,382.84$ in costs (overall 24\%); (3) the case confirmed that indirect purchasers-in particular insurers and fixed co-pay consumers - have standing for certification as part of a class claiming under antitrust and consumer protection laws; (4) the case involved claims from all fifty states; and (5) the action was initiated entirely by plaintiffs' counsel (it was not a tag-along case).

\section{A. Factual Background}

DuPont patented Coumadin in the 1940s. Although the patent expired in 1962, DuPont remained the dominant manufacturer of warfarin sodium. ${ }^{2}$ In 1998 and 1999, DuPont recorded sales of warfarin sodium reaching approximately \$550 million and \$464 million, respectively. ${ }^{3}$ Having gained approval from the Food and Drug Administration, Barr began manufacturing and marketing a generic form of warfarin sodium in 1997. ${ }^{4}$ The plaintiffs alleged that before and after Barr introduced its generic warfarin sodium, DuPont "published false and misleading statements concerning the bioequivalence, therapeutic safety, and efficacy of generic warfarin sodium." ${ }^{5}$ Examples of the alleged anticompetitive conduct included adding warnings about generic substitutes to DuPont's promotional computer program used by physicians monitoring patients on Coumadin, ${ }^{6}$ circulating a slide presentation for health care professionals warning against the use of generic warfarin sodium, ${ }^{7}$ and undertaking a publicity campaign claiming that the generic alternatives to Coumadin were less safe. ${ }^{8}$ Plaintiffs claimed that DuPont's campaign of misrepresentation was so effective that it stunted market penetration by Barr's generic. ${ }^{9}$ Plaintiffs submitted evidence that while $40-70 \%$ of prescriptions available from different manufacturers are filled with cheaper generics within one year of generic availability, DuPont still retained $75 \%$ of the market one year after Barr introduced its generic version of sodium warfarin and $67 \%$ of the market at the time of suit. ${ }^{10}$

\section{B. Procedural Background}

The main actions in the case were: In re: Warfarin Sodium Antitrust Litig., C.A. No. MDL 98-1232-SLR, 1998 WL 883469 (D. Del. Dec. 7, 1998) (the defendant's motion to dismiss

\footnotetext{
1391 F.3d 516 (3d Cir. 2004)

${ }^{2}$ Warfarin Sodium II, 391 F.3d 516, 523 (3d Cir. 2004).

${ }^{3}$ Id.

${ }^{4}$ Id.

${ }^{5}$ Id.

${ }^{6}$ Id.

${ }^{7}$ Id.

${ }^{8}$ DuPont's campaign allegedly included advice that those taking the generic alternative should receive additional blood tests because Barr's generic drug had less strict content uniformity standards. The same press release also accused Barr of focusing on production of a cheaper product to save money while DuPont's emphasis was instead on patient safety. See 3D Cir. Affirms DuPont's \$44.5 Million Coumadin Settlement in 12 NO. 9 ANDREWS HEALTH L. LITIG. REP. at 11 (2005).

${ }^{9}$ Warfarin Sodium II, 391 F.3d 516, 523 (3d Cir. 2004).

${ }^{10}$ Id.
} 
- granted in part); ${ }^{11}$ In re Warfarin Sodium Antitrust Litig., 214 F.3d 395 (3d Cir. 2000) (class plaintiffs' appeal - reversed dismissal and remanded); ${ }^{12}$ In re Warfarin Sodium Antitrust Litig., 212 F.R.D. 231 (D. Del. Aug. 30, 2002) (class plaintiffs' motion to certify the class, approve settlement and award attorney's fees - granted); ${ }^{13}$ and In re Warfarin Sodium Antitrust Litig., 391 F.3d 516 (3d Cir. 2004) (appeal by class plaintiff objectors - affirmed). ${ }^{14}$

On December 8, 2004, the United States Court of Appeals for the Third Circuit rejected challenges by consumer objectors to the certification of a settlement class including out-ofpocket consumers, fixed co-pay consumers and Third Party Payors (TPPs) claiming injunctive relief against DuPont Pharmaceuticals Co.. ${ }^{15}$ This decision brought an end to seven years of litigation. ${ }^{16}$ The plaintiffs had filed a consolidated complaint in the District Court for the District of Delaware on behalf of similarly situated consumers alleging that DuPont had engaged in anticompetitive behaviour and disseminated false and misleading information about a lowerpriced, generic competitor product to its brand-name anticoagulant drug Coumadin, ${ }^{17}$ causing them to purchase the higher-priced Coumadin instead of the generic drug (produced by Barr Laboratories, Inc. (Barr)). ${ }^{18}$

The class plaintiffs alleged a violation of section 2 of the Sherman Act under the rule of reason.

The litigation in this case terminated in 2004 when the United States Court of Appeals for the Third Circuit affirmed the settlement.

No foreign firms were involved.

There is no reason to believe that the case lacked merit, although it is worth noting that a District Judge in Florida later queried the standing of insurers in private antitrust cases. ${ }^{19}$

This action was initiated by the plaintiffs - it was not a tag-along action to a government investigation. The full chronology is as follows. ${ }^{20}$

In December 1997, two consumer class actions, Kusnerik v. DuPont Merck Pharmaceutical Company, C.A. No. 97-659-SLR, and Altman v. DuPont Merck Pharmaceutical Company, C.A. No. 97-670-SLR, were filed in District Court of Delaware. Also, Kruse v. DuPont Merck Pharmaceutical Company, No. 97 CH 15799, Illinois Circuit Court, Cook County action was filed suit on behalf of a nationwide Coumadin consumer class, alleging violations of the Illinois Consumer Fraud Act and similar statutes in other states. Newman v. DuPont Merck

\footnotetext{
${ }^{11}$ Other identifying information: this case consolidated five actions (plaintiff: Barr, class plaintiffs: Kusnerik, Altman, Tischler and Steckel); Not Reported in F.Supp.2d, 1998 WL 883469 (D.Del.), 1999-1 Trade Cases P $72,457$.

12 Other identifying information: argued March 24, 2000, filed May 30, 2000; 2000-1 Trade Cases P 72,932, 46 Fed.R.Serv.3d 1010, 53 Fed. R. Evid. Serv. 1394, No. 99-5034.

${ }^{13}$ Other identifying information: 2002-2 Trade Cases P 73,791, No. MDL 98-1232-SLR.

${ }^{14}$ Other identifying information: argued Oct. 29, 2003, filed Dec. 8, 2004; 2004-2 Trade Cases P 74,632, Nos. 023603, 02-3755, 02-3757, 02-3758.

${ }^{15}$ In re Warfarin Sodium Antitrust Litigation (Warfarin Sodium II), 391 F.3d 516 (3d Cir. 2004).

16 The first class actions were filed in December 1997. See Kusnerik v. DuPont Merck Pharmaceutical Company, C.A. No. 97-659-SLR; Altman v. DuPont Merck Pharmaceutical Company, C.A. No. 97-670-SLR; Kruse v. DuPont Merck Pharmaceutical Company, No. 97 CH 15799, Illinois Circuit Court, Cook County; and Newman v. DuPont Merck Pharmaceutical Company, No. 788358, California Superior Court, Orange County.

17 Known generically as warfarin sodium and used by more than two million Americans to treat blood-clot disorders. See Warfarin Sodium II, 391 F.3d 516, 523 (3d Cir. 2004).

${ }^{18} \mathrm{Id}$. at 521.

${ }^{19}$ The standing of insurers was later queried in South East Laborers Health and Welfare Fund v. Bayer Corporation, 655 F.Supp.2d 1270, 1287 (ct? yr?).

${ }^{20}$ Details from In re Warfarin Sodium Antitrust Litigation, 212 F.R.D. 231, 237 (ct? yr?).
} 
Pharmaceutical Company, No. 788358, California Superior Court, Orange County, was filed as a multistate class action under state antitrust and consumer protection laws. In February, 1998, the court consolidated the Kusnerik and Altman actions under the caption In re Warfarin Sodium Antitrust Litigation, C.A. No. 97-659-SLR. (D.I. 237 at ๆ 6).

In the California trial court, plaintiffs successfully defended against defendant's motion to strike the complaint as a so-called "SLAPP suit” (Strategic Lawsuit Against Public Participation) and against a demurrer (equivalent to a motion to dismiss). Defendant appealed the SLAPP suit decision to the California Supreme Court; eventually the trial court decision was vacated and the issue was remanded to the trial court for further consideration. Defendant also sought stay or dismissal of the Newman action on the basis of a settlement in another state-wide antitrust class action which defendant claimed estopped the Newman action. After a hearing, the motion was denied.

In January 1998, another consumer class action was filed in the Southern District of Florida, Tischler v. DuPont Merck Pharmaceutical Company, C.A. No. 1:98-178. Plaintiffs in Tischler sought damages and injunctive relief under federal antitrust law, the Florida Deceptive and Unfair Trade Practices Act, and other state consumer protection laws.

In Febraury 1998, Shirley Ricks Freeman, Walter R. Goldstein and Andrew D. Baugus v. DuPont Merck Pharmaceutical Company, CV-98-58, Circuit Court of Lauderdale County, Alabama, was filed as a class action on behalf of Alabama consumers of Coumadin, pursuant to Alabama antitrust statutes. Defendant filed a motion for summary judgment alleging its acts fell outside the reach of Alabama antitrust statutes, which were wholly limited to intrastate commerce. The court granted defendant's motion, and the Supreme Court of Alabama affirmed the decision on appeal. Also, Plaintiff Barr Laboratories, Inc. filed suit in the Southern District of New York.

In March 1998, a fourth consumer class action, Steckel v. DuPont Merck Pharmaceutical Company, C.A. NO. 98-697, was filed in the Western District of Pennsylvania. The Steckel plaintiffs alleged violations of federal antitrust law and sought damages and injunctive relief.

In April 1998, Ambler v. DuPont Merck Pharmaceutical Co., No. BC189002, California Superior Court, Los Angeles County, was filed as a multistate class action alleging violations of state antitrust and consumer protection laws, as well as common law claims for fraud and deceit, negligent misrepresentation, and negligence. Brahm v. E.I. duPont de Nemours \& Co., Merck \& Co., and the DuPont Merck Pharmaceutical Co., No. 719668, California Superior Court, San Diego County was also filed at this time, on behalf of consumers in 13 jurisdictions, including California.

The Brahm and Ambler plaintiffs jointly petitioned the Judicial Council of the State of California to coordinate the Brahm, Ambler, and Newman actions, and the petition was granted after a hearing on the petition. Defendant filed a motion to strike the Brahm complaint as a SLAPP suit and, after briefing and argument, the complaint was dismissed.

In February 1998, Wilkinson v. E.I. duPont de Nemours \& Co., Merck \& Co., DuPont Merck Pharmaceutical Co., C.A. No. 3:98-440, Chancery Court of the State of Tennessee, 20th District, Davidson County was filed as a class action suit in Tennessee state court alleging violation of the Tennessee Consumer Protection Act and similar consumer protection statutes in 45 other states. Defendant removed the action to federal court and sought its transfer to the District of Delaware, but the Tennessee district court remanded it to state court. Defendant subsequently filed a motion to dismiss, which was denied with the exception of one count that was dismissed. Plaintiffs filed a motion for class certification and, after extensive discovery and 
oral argument before the court, the motion was denied. Plaintiffs filed an amended complaint alleging violations of the antitrust laws of sixteen jurisdictions as well as the Tennessee Consumer Protection Act. In a related action in the District of Columbia, the target of a document and deposition subpoena served by the Wilkinson plaintiffs filed a motion for a protective order, seeking to quash or modify the deposition subpoena. The court denied the motion, and the movant appealed.

In June 1998, plaintiffs filed a joint motion for class certification to certify a nationwide class of Coumadin indirect purchasers and to appoint class counsel.

In December 1998, the court granted defendant's motion to dismiss the Kusnerik, Altman, Tischler, and Steckel actions. But in March of 2000, on appeal, the Third Circuit reversed and remanded the court's decision with respect to injunctive relief, finding the consumer plaintiffs had standing under federal antitrust law. (214 F.3d 395, 2000-1 Trade Cases P 72,932, 46 Fed.R.Serv.3d 1010, 53 Fed. R. Evid. Serv. 1394)

Following remand of the Kusnerik, Altman, Tischler, and Steckel actions, several additional class actions were filed in this court and other federal courts by TPP plaintiffs and by a state Medicaid agency.

December 1998, settlement negotiations in federal actions began. Negotiations lasted for one year.

In July of 2000, the District Court entered the case management order and consolidated the Tischler, Steckel, Arkansas Carpenters, and United Wisconsin actions with the previously consolidated Kusnerik and Altman actions. The Louisiana Blue Cross action was added after its transfer to the same court. (Civ. No. 01-124, D.I.7)

In May of 2000, Alabama entered the fray with the filing of a complaint against defendant in the Southern District of Alabama, Southern Division. Alabama Medicaid Agency et al. v. DuPont Pharmaceutical, Inc. et al., C.A. No. 00-0420-BH-L. Also, in United Wisconsin Services, Inc. v. DuPont Pharmaceutical Company, C.A. No. 00-979-SLR, plaintiffs asserted claims based on federal antitrust law and state deceptive acts and practices and consumer protection laws on behalf of a nationwide class of TPPs.

In March of 2000, Louisiana entered on behalf of a nationwide class of TPPs. Louisiana Health Svcs. and Indemnity Company v. DuPont Pharmaceuticals, Inc., C.A. No. 00CV538C-Z. The action alleged unlawful and anticompetitive acts by defendant in violation of, among other things, the Clayton Act, the Robinson-Patman Act, and the Lanham Act. The action was transferred to the District Court as a tag-along action pursuant to the earlier MDL order.

In July 2000, Dean Health Plan, Inc. v. DuPont Merck Pharmaceutical Co., Case No. 00CV2357, State of Wisconsin, Dane County was filed. Dean Health Plan health maintenance organization filed a class action on behalf of consumers or entities who had purchased Coumadin not for resale, alleging violation of Wisconsin antitrust statutes.

In August and December, a separate action was filed in the District Court on behalf of a nationwide class of TPPs alleging violations of federal and state antitrust laws as well as state consumer protection laws. Arkansas Carpenters' Health \& Welfare Fund et al. v. DuPont Pharmaceutical Company, C.A. No. 00-1035-SLR and Krausman v. DuPont Pharmaceuticals Company, Index No. 49030/00, New York State Supreme Court, New York County was filed as a class action on behalf of consumer purchasers of Coumadin under the New York antitrust and consumer protection statutes.

In February 2001, a consolidated class action was filed. 


\section{i. Class Certification}

The class was certified as: "All consumers or Third Party Payors in the United States who purchased and/or paid all or part of the purchase price of Coumadin dispensed pursuant to prescriptions in the United States during the period March 1, 1997 through and including August 1, 2001 (“Class Period").” Excluded from the Class are Defendant and any of its officers and directors and any governmental entity. ““'Third Party Payor” shall mean any non-governmental entity that is (i) a party to a contract, issuer of a policy, or sponsor of a plan, which contract, policy or plan provides prescription drug coverage to natural persons, and is also (ii) at risk, pursuant to such contract, policy or plan, to provide prescription drug benefits or to pay or reimburse all or part of the cost of prescription drugs dispensed to natural persons covered by such contract policy or plan.,21

Several individual consumers and TPPs challenged the class certification on the grounds that the commonality and predominance requirements of Rule 23 of the Federal Rules of Civil Procedure were not satisfied because of variations in the claims and injuries of the plaintiffs under the 50 state laws. ${ }^{22}$ The appellants took issue in particular with the inclusion in the plaintiff class of fixed co-pay consumers, on the grounds that they paid the same amount regardless of whether they used Coumadin or the generic equivalent, and the inclusion of TPPs, such as insurers and health plan providers, on the grounds that they were not directly harmed. ${ }^{23}$

\section{ii. Settlement}

Settlement negotiations between DuPont and the class plaintiffs began in March 2000 and lasted for more than one year. ${ }^{24}$ The motion for final approval of the settlement, certification of the settlement class and award of attorney's fees was granted in August 2002. ${ }^{25}$ The class had originally sought both injunctive relief under section 16 of the Clayton Act and treble damages under section 4 of the Clayton Act, but this claim was initially dismissed by the district court for failure to state a claim upon which relief can be granted. ${ }^{26}$ The Third Circuit reversed and remanded the lower court's decision with respect to injunctive relief, finding that the consumer plaintiffs had standing under federal antitrust law. ${ }^{27}$

Settlement negotiations ended with all parties entering into a Stipulation of Settlement and Compromise in July 2001, after the consolidated class action is filed in March 2001.

The Third Circuit affirmed the settlement and certification of the settlement class. The court ruled that the class certification was appropriate because DuPont's liability did not depend on the conduct of individual class members. ${ }^{28}$ DuPont's allegedly deceptive conduct arose from "a broad-based, national campaign conducted by and directed from corporate headquarters, and individual reliance on the misrepresentations was irrelevant to liability". ${ }^{29}$ The plaintiffs suffered only economic injury (as opposed to physical harm from the drug) therefore the injuries

${ }^{21}$ Warfarin Sodium II, 391 F.3d 516, 525 (3d Cir. 2004).

${ }^{22}$ Warfarin Sodium II, 391 F.3d 516, 527 (3d Cir. 2004).

${ }^{23} \mathrm{Id}$.

${ }^{24}$ Warfarin Sodium II, 391 F.3d 516, 525 (3d Cir. 2004).

${ }^{25}$ In re Warfarin Sodium Antitrust Litigation, 212 F.R.D. 231, 2002-2 Trade Cases P 73,791.

${ }^{26}$ In re Warfarin Sodium Antitrust Litigation, Not Reported in F.Supp.2d, 1998 WL 883469 (D.Del.), 1999-1 Trade Cases P 72,457.

${ }^{27}$ In re Warfarin Sodium Antitrust Litigation, 214 F.3d 395 (3d Cir. 2000).

${ }^{28} I d$. at 528.

${ }^{29} \mathrm{Id}$. 
suffered by the TPPs were not derivative. ${ }^{30}$ The antitrust injury sustained by the TPPs was direct and independent - the TPPs had paid more for the brand-name drug, as had the individual consumers. The court also emphasized that the class was being approved for settlement purposes, rather than for litigation, therefore the variations in the 50 state laws under which the consumers were claiming would not create difficulties in case management in the future. ${ }^{31}$

In March 2001, all parties entered into Stipulation of Settlement and Compromise. In July 2001, the court granted a preliminary approval of the settlement and conditionally certified the class. In August 2001, there was a motion for final approval of settlement, certification of settlement class and award of attorney's fees granted. (212 F.R.D. 231, 2002-2 Trade Cases P 73,791)

On December 8, 2004, the Court of Appeals, Third Circuit affirmed approval of the settlement (391 F.3d 516, 2004-2 Trade Cases P 74,632). The settlement class consisted of individual consumers and TPPS, all indirect purchasers. Prior to approval of the settlement by the District Court, DuPont had already placed \$44.5 million in escrow, accruing interest for the settlement class. The "recognized loss" for each class member was to be total payments made for Coumadin (less the amounts received for reimbursements, discounts or rebates) multiplied by $15 \% .^{32} 18 \%$ of the Net Settlement Fund was to be set aside as a "Preferential Fund" out of which the recognized losses of consumers would be paid. ${ }^{33}$ If the total recognized losses of consumers were not fully satisfied out of the Preferential Fund, the unsatisfied amounts were to be paid from the remainder of the Net Settlement Fund on a pro-rata basis with TPP claimants. ${ }^{34}$ If the recognized losses of consumers were fully satisfied from the Preferential Fund and money remained in that fund, the unexpended portion was to be added to the Net Settlement Fund for payment of the recognized losses of TPPs. ${ }^{35}$ In the event, claims by consumer class members totalled $\$ 4.3$ million by the claim deadline - well within the allocated $18 \%$ Preferential Fund. ${ }^{36}$

The overcharge was not computed or found by a judge or jury. The plaintiffs' expert estimated the supra-competitive price to be $2.5 \%$ more than it would have been resulting in recognized loss to each class member of 15\%. Plaintiffs' expert estimated maximum recoverable damages to be approximately $\$ 133.8$ million (although the expert also said the recoverable damages could be as low as $\$ 7.1$ million given the fact that the Defendant would be likely to vigorously challenge the maximum estimate). ${ }^{37}$

\footnotetext{
${ }^{30} I d$. at 529.

${ }^{31}$ The issue of standing of indirect purchasers claiming for antitrust injury under the laws of the 50 states arose again in Sullivan v. DB Investments, Inc., 2010-1 Trade Cases P 77,090. The Third Circuit vacated the district court's approval of a \$295 million settlement between direct and indirect purchasers of gem-quality diamonds and the De Beers family of companies on the grounds that the class included members from states that bar indirect purchasers from recovering money damages for state law antitrust violations. On August 27, 2010 the court granted plaintiff's petition for rehearing en banc. The case was reargued before the en banc court. [http://www.mmwr.com/home/publications/default.aspx?d=2882]

${ }_{32}^{32}$ Id. at 525-6.

${ }^{33} \mathrm{Id}$. at 526.

${ }^{34} I d$.

${ }^{35} \mathrm{Id}$.

${ }^{36}$ Id. As of June 3, 2002, 48,305 consumer and 1,055 TPP claims had been received and processed by the administrator. Id. at 536 .

${ }^{37} \mathrm{Id}$. at footnote 17.
} 
Class counsel was awarded $22.5 \%$ of the recovery ( $\$ 10.01$ million) between the 27 law firms and the full amount of the requested costs $(\$ 832,382.84){ }^{38}$

The presiding judge at the district court was Judge Sue L. Robinson, appointed by George Bush (Republican). The presiding judges at the Third Circuit were Judge Mansmann, appointed by Ronald Reagan (Republican); Judge Greenberg, appointed by Ronald Reagan (Republican); Judge Barry, appointed by Bill Clinton (Democrat); Judge Fuentes, appointed by Bill Clinton (Democrat); Judge Scirica, appointed by Ronald Reagan (Republican); and Judge Smith, appointed by George W. Bush (Republican).

The litigation did not attract significant media attention or legal scholarship.

${ }^{38}$ In re Warfarin Sodium Antitrust Litigation, 212 F.R.D. 231, 262-3. 
APPENDIX

The following is a list of the cases included in this Study.

1. Meijer, Inc. v. 3M, C.A. No. 04-5871 (E.D. Pa. Aug 14, 2006).

2. In re Air Cargo Shipping Services Antitrust Litig., MD 06-1775JGVVP, 2008 WL 5958061 (E.D.N.Y. Sept. 26, 2008), report and recommendation adopted in part, 06MD-1775(JG)(VVP), 2009 WL 3443405 (E.D.N.Y. Aug. 21, 2009).

3. Sullivan v. DB Investments, Inc., No. 08-2784 et all., 12 (3rd Cir. Dec. 21, 2011)(en banc). Sullivan v. DB Investments, Inc., 667 F.3d 273 (3d Cir. 2011), cert. denied 132 S. Ct. 1876, 182 l. Ed. 2d 646 (U.S. 2012), reh'g denied 132 S.Ct. 2451 (U.S. 2012).

4. In re Elec. Carbon Products Antitrust Litig., 622 F. Supp. 2d 144 (D.N.J. 2007).

5. In re Ethylene Propylene Diene Monomer (EPDM) Antitrust Litig., 681 F. Supp. 2d 141 (D. Conn. 2009).

6. In re High Pressure Laminates Antitrust Litig., 00 MDL 1368 (CLB), 2006 WL 931692 (S.D.N.Y. Apr. 7, 2006).

7. In re Intel Corp. Microprocessor Antitrust Litig., MDL 05-1717-JJF, 2005 WL 1838069 (D. Del. 2007).

8. In re Polyester Staple Antitrust Litig., C.A. No. 3:03-1516 (W.D.N.C. July 19, 2007).

9. Molecular Diagnostics Laboratories v. Hoffmann-La Roche Inc., 402 F. Supp. 2d 276 (D.D.C. 2005).

10. In re Methionine Antitrust Litig., 204 F.R.D. 161 (N.D. Cal. 2001).

11. In re Monosodium Glutamate Antitrust Litig., 2000 U.S. Dist. LEXIS 22521 (D. Minn. Sept. 13, 2000), In re Monosodium Glutamate Antitrust Litig., 205 F.R.D. 229 (D. Minn. 2001).

12. In re Lorazepam \& Clorazepate Antitrust Litig., 205 F.R.D. 369 (D.D.C. Feb. 1, 2002).

13. Novell v. Microsoft (complaint not filed).

14. Ortho Biotech Products, L.P. v. Amgen Inc., CIV. 05-4850 (SRC), 2006 WL 3392939 (D.N.J. Nov. 21, 2006).

15. In re OSB Antitrust Litig., 06-826. 2007 WL 2253419 (E.D. Pa. Aug. 3, 2007).

16. In re Scrap Metal Antitrust Litig., C.A.. No. 01:02-0844 (N.D. Ohio 2002). 
17. Deloach v. Philip Morris Companies, Inc., No. 1:00CV01234, 2004 WL 5508762 (M.D.N.C. Mar. 31, 2005).

18. Teva Pharmaceuticals USA, Inc. v. Abbott Laboratories, 580 F. Supp. 2d 345 (D. Del. 2008).

19. United States v. Visa U.S.A., Inc., 163 F. Supp. 2d 322 (S.D.N.Y. 2011), modified, 183 F. Supp. 2d 613 (S.D.N.Y. 2001), aff'd, 344 F.3d 229 (2d Cir. 2003), aff'd, 344 F.3d 229 (2d Cir. 2003), enforced, 98 CIV. 7076 (BSJ), 2007 WL 1741885 (S.D.N.Y. June 15, 2007).

20. In re Warfarin Sodium Antitrust Litig., 391 F.3d 516 (3d Cir. 2004). 